\title{
1005
}

\section{Bulletin of the Biological Society of Washington No. 1}

\section{A SKETCH \\ OF THE}

NATURAL HISTORY OF THE DISTRICT OF COLUMBIA

TOGETHER WITH

\section{AN INDEXED EDITION}

OF THE

U. S. GEOLOGICAL SURVEY'S 1917 MAP OF WASHINGTON AND VICINITY

\author{
BY \\ W. L. McATEE
}

WASHINGTON, D. C.

MAY, 1918 


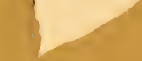


Bulletin of the Biological Society of Washington No. 1

\section{A SKETCH}

OF THE

\section{NATURAL HISTORY OF THE DISTRICT OF COLUMBIA}

TOGETHER WITH

\section{AN INDEXED EDITION \\ OF THE}

U. S. GEOLOGICAL SURVEY'S 1917 MAP OF WASHINGTON AND VICINITY

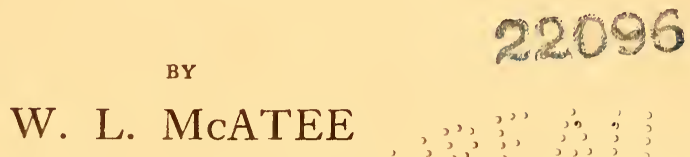

WASHINGTON, D. C.

MAY, 1918 


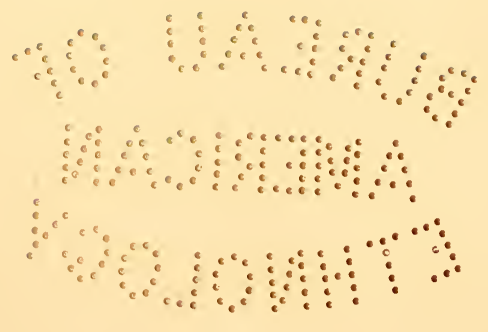

\section{Press of}

H. L. \& J. B. MCQUEEN, INC. Washington, D. C. 
PAGE

Historical sketch . . . . . . . . . . . . . 5

Introduction . . . . . . . . . . . . . 5

Botany . . . . . . . . . . . . 14

Insects . . . . . . . . . . . . . 24

Other invertebrates . . . . . . . . . . 42

Fishes . . . . . . . . . . . . 43

Batrachians and reptiles ........ . . 44

Birds . . . . . . . . . . . . . 46

Mammals . . . . . . . . . . . . 52

Early History of Man in the District . . . . . . 54

Distribution of life in the District of Columbia region . . 57

The Piedmont Plateau and Coastal Plain as faunal and floral provinces . . . . . . . . . 57

Magnolia bogs near Washington, D. C., and their relation to the pine barrens . . . . . . . . 74

Other types of collecting grounds in the District of Columbia region . . . . . . . . . . . 90

Index to the U. S. Geological Survey's 1917 Map of Washington and vicinity . . . . . . . . . . 110

Introduction . . . . . . . . . . . . . 110

Bibliography ............ . . . 112

List of maps used . . . . . . . . . . . 115

Index . . . . . . . . . . . . . . 119

\section{MAPS}

The Piedmont Plateau and the Coastal Plain in the vicinity of the District of Columbia. Page 61, also in pocket inside hack cover.

Washington and Vicinity. U. S. Geological Survey, 1917. Quartered and with index ruling. In pocket inside back cover. 



\section{HISTORICAL SKETCH. ${ }^{1}$}

\section{INTRODUCTION.}

From its proximity to Virginia, one of the first settled regions of the United States, the land from which the District of Columbia was formed would be expected to have received some attention from the early explorers. Not only was the vicinity of the present District explored, but fortunately observations were made upon certain features of the natural history. Romantic expectation is further satisfied by the fact that none other than the redoubtable Captain John Smith made and recorded the first observations ${ }^{2}$ upon the fauna of this neighborhood. We read in "The Third Book of the Proceedings and Accidents of the English Colony in Virginia" ${ }^{3}$ that on "the 16 of June [1608] we fell with the river Patowomek. * * Having gone so high as we could with the bote [this of course means to Little Falls] we met diuers Saluages in Canowes, well loaden with the flesh of Beares, Deere, and other beasts, whereof we had part." Necessarily these "Beares" and "Deere" came from no great distance and must be regarded as part of the District fauna of three hundred years ago. In the narrative of the return royage, Captain Smith mentions "a few Beuers, Otters, Beares, Martins and Minks we found" (op. cit., p. 418).

Thus bears were recorded along the Potomac both above and below the present site of Washington, and there is no doubt that they once roamed over all the territory now

\footnotetext{
1 Read at the 556 th meeting of the Biological Society of Washington, May 6, 1916.

${ }^{2}$ Such books as "A briefe and true report of the new found land of Virginia * * *", by Thomas Harriot, 1588; "The historie of travaile into Virginia Brittania * * *", written by William Strachey, 1611, published 1849; "* * * An account of several observables in Virginia * * *", written by John Clayton, 1688, published 1694-5 ; "Notes on the State of Virginia * * *", written by Thomas Jefferson, 1781-2, published 1782, and others while containing information on the natural history of Virginia do not relate in any way to the region of the District of Columbia.

${ }^{3}$ Works. Edited by Edward Arber, 1884, p. 417.
} 
included in the District. The pine marten is not usually recognized as a member of the District Fauna, but according to Wm. Palmer, there is a fairly certain record as late as about 1880 ; Smith's statement therefore probably is correct.

Larger game is mentioned by the next contributor to the natural history of the District, an account of whose experience is quoted from Wm. T. Hornaday:

"The earliest discovery of the bison in Eastern North America, or indeed anywhere north of Coronado's route, was made somewhere near Washington, District of Columbia, in 1612, by an English navigator named Samuell Argoll, ${ }^{4}$ and narrated as follows: 'As soon as I had unladen this corne, I set my men to the felling of Timber, for the building of a Frigat, which I had left half finished at Point Comfort, the 19. of March: and returned myself with the ship into Pembrook [Potomac] River, and so discovered to the head of it, which is about 65. leagues into the Land, and navigable for any ship. And then marching into the Countrie, I found great store of Cattle as big as Kine, of which the Indians that were my guides killed a couple, which we found to be very good and wholesome meate, and are very easie to be killed, in regard they are heavy, slow, and not so wild as other beasts of the wildernesse.'

"It is to be regretted that the narrative of the explorer affords no clew to the precise locality of this interesting discovery, but since it is doubtful that the mariner journeyed vely far on foot from the head of navigation of the Potomac, it seems highly probable that the first American bison seen by Europeans, other than the Spaniards, was found within 15 miles, or even less, of the capital of the United States, and possibly within the District of Columbia itself." 5

An inducement for the early explorers to visit our region was the considerable Indian population. The country about the juncture of the Potomac and Anacostia rivers, especially,

\footnotetext{
4 Purchas: His Pilgrimes. (1625), Vol. IV, p. 1765. "A letter of Sir Samuel Argoll touching his Voyage to Virginia, and actions there. Written to Master Nicholas Hawes, June, 1613."

5 Hornaday, Wm. T. The Extermination of the American Bison. Rep. U. S. Nat. Museum, 1886-7, (1889), p. 375 .
} 
was thickly settled and the waters there were favorite fishing resorts. The Indian village Nacostines (Anacostia) is specifically mentioned by Henry Fleet who visited it in June, 1632 , and obtained "800 weight of beaver." This is good evidence of the abundance at that time of these animals in country easily reached from Anacostia. Collateral evidence is afforded by the name Beaver Dam Branch still applied to a stream flowing into Eastern Branch through the town of Benning.

Fleet, like the travellers previously mentioned, also ascended to Little Falls. He describes ${ }^{6}$ the trip as follows: "On Monday the 25th of June, we set sail for the town of Tohoga, when we came to anchor two leagues short of the falls, being in latitude of 41 , on the 26th of June [1632]. This place without all question is the most pleasant and healthful place in all this country, and most convenient for habitation, the air temperate in summer and not violent in winter. It aboundeth with all manner of fish. The Indians in one night commonly will catch thirty sturgeons in a place where the river is not above twelve fathoms broad. And as for deer, buffaloes, bears, turkeys, the woods do swarm with them, and the soil is exceedingly fertile, but above this place the country is rocky and mountainous like Cannida." (p. 228.)

Apparently none of the other early travellers recorded anything on the natural history of this region until Andrew Burnaby, whose visit was in 1759 but whose account of it was not published until 1775 . He visited Mount Vernon in October, 1759 , and in his reference to the event describes fish hawks capturing their prey and being robbed of it by the bald eagle. Shortly after describing the Potomac River, he says, ${ }^{\top}$ eridently speaking of Virginia in general:

"The forests abound with plenty of game of various kinds; hares, turkies, pheasants, woodcocks and partridges, are in (p. 9) the greatest abundance. In the mashes are found

\footnotetext{
6 Fleet, Henry. A brief journal of a voyage made in the bark "Warwick" to Virginia and other parts of the continent of America.

Printed in Neill, E. D. The English Colonization of America during the Seventeenth Century. London, 1871, pp. 221-237.

${ }^{7}$ Burnaby, Andrew. Travels through the Middle Settlements in North America in the years 1759 and 1760. London, 1775, $106 \mathrm{pp}$.
} 
soruses, a particular species of bird, more exquisitely delicious than the ortolan, snipes also and ducks of various kinds. The American shell drake and bluewing exceed all of the duck kind whatsoever; and these are in prodigious numbers. In the woods there are variety of birds remarkable both for singing and for beauty; of which are the . mocking-bird, the red-bird or nightingale, the blue-bird, the yellow-bird, the humming-bird, the Baltimore-bird, the summer-duck, the turtle, and several other sorts.

"Reptiles and insects are almost innumerable; some of them, indeed are harmless and beautiful, such as the blacksnake, the head-snake, the garter-snake, the fire-fly, and several sorts of butterflies; but the rattle-snake and viper, and many others are exceedingly venemous and deadly." [A footnote mentions the bull-frog and a small green frog which sits upon the boughs of trees.] "Of quadrupeds there are various kinds; squirrels of four or five different species" (p. 10) [a footnote, pp. 10-11, inentions the ground and flying-squirrels, and the polecat or skunk], "opposums, racoons, foxes, beavers, and deer; and in the desorts and uninhabited parts, wolves, bears, panthers, elks or moose-deer, buffaloes, mountain-cats, and various other sorts." (p. 11.)

Many definite observations on the natural history of the District are recorded in a charming little book published in Paris in 1816. It has the rather forbidding title of "A chorographical and statistical description of the District of Columbia," ${ }^{8}$ but the contents are enlivened by shrewd comment on social customs of that day and enriched by informing references to many plants and animals. The author is David Baillie Warden who was upon consular duty in Washington. He dedicated his book to Mrs. Custis, who we are informed in the introduction accompanied him on some of his excursions. He regrets "that the difficulty of communication has prevented me from procuring other specimens of the birds and insects of this District, which would have enabled me to complete the nomenclature of objects of natural history.

${ }^{8}$ Interesting additions to this account by the same author are contained in chapter 34, "Columbia Territory, and the City of Washington," in Vol. 3 , of "A Statistical, Political and Historical Account of the United States of North America," 1819, pp. 182-219. 
It will give me pleasure," he continues, "to see this deficiency supplied by another, and the errors, into which I may have fallen, corrected with the same spirit which guided my researches." (p. vii.)

Some of Mr. Warden's pages are exceedingly interesting. His account of Great Falls is as follows:

"The distance from Washington to the falls of the Potomac in the Virginia side is about twenty miles. By the bridge, above Georgetown, near the Little-Falls, it was five miles shorter; but some years ago this bridge was destroyed by the pressure of accumulated ice and water after a sudden thaw, and has not been since repaired. The wild and romantic scenery of the Great Falls, which are seen most to advantage from the Virginia ( $p .11$ ) side is scarcely to be equalled. There is a stupendous projecting rock covered with cedar, where one may sit and gaze at the waters dashing with impetuosity over the rugged surface. At the close of winter vast masses of ice, rolling over the rocks with hideous crash, present a scene truly sublime.

“* * * Several delicious springs issue from a neighboring hill, which commands an enchanting prospect. The trees which abound here most are willow, birch, cedar, and oaks, of different species. The yellow jessamine ${ }^{9}$ is of a prodigious size. The prickly pear ${ }^{10}$ grows on the banks of the canal. White hore-hound ${ }^{11}$ and sweet-fennel, ${ }^{12}$ of which there is great plenty, are employed by the inhabitants for medicinal drinks. The odour (p. 12) of aromatic plants seems to be much stronger here than in the Low-Lands. Of wild cherries and strawberries there is great abundance. The banks of the river are infested by different species of snakes, particularly of black, ${ }^{13}$ rattle, ${ }^{14}$ and copper-head snakes." ${ }^{15}$ (p. 13.)

Mr. Warden evidently spent some time upon Analostan Island, and his notes form a fairly complete sketch of its natural history. At any rate they are far more than has

- Bignonia radicans

${ }^{10}$ Cactus Opuntia.

11 Marrubium vulgare.

12 Faeniculum dulce.
13 Coluber constrictor.

${ }^{14}$ Crotalus horridus.

${ }_{15}$ Coluber erythogaster. 
since been written on the place. The comment upon animals is quoted:

"This island is the resort of various reptiles. We found the nest of the terrapin (Testudo concentrica, or concentric tortoise), or fresh-water turtle, in the garden at the distance of about thirty feet from the water, containing nineteen eggs, laid close to each other, and the interstices filled with earth. The greater circumference of the egg was four inches and half; the lesser, three. The nest, or hole, was of an oval form, and four inches in depth. The eggs of this species are deposited from the first of June to the middle of July. Before the turtle commences the formation of the hole for her eggs, she urines on the spot, then scrapes out a little earth, again urines, and thus continues until the operation is finished. I saw another nest, from which the turtle was taken at the moment when she had placed herself in an almost erect position to deposit her eggs, which she always performs during the day, and it is said, never returns to the spot. The young ones are hatched by the heat of the sun, and are (p. 144) supposed to remain in the nest till spring. Several persons, whom I consulted on this subject, assured me that they have turned them up with the plough at this season. The turtle, when shaken before she lays her eggs, makes a hollow noise, as if she contained water. One in this state weighed six pounds, which, it appears, is the common size. The species known by the name of the terrapin is very shy, and ceases to walk as soon as it sees a person approach near it. When endeavoring to escape, it runs nearly as fast as a duck. The blacks make soup and eat the eggs of this species, of which they are very fond.

"The snapping turtle (Testudo ferox) is also seen in the waters of this river, some of which weigh from forty to fifty pounds, and lay forty or fifty eggs. General Mason, some years ago, caught one of a huge size which he threw into his canoe, and it attacked him so furiously therein that he was obliged to leap into the water. The reptile followed, and thus made its escape. Its bite is severe and dangerous. Two species of fresh-water tortoise inhabit (p. 145) the island; namely, the painted tortoise, Emys picta or Testudo picta, and the streaked tortoise, Emys virgulata. 
"The head of the painted turtle manifested symptoms of life two hours after decapitation. Three cherry stones were found in the stomach. It is said that small snails are its daily food. This species is not eaten. The musk-rat (Castor zibethicus) inhabits the banks of this island. The surface being now cleared, there is no place for its habitation, which was formerly constructed of vegetable substances, in the midst of the reeds of a marsh, and was generally five or six feet in height, and as many in breadth. The family reposed in a dry and neat apartment above the surface of the water, into which they descended when attacked, and retreated by a subterraneous passage to a neighbouring stream. If the family were numerous, there were three such passages; if otherwise, one or two only. A method of taking them, practiced by the savages, was to discover and intercept this communication, by means of knots of twisted grass. The animal then returned to the water under its abode, where forced to seek air, it showed its head, and was struck dead with a stick or club. The muskrat abounds in the swamp (p. 147) adjoining the Potomac bridge, and is killed by the blacks in a curious manner. A square board, bearing a considerable weight of stones or mud, is placed in an inclined position, and is supported by three sticks in a particular manner. Parsnips are put underneath, of which the rats are very fond; while devouring them, they necessarily move one of these sticks, by which the board suddenly falls, and crushes them to death. The skin sells at twenty-five cents.

"The deer, wild turkey, canvas.back duck (supposed to be the Anas ferina of Linnaeus, or mildorin of Buffon), the wiid goose, which inhabited this place about fifty years ago, have all disappeared. This species of duck, so delicious to the taste, was then sold for sixpence.

"The following method was formerly employed to kill the wild goose (Anser canadensis). This bird, shy and cunning, feeds in the midst of a plain or open field, and forms a regular line, at the extremity of which is placed a centinel, to give warning in case of danger, which, if remote, is indicated by a certain position of (p. 148) the head, and if imminent, by a certain cry. The sportsman, by means of a 
docile horse, which concealed him from the view, approached slowly, until he brought them within the reach of his gun.

"By an act of 1730, the shooting of deer was prohibited from the first of January to the first of August. The penalty was four hundred pounds of tobacco. By other acts of 1728 , any master, mistress, owner of a family, or single taxable person, was obliged to produce yearly, to the justice of the county, three squirrel-scalps, or crows' heads. The penalty in this case was three pounds of tobacco. A premium of two pounds was given for every scalp more than three. The reward for a wolf's head was two hundred pounds.

"Annalostan Island abounds with birds of various kinds. The catbird (Musicapa vertice nigra-Catesby) is almost tame. When its nest is in danger, it makes a loud noise, and seems as if it would tear the face of the person who approached it. We saw in the garden a partridge nest, containing nineteen eggs. The humming-bird (Trochilus colubris) frequents (p. 149) this place. When caught, it feigns death, like the opossum (Didelphis opossum), and, by this means, escapes from the hand. We saw one thus escape from the pretty hand of Mrs. B-e.

"The mocking-bird (Turdus polyglottus) does not frequent this island, though it is seen on the adjacent borders of the river. Perhaps it has been expelled by the crow black-bird (Gracula quiscula), its natural enemy, which swarms in this place. It is a pity that so enchanting a spot is deprived of the notes of this inimitable songster." (p. 150.)

Mr. Warden's observations on the method used by the terrapin to soften the earth before digging, and on the humming bird feigning death are highly original and his mention of food found in the stomach of the painted terrapin undoubtedly is the first record of the food of this reptile based on scientific investigation. Besides the scattering natural history notes in Mr. Warden's book, the volume contains also the first formal lists of plants (142 species) of the District of Columbia, of birds (32 species), and of a group of insects ( 5 species of butterflies) that ever were published. Mr. Warden's book thus marks the beginning of scientific description of our natural history. 
Some of the forerunners of what is now called the Washington Guide contained interesting comment on the natural history of the District. This is especially true of two which will be briefly reviewed. The first, published by Jonathan Elliot in 1830, is entitled "Historical Sketches of the Ten Miles Square forming the District of Columbia * * * also a description of the River Potomac-its fish and wild fowl, etc." "The waters of the Potomac," this writer says, "are frequented by a great variety of the finest wild fowl. Among the most rare and valuable are the canvass back duck, by some called white-backs. Myriads of them during the winter literally darken the stream of the river." * * * He adds comment astonishing to the present day epicure: "The average price of canvas backs in Washington is about 75 cents, but they are frequently sold at 50 cents per pair." (p. 60.) Other interesting comment on the prices of that time relate to the shad. "In the height of the season a single shad weighing from 6 to 8 pounds is sold in the market of the District for 6 cents, and by the hundred for from 3 to 4 dollars" (p. 428).

Mr. Elliot gives many details relating to birds and fishes, of which we will cite only one anecdote relating to a fish. He comments upon the leaping habits of sturgeon, some of which he says weigh 150 pounds. One of these large sturgeon leaped into a ferry boat at Georgetown during the Revolutionary War, coming down on the lap of an American officer with such violence as to break his thigh, the injury later resulting in death.

In $18011^{16}$ was published "Philp's Washington Described," edited by William D. Haley, in which are annotated skeleton lists of the vertebrates and molluses of the District with interesting comment on the insects and plants. The editor states his obligations to Baron Osten Sacken, Professors

\footnotetext{
16 From the Bulletin of the Proceedings of the National Institution for the Promotion of Science we learn that at the meeting of August 10, 1840, "the Department of Natural History was requested to prepare catalogues of the Animals and Vegetables of the District of Columbia" (Bul. I, No. 1, June-December 1840 (1841), p. 7). At the meeting of November 9, the same year, a manuscript entitled "Fauna Columbiana," by Dr. T. B. J. Frye, was presented (ibid. p. 10), but it was never published and it cannot now be found.
} 
Henry, Baird, Ford, Gill, Ulke, and Jillson and Doctors Gale, Force and Foreman, and it is evident that his remarks on natural history were gathered from authentic sources. The scientific names are used with such precision that it is probable the proof was read by someone of scientific ability. Coues and Prentiss refer to the work in the following language: "A little book entitled 'Washington Described,' * * * contained cursory notices of the natural history of the District, prepared anonymously by several of the resident naturalists; and among these was a slight sketch of the Ornithology by one of the present writers." 17

It seems probable, therefore, that we can accept the natural history statements at their face value. The following species not recorded from the District in subsequent publications are mentioned by Haley: Among mammals, Peromyscus nuttallii, a species at present known from no nearel locality than Dismal Swamp, Va.; among birds the white ibis, a notorious wanderer like others of the heron tribe; and among reptiles Lampropeltis doliata clerica, adding a fourth to the varieties of this species of snake known to inhabit the District. With these interesting records is closed the introduction of the sketch of the natural history of the District of Columbia. We will now review what has been accomplished in the various branches of the subject, and first of all in botany.

\section{BOTANY.}

'The first scientific paper thus far brought to light which mentions a plant possibly obtained within the limits of the District of Columbia flora is entitled "Remarks by Mr. James Petiver, Apothecary and Fellow of the Royal Society, on some Animals, Plants, etc., sent to him from Maryland, by the Reverend Mr. Hugh Jones," 18 and it was published in the Philosophical Transactions of the Royal Society of London in November, 1698.

Under the heading "Aconitum baccis niveis et rubris.

17 Avifauna Columbiana. Bul. 26, U. S. Nat. Mus., 1883, p. 8.

18 Philosophical transactions. Roy. Soc. of London, Vol. XX, No. 246, Nov., 1698, pp. (393)-(406). 
Corn. 76, Raii H. Pl. 662," is the statement: "Mr. Fisher, a friend of mine, brought me this root from Potuxen River in Maryland, and he tells me, they there call it, Rich-Root, and use it as a specifick against the Scurvy; they boyl about a pound of it in two gal- [p. 403] lons of cyder, till but two quarts remain, and being strained, they drink half a pint of it every morning, either alone, or mixt with any other drink. He assured me it cured him, and several other in the same ship he came from thence in." (p. 404.)

This statement leares us in some doubt as to whether this concoction really had medicinal effect or whether like certain more modern compounds it was merely a variant of the cup that cheers. There is little doubt, however, that the plant mentioned is the white baneberry (Actaea alba), a species not now included in the District list.

The next specific mention of a plant from the region of the District Flora appears to be that of Gronovius in the Flora Virginica of 1762 . This flora based on material collected by Dr. John Clayton, and a large part of the original matter in which, consists of Clayton's notes, might better be known as Clayton's Flora Virginica. However that may be, it suffices for the present purpose to note that "Betula foliis rhombeo-ovatis, acuminatis duplicato-serratis" is recorded as occurring not far to the westward of the cataracts of the river Potomac. ${ }^{19}$ In modern nomenclature this plant is the common river birch (Betula nigra), one so abundant and widespread that specific notes on distribution seem superfluous. It may be that records of this or other plants from our region are in the 1739 and 1743 parts of the Flora virginica, but these have not been available.

Search of Nuttall's "Sylva," Pursh's "Flora," and the Michauxs' "Flora," and "Sylva" have revealed no definite records of plants from the vicinity of the District. This is rather surprising since all of these botanists visited the locality and Nuttall worked in Washington for some time upon the collections of the National Institute. The visit of André Michaux is recorded in Washington's diary for

10 Gronovius, J. F.-Flora virginica exhibens plantas quas nobillissimus vir D. D. Johannes Claytonus, Med. Doct., etc., etc., in Virginia crescentes, observavit, et obtulit, 1762 , p. 146. 
June 19, 1786, the entry being: "A Mons. André Michaux, a botanist sent by the court of France to America, visited, dined and returned to New York whence he had come." Certain subsequent entries relate to plants presented by Michaux and set out in the grounds at Mount Vernon.

'The first 20 formal list of plants of the District of Columbia appeared in David Baillie Warden's "Chorographical and Statistical Description of the District of Columbia" published in Paris in 1816. The list is entitled Florula Columbiana, etc. (see bibliography) and contains 142 species identified by the celebrated botanist, Joseph Correa de Serra, Ambassador from Portugal to the United States.

Organized study of the plants of the District of Columbia began in 1817 with the formation of the Washington Botanical Society, March 20. 'The society had 13 charter members and added 7 later. The District was divided into four regions which were assigned to committees of members for study. The society was vigorously active until 1820 , much less so in succeeding years and held a final meeting at which it adjourned sine die March 27, 1826.

The results of its labors were a check list published in 18i9, the Forula Columbiensis, containing names of 296 plants; a fuller list, the Florula Columbiana, published in the Washington Guide in 182.2 and mentioning 460 species; and the Florae Columbianae Prodromus of 1830 listing 912 species. The first was anonymous, and the last two appeared under the name of Dr. John A. Brereton. There is no doubt, however, that they are founded upon the entire herbarium of the Botanical Society to which Dr. Brereton contributed no more than certain other individuals.

The next considerable wave of botanical activity in the District was due to the Potomac-Side Naturalists Club. This organization founded in 1858, languished during the

${ }^{20}$ Rafinesque informs us (Rafinesque, C. S. Circular address on Botany and Zoology, followed by the Prospectus of Two Periodical Works; Annals of Nature and Somiology of North America. Philadelphia, 1816, page 12) that he prepared a Florula Columbica, or catalogue of the plants found in the District of Columbia, 1804, which he gave Dr. B. S. Barton for insertion in The Philadelphia Medical and Physical Journal. Dr. Barton acknowledged (op. cit. II, 1806, p. 177) this to be a fact and promised to publish the catalogue with additions-a forecast never fulfilled. 
period from 1866 to 1873 , when it was reorganized. In 1874 a committee was appointed to prepare a new catalog of the flora of the District, the members being Dr. George Vasey, Prof. J. W. Chickering, Dr. E. Foreman, Prof. Wm. H. Seaman, and Mr. L. F. Ward. Their revised list of 1083 species-The Flora Columbiana-was published in Field and Forest, the official organ of the Club, from April to December, 1876. A supplement containing 112 additional species was published in 1878. Meanwhile one member of the Committee, L. F. Ward, pushed ahead independently, and in 1882 published a Guide to the Flora of Washington and Vicinity. It contained an important introductory chapter describing local collecting grourds, the flowering seasons, and containing statistics of the contents of the list and comparisons with other lists. It included also an appendix on plant collecting and making a herbarium, and a check list. All of these special features were separately published. One thousand two hundred and forty-nine species of vascular plants were listed. Six lists of additions have been published, appearing in 1884, 1886, 1892, 1896, April, 1901, and June, 1901.

A share of the credit for these supplemental lists belongs to the Botanical Seminar founded in 1893 and the Washington Botanical Club organized in 1898. These were merged in 1901 to form the Botanical Society of Washington.

In 1906 a typewritten list of the vascular plants of the District of Columbia was prepared for the use of the Society. It contains 1,598 species and has been used for some years as a foundation upon which to build a more pretentious work on the District Flora. This paper now in manuscript includes keys, brief descriptions and notes on distribution.

\section{BIBLIOGRAPHY.}

Warden, David Baillie.

Florula Columbiana, Sive enumeratio Plantarum in Territorio Columbiae sponte nascentium; or Catalogue of the plants, shrubs and trees which grow spontaneously in the District of Columbia.

In "A Chorographical and Statistical Description of the District of Columbia, the seat of the general Government of the United 
States, with an engraved plan of the District, and view of the Capitol. Paris, 1816, pp. 191-209.

Lists 142 species including introduced and cultivated forms.

Washington Botanical Society.

"Florula Columbiensis: or a list of plants found in the District of Columbia; arranged according to the Linnaean system, under their respective classes and orders, etc., and exhibiting their generally received common names, and time of flowering, during the years 1817 and 1818. Washington: printed for the Washington Botanical Society by Jacob Gideon, Jun., 1819."

The work is a 14-page pamphlet giving a bare list of the technical and popular names of 296 species of flowering plants with the date of their observation in 1817 and 1818. It apparently was intended as a working list for the members of the Society. ${ }^{21}$

Brereton, J. A.

Botany of the District of Columbia, pp. 123-138. Heading Florula Columbiana on p. 124. In Elliot, Wm., the Washington Guide, containing *** Botany of the District of Columbia, Nov., 1822.

460 species listed. Exactly the same in Second Edition, 1826, and Second Edition with corrections and additions, 1830 . In the "improved edition," 1837, the botany occupies pp. 295-310, and the preface states that it has been "revised and corrected by Mr. Rich from the records of the Botanical Society of this place." However, the number of species remains the same, and the changes, if any, are insignificant.

Florae Columbianae Prodromus exhibens Enumerationem Plantarum Quae Hactenus Exploratae Sunt, or a prodromus of the Flora Columbiana exhibiting a list of all the plants which have as yet been collected. (1830) cover date 1831. $86 \mathrm{pp}$.

"During the spring of 1825 , after the dissolution of the late Washington Botanical Society, a few gentlemen of the city devoted to Botany formed an association to explore and investigate de novo the indigenous plants of the District of Columbia. The association, under the name of 'The Botanic Club,' consisted of Wm. Mechlin, Wm. Rich, Alex. McWilliams, and the compiler, and in the following year of James W. Robbins, M. D." The results of their labors are embodied in the "Prodromus," which lists 912 species of plants.

Gale, L. D.

On the Oaks of the District of Columbia.

Proc. Nat. Institute, N. S. Vol. I, No. 2 (1855-6), pp. 67-68, 2 figs.

Read Nov. 21, 1853. Presented for publication May 21, 1855.

Mentions 12 indigenous and 2 introduced species and gives notes on Bartram's oak (Quercus heterophylla) and on dates of flowering.

\footnotetext{
${ }^{21}$ Quoted from Coville, F. V. Records of the Columbia Historical So-
} ciety, Vol. 5, 1902, p. 189. 
Vasey, George.

Exotic Trees in Washington.

Field and Forest, Vol. I, Nos. 3-4, Aug.-Sept., 1875, pp. 17-19.

20 species mentioned.

Rare and Noteworthy Trees in Washington.

Field and Forest, Vol. I, Nos. 5-6, Oct.-Nov., 1875, pp. 33-37.

About 52 species of ornamental trees native to the U. S., and a few foreign ones are mentioned.

Ward, Lester F.

Oaks of the Potomac Side.

Field and Forest, Vol. I, Nos. 5-6, Oct.-Nov., 1875, pp. 39-42.

11 species, 3 varieties, 6 hybrids listed.

(Committee.)

Flora Columbiana. A catalogue of the plants growing without cultivation in the District of Columbia.

Field and Forest, Vol. I, Nos. 10-11, March-April, 1876, pp. 83-87.

II, No. 1, July, 1876, pp. 13-15.

II, No. 2, Aug., 1876, pp. 31-33.

II, No. 3 , Sept., 1876 , pp. $45-46$.

II, No. 4 , Oct., 1876, pp. 61-64.

II, No. 5 , Nov., 1876 , pp. $86-88$.

II, No. 6 , Dec., 1876, pp. 103-105.

1,083 species.

Seaman, Wm. H.

Edible Fungi.

Field and Forest, Vol. I, Nos. 8-9, Jan.-Feb., 1876, p. 71.

27 species.

Oldberg, Rudolph.

Mosses of the District of Columbia.

Field and Forest, Vol. II, No. 7, Jan., 1877, pp. 118-120.

Musci, 97 species; Hepaticae, $29-126$ in all.

\section{(Committee.)}

Addenda to Flora Columbiana. Made during 1877.

Field and Forest, Vol. 3, No. 9, Mar., 1878, p. 145; Vol. III, Nos.

10-11-12, April-May-June, 1878, p. 164.

112 species. 
Ward, Lester F.

Field and Closet Notes on the Flora of Washington and Vicinity. (Abstract.)

Bul. Philos. Soc. Wash. iv, 1881, pp. 64-119. Reprinted with explanatory notes in Glimpses of the Cosmos, Vol. II, 1913, pp. 360.425.

Practically the same as the introduction to his Guide to the Flora of Washington.

Guide to the Flora of Washington and Vicinity.

Bul. 21, U. S. Natl. Museum, 1881, 264 pp., 1 map.

A comprehensive local flora, listing 1,249 vascular plants and 131 cryptogams. A history of the making of this list is contained in Glimpses of the Cosmos, Vol. II, 1913, pp. 448-464.

Check list of the Flora of Washington, D. C., and Vicinity.

From Bul. U. S. National Museum, No. 22, 1882, pp. 148-207.

A reprint with same pagination of the check-list in the Guide to the Flora of Washington.

List of Plants added to the Flora of Washington from April 1, 1882, to April 1, 1884.

Proc. Biol. Soc. Wash., Vol. II, pp. 84-87, April 10, 1884.

41 additions and a few corrections.

Knowlton, F. H.

Additions to the Flora of Washington and Vicinity from April 1, 1884, to April 1, 1886.

Proc. Biol. Soc. Wash., Vol. III, pp. 106-110, 1886.

35 additions, besides 4 oak hybrids, here first catalogued.

"Changes in nomenclature," pp. 127-129. "New localities for rare species,” pp. 129-132; “Species excluded,” p. 132.

Lehnert, E.

A revision of the musci and hepaticae of Washington and vicinity with numerous additions.

Proc. Biol. Soc. Wash., Vol. III, pp. 110-118, 1886.

Containing 238 species, which is 111 in addition to the Oldverg list.

A list of the Lichens of Washington and Vicinity.

Proc. Biol. Soc. Wash., Vol. III, pp. 118-127, 1886.

251 species.

Baker, Frank.

Native Trees of the National Zoological Park.

Ann. Rep. Smiths. Inst. (1890), 1891, pp. 65-66.

46 species. 
Hunter, W.

Botany of the Zoological Park.

Arin. Rep. Smiths. Inst. (1890), 1891, pp. 68-72.

About 350 species listed.

Sudworth, Geo. B.

Trees of Washington, D. C. (cover title).

Arborescent Flora (native and cultivated) of Washington.

Forestry Division, 1891.16 pp., 2 maps.

Lists separately and locates on maps the trees in the Department of Agriculture and White House grounds, and in Lafayette Square. Includes 324 species (exclusive of varieties), of which 90 (one doubtfully) are said to be indigenous to the District of Columbia.

Holm, Theodor.

Third List of Additions to the Flora of Washington, D. C.

Proc. Biol. Soc. Wash., Vol. VII, pp. 105-132, June 10, 1892.

75 additional species besides 2 oak hybrids.

Fourth List of Additions to the Flora of Washington, D. C. Proc. Biol. Soc. Wash., Vol. X, pp. 29-43, Feb. 26, 1896.

28 additional species.

Ridgway, Robert.

Additional notes on the native trees of the lower Wabash Valley.

Proc. U. S. Nat. Mus. 17, 1884, pp. 409-42, Pls. 10-15.

This paper includes for comparative purposes a list of 28 species of trees formed on a 200-acre farm near Falls Church, Va., and a list of 47 species observed on a tract of 5 square miles near Laurel, Md. (pp. 417-418).

Greene, E. L.

Remarks on ascaulescent violets.

Pittonia, 3, pp. 139-145, Dec. 16, 1896.

Notes on 6 species occurring about the District region.

Studies in the Compositae, 2. Some northern species of Antennaria.

Pittonia, 3, pp. 273-288, March 21, 1898.

Three species from vicinity of $D$. C.

Critical notes on Antennaria.

Pittonia, 3, pp. 318-323, May 7, 1898.

Four species of D. C. region discussed.

Two new Gerardias.

Pittonia, 4, pp. 51-52, Pls. 9-10, April 11, 1899.

From D. C. 
Miller, G. S., Jr.

The dogbanes of the District of Columbia.

Proc. Biol. Soc. Wash., 13, pp. 79-90, P1. II, Sept. 28, 1899.

Synopsis of 7 species, 3 of them described as new.

Greene, E. L.

Studies in the Compositae, 8.

Pittonia, 4, pp. 243-284, Jan. 26, 1901.

Describes 2 new species of Bidens from this region.

Holm, Theodor.

Fifth List of Additions to the Flora of Washington, D. C. Proc. Biol. Soc. Wash., Vol. XIV, pp. 7-22, April 2, 1901.

41 additions.

Steele, Edward S.

Sixth List of Additions to the Flora of Washington, D. C., and Vicinity.

Proc. Biol. Soc. Wash., Vol. XIV, pp. 47-86, June 19, 1901.

With descriptions of new species and varieties by Edward L. Greene, Alvah A. Eaton, and the Author.

151 additions; many are new varieties only; original descriptions of 3 forms.

Greene, E. L.

New or noteworthy violets.

Pittonia, 5, pp. 87-106, Nov., 1902.

5 new species from the District flora.

Miller, G. S., Jr.

The species of Geum occurring near Washington.

Proc. Biol. Soc. Wash., 17, p. 101, April 9, 1904.

Four species recorded; correction of previous record of a fifth.

Brainerd, Ezra.

Hybridism in the genus Viola-III.

Rhodora, 8, pp. 49-61, Pls. 66-70, March, 1906.

Notes on 7 hybrids from the Washington region.

Burgess, E. S.

Species and Variations of Biotian Asters with discussion of variability in Aster.

Mem. Torrey Botanical Club, 13, 1906, 419 pp., 108 figs.

Records 24 species and 5 varieties from District of Columbia Region, many of them new. 
Greene, E. L.

New species of Viola.

Leaflets of Botanical Observation and Criticism, 1, pp. 214-219, June 5, 1906.

5 new species and 2 new varieties from the vicinity of Washington, D. C.

House, H. D.

Violets of the District of Columbia.

Rhodora, Vol. 8, July, 1906, pp. 117-122, Pls. 71-72.

A list of 26 species and 19 hybrids.

Ricker, P. L., Chairman of Seminar.

A list of the Vascular Plants of the District of Columbia and vicinity, prepared for the use of the Botanical Society of Washington, 133 pp., 1906.

A typewritten working list containing 1,598 species exclusive of hybrids and varieties.

Tidestrom, Ivar.

Eiysium Marianum. First ed. Pt. 1, Ferns and Fern allies, pp. 1-63, Pls. 1-8 (bis.), 1906. Second ed., Pt. 1, Ferns and Fern Allies, pp. 1-63, Pls. 1-8 (bis.). Pt. 2, Evergreens, pp. 67-96, Pls. 10-12, 1908, Pt. 3, Salicaceae, Ceriferae, Betulaceae, pp. 1-60, Pls. 1-14, 1910.

Shreve, F., Chrysler, M. A., Blodgett, F. H., and Besley, F. W.

The Plant Life of Maryland.

Special Publ. Md. Weather Service, Vol. III, 533 pp., 38 Pls., 1910. Contains many references to plants of the vicinity of the District of Columbia.

Tidestrom, Ivar.

Notes on the flora of Maryland and Virginia.

lihodora, 15, pp. 101-106, June, 1913.

On 4 species of pines in the District flora.

Greene, E. L.

New species of Ranunculus.

American Midland Nat., 3, No. 12, Nov., 1914, pp. 333-5.

Four new species, 2 of them from this region.

Violets of the District of Columbia, 1.

Cybele Columbiana, Vol. 1, No. 1, Dec., 1914, pp. 7-33.

An important discussion of the habitats and relationships of numerous violets of this region.

Bartlett, $\mathrm{H} \mathrm{H}$.

Twelve elementary species of Onagra.

Cybele Columbiana, Vol. I, No. 1, Dec., 1914, pp. 37-56, Pls. 1-5.

Four new forms from Washington. 


\section{INSECTS.}

The first general natural historian of the District of Columbia-Warden-does not fail to pay some attention to insects. In fact he published the first local list for the region, it being the following: ${ }^{22}$

"Of our collection of insects, there remain in a state of preservation but five species of the genus Papilio, or butterfly, which, however, are the most common in this District.

Papilio cardui (Fabr.)

Papilio plexippus (Cram.)

Papilio polydamos (Cram.)

Papilio astinous (Cram.)

Papilio Tyrrhea (Fabr.)"

None of these species are now considered to belong to the genus Papilio. Evidently Warden had collected a number of insects belonging to other groups, but like many entomologists of later times had his plans spoiled by mishaps to his specimens.

One of Warden's popular notes on insects is of interest, but it should be explained that the first creature he namesthe wood-louse-is not really an insect. He says: "Two insects abound in this place, and torment the lovers of nature; the wood-louse (Acarus Americanus, L.-A species of Zecca) (p. 167) and mosquito (Culex pipiens, L.). The former nearly the size of a common louse, conceals itself under the skin and clings closely to the flesh from which it is not easily extricated. Its colour is reddish, which becomes paler when the insect is satiated with blood. The bite excites considerable inflammation, and, in the eye, or ear, might be attended with dangerous consequences. The bite of the mosquito also creates inflammation, and it annoys the ear of the pensive or studious by its unpleasant buzz." (p. 168.)

Progressive movements depend upon individuals and seldom is this aphorism better illustrated than in the history of the study of Entomology in the District of Columbia. With the exception of the above quoted Warden notes of

${ }^{22}$ Warden, D. B. A chorographical and statistical $\overline{\text { description of the }}$ District of Columbia, Paris, 1816, p. 212. 
1816, up to the rear 1859 apparently not an insect was recorded from the District and none had ever been originally described from the area. Then began the work of Baron Charles Robert von den Osten Sacken and those whom he interested and assisted, which laid such a splendid foundation for the study of certain groups not only for the District but for the United States.

Baron Osten Sacken was secretary to the Russian legation from 1856 to 1862 and visited Washington from time to time up to the year 1877. In 1859, as indicated above, he published his first paper relating to the insect fauna of the District, and a splendid one it was. It dealt with the smaller crane-flies, of which 46 species were recorded from the District of Columbia. All but four of these are new species, and 16 of them have the District as the sole place of capture, thus unquestionably making it their type locality. Osten Sacken was an indefatigable collector and he sent his specimens of all but a few families to Dr. Hermann Loew of Meseritz, Germany, who used them as a basis for a series of monumental systematic papers. Loew's first article on this material also appeared in 1859, and it recorded from Washington 7 species of the dipterous family Helomyzidae, five of them new. In his series known as the "Centuries," Loew described 1,000 (!) species of North American flies. One hundred and fifty-seven of these species are recorded from the District of Columbia, of which 152 are new and 147 have the District as the sole and therefore type locality. Some 30 additional new species from Washington are described by this author in other papers.

Baron Osten Sacken himself described more than 80 species of diptera from the District of Columbia and 40 of gall flies or Cynipidae. Together Osten Sacken and Loew record more than 350 species of flies from the Washington region of which more than 260 were described by them as new to science.

Pefore the era of Osten Sacken was past, entomologists became a larger element in the scientific population of Washington, most of them being attracted here by the rise of Entomology in the United States Department of Agricul- 
ture. Among entomologists of this period, those paying most attention to the study of local insects were Henry Ulke, E. A. Schwarz, W. H. Ashmead, Theo. Pergande, and D. W. Coquillett. The latter described more than 40 new species of flies from the region; Mr. Ashmead described more than 240 species of Hymenoptera; while Mr. Ulke, with the assistance of Mr. Schwarz, issued the first list of beetles of the District including almost 3,000 species. The active workers of later years may be learned from the bibliographies below.

The region of the District of Columbia is a rich collecting ground for entomologists, as numbers of visiting specialists have testified. Not only is there a great variety of ecologic conditions, but unspoiled places are easily reached in almost any direction. The development of such an enormous field as the whole group of insects, even for a limited area necessarily is slow. What has been accomplished in the various groups is indicated by the citation of the principal results in the following bibliographies.

\section{BIBLIOGRAPHY.}

GENERAL.

Banks, Nathan.

At the Ceanothus in Virginia.

Ent. News XXIII, No. 3, March, 1912, pp. 102-110.

42 species of Hemiptera,

58 species of Coleoptera,

165 species of Hymenoptera, and

117 species of Diptera, recorded from Falls Church and vicinity.

Banks, Nathan.

NEUROPTERA.

A list of Neuropteroid insects, exclusive of Odonata, from the vicinity of Washington, D. C.

Proc. Ent. Soc. Wash., 6, No. 4, October, 1904, pp. 201-216, pl. II.

In all 174 species are recorded distributed as follows: Archiptera, 73; Neuroptera, 47; Trichoptera, 54.

Descriptions of New Nearctic Neuropteroid Insects.

Trans. Am. Ent. Soc., 32, pp. 1-20, pls. I-II, Nov., 1905.

5 new species from the vicinity of District of Columbia. 
A revision of the Nearctic Hemerobiidae.

Trans. Am. Ent. Soc., 32, pp. 21-51, pls. III-V, Dec., 1905.

9 species recorded from Washington region.

A revision of the nearctic Coniopterygidae.

Proc. Ent. Soc. Wash., 8, Nos. 3-4, Sept.-Dec., 1906, pp. 77-86, pls. VI-VII.

3 species from the vicinity of District of Columbia, 1 new.

New Trichoptera and Psocidae.

Journ. N. Y. Ent. Soc., 15, Nos. 3, Sept., 1907, pp. 162-166.

Four new species of Trichoptera and 2 of Psocidae from Washington region.

Occurrence of Dilar americana Leach.

Ent. News XVIII, No. 10, Dec., 19107, p. 450.

At Falls Church, Va., the type only known before.

THYSA NOPTERA.

Hood, J. D.

An annotated list of the Thysanoptera of Plummer's Island, Maryland.

Ins. Insc. Mens., 5, Nos. 4-6, April-June, 1917, pp. 53-65.

69 species from the vicinity of Washington.

ORTHOPTERA.

Allard, H. A.

The stridulations of some cone-headed grasshoppers (Conocephalus).

Proc. Ent. Soc. Wash., II, No. 3, 1910, pp. 121-124, pl. VI.

3 species.

The stridulations of some "katydids."

Proc. Biol. Soc. Wash., 23, pp. 35-40, 1910.

8 species.

Xiphidion stridulations.

Proc. Ent. Soc. Wash., 13, No. 2 (1910), 1911, pp. 84-87.

5 species.

The stridulations of some eastern and southern crickets (Orth.).

Ent. News, 22, No. 4, April, 1911, pp. 154-157.

3 species.

Locust stridulations (Orth.).

Ent. News, 25, No. 10, Dec., 1914, pp. 463-466.

3 species. 
Caudell, A. N.

The Cyrtophylli of the United States.

Journ. N. Y. Ent. Soc., 14, No. 1, March, 1906, pp. 32-45, pl. 1.

2 species.

The Decticinae (a group of Orthoptera) of North America.

Proc. U. S. Nat. Mus., 32, 1907, pp. 285-410.

2 species.

Three interesting Orthoptera from the vicinity of Washington, D. C.

Proc. Ent. Soc. Wash., 17, No. 4, Dec., 1915, p. 189.

Hebard, Morgan.

A revision of the species of the genus Nemobius (Orthoptera; Gryllidae) found in North America north of the Isthmus of Panama.

Proc. Ac. Nat. Sci. Philadelphia, pp. 394-492, figs. 1-31 (June, 1913), August 19, 1913.

8 species.

The American species of the genus Miogryllus (Orthoptera; Gryllidae).

Journ. N. Y. Ent. Soc., 23, No. 2, June, 1915, pp. 101-121.

Only 1 species.

The Blattidae of North America North of the Mexican Boundary. Mem. Am. Ent. Soc., 2, 284 and VI pp., 10 Pls., August 10, 1917.

13 species from vicinity of District of Columbia, one new.

Rehn, James A. G., and Hebard, Morgan.

A review of the North American species of the genus Ischnoptera (Orthoptera).

Proc. Ac. Nat. Sci. Philadelphia, pp. 407-453, figs. 1-30 (April, 1910 ), July 25, 1910.

7 species.

Studies in American Tettigoniidae (Orthoptera) I. A synopsis of the species of the genus Scudderia.

Trans. Am. Ent. Soc., 40, No. 4, Dec., 1914, pp. 271-314.

2 species.

Studies in American Tettigoniidae (Orthoptera) II. A synopsis of the species of the genus Amblycorypha found in America north of Mexico.

Trans. Am. Ent. Soc., 40, No. 4, Dec., 1914, pp. 315-340.

3 species and 1 subspecies. 
Srudies in American Tettigoniidae (Orthoptera) III. A synopsis of the species of the genus Neoconocephalus found in North America north of Mexico.

Trans. Am. Ent. Soc., 40, No. 4, Dec., 1914, pp. 365-413.

5 species.

Studies in American Tettigoniidae (Orthoptera) IV. A synopsis of the species of the genus Orchelimum.

Trans. Am. Ent. Soc., pp. 11-83, Pls. I-IV, April 9, 1915.

4 species.

Studies in American Tettigoniidae (Orthoptera) V. A synopsis of the species of the genus Conocephalus (Xiphidium of authors) found in North America north of Mexico.

Trans. Am. Ent. Soc., 41, No. 2, June, 1915, pp. 155-224, Pls. 15-20. 5 species.

The genus Gryllus (Orthoptera) as found in America.

Proc. Ac. Nat. Sci. Philadelphia, Vol. 67, Part 2, August, 1915, pp. 293-322, Pl. IV.

1 species.

Studies in American Tettigoniidae (Orthoptera) VII. A revision of the species of the genus Atlanticus (Decticinae).

Trans. Am. Ent. Soc., Vol. 42, No. 1, March, 1916, pp. 33-99, Pls. VI-VIII.

3 species.

Studies in the Dermaptera and Orthoptera of the Coastal Plain and Piedmont Region of the Southeastern United States.

Proc. Ac. Nat. Sci. Philadelphia, Vol. 68, Part II, pp. 87-314, Pls. 12-14, May, 1916.

70 species recorded from vicinity of Washington.

Fall, H. C.

COLEOPTERA,

Revision of the Ptinidae of Boreal America.

Trans. Am. Ent. Soc., 31, pp. 97-296, Pl. VII.

26 species from region of District of Columbia, several of them new.

Revision of the species of Diplotaxis of the United States.

Trans. Am. Ent. Soc., 35 pp. 1-97, Pl. 1, Jan.-March, 1909.

4 species from District of Columbia and vicinity, one new.

A revision of the North American species of Pachybrachys.

Trans. Am. Ent. Soc., 41, No. 3, Sept., 1915, pp. 291-486.

Records 14 species from vicinity of District of Columbia. 
Leng, Chas. W., and Shoemaker, Ernest.

A new genus and species of Lampyridae.

Journ. N. Y. Ent. Soc., 23, No. 1, March, 1915, pp. 55-56, Pl. 5.

Neoceletes crateracollis n. gen. et. sp. Glencarlyn, Va., June, 23, 1912.

Pierce, W. D.

Miscellaneous contributions to the knowledge of the weevils of the families Attelabidae and Brachyrhinidae.

Proc. U. S. Nat. Mus., 45, pp. 364-426, May 23, 1913.

Five species and 2 varieties listed from region of District of Columbia, one of the varieties new.

Schwarz, E. A.

Coleoptera on black locust (Robinia pseudacacia).

Proc. Ent. Soc. Wash. II, No. 1, April, 1891, pp. 73-76.

23 species.

Smith, John B.

Notes on the species of Lachnosterna of Temperate North America, with description of new species.

Proc. U. S. Nat. Mus. XI, 1888 (1889), pp. 481-525, Pls. 48-60.

Notes on collecting about Washington; 20 species obtained, 4 new (pp. 486-493).

Ulke, Henry.

A list of the beetles of the District of Columbia.

Proc. U. S. Nat. Mus. XXV, pp. 1-57, 1902.

2,975 species; many ecological notes.

HOMOPTERA.

Baker, A. C., and Turner, W. F.

Some intermediates in the Aphididae.

Proc. Ent. Soc. Wash., 18, No. 1, March, 1916 (April 5, 1916), pp. 10-14.

Records 6 species from vicinity of D. C.

Crawford, D. L.

A contribution toward a monograph of the homopterous insects of the family Delphacidae of North and South America.

Proc. U. S. Nat. Mus., pp. 557-640, Pls. 44-49, March 4, 1914.

Records 5 species from the District of Columbia.

A monograph of the jumping plant-lice or Psyllidae of the new wor'd.

Bul. 85, U. S. Nat. Mus., 186 pp., 30 Pls., 1914.

Lists 15 species from the vicinity of the District of Columbia. 
Gillette, C. P.

American Leafhoppers of the subfamily Typhocybinae.

Proc. U. S. Nat. Mus. 20, pp. 709-773, 149 figs., April 20, 1908.

Mentions 18 species and varieties from the District of Columbia region, 5 of which are described as new.

HE TEROPTERA.

Banks, Nathan.

Notes on our species of Emesidae.

Psyche, 16, April, 1909, pp. 43-48.

5 species from this region, one new.

Bueno, J. R. de la Torre.

The genus Notonecta in America north of Mexico.

Journ. N. Y. Ent. Soc., 13, No. 3, Sept., 1905, pp. 143-167, Pl. 7.

Records four species from District of Columbia and vicinity.

Heidemann, Otto.

Note on the food-plants of some Capsidae from the vicinity of Washington, D. C.

Proc. Ent. Soc. Wash. II, No. 2, June, 1892, pp. 224-226.

20 speces listed.

Heteroptera found on ox-eye daisy (Chrysanthemum leucanthemum).

Proc. Ent. Soc. Wash. IV, No. 3, May, 1899, p. 217.

27 species from vicinity of Washington.

Notes on North American Aradidae with descriptions of two new species.

Proc. Ent. Soc. Wash. VI, No. 3, 1904, pp. 161-165.

5 species from region of District of Columbia.

Notes on Heidemannia cixiiformis Uhler and other species of Isometopinae.

Proc. Ent. Soc. Wash. 9, April, 1908, pp. 126-130.

Two species from region of District of Columbia, one new.

Knight, H. H.

A revision of the genus Lygus as it occurs in America north of Mexico, with biological data on species from New York.

Bul. 391, Cornell Agr. Exp. Sta., May, 1917, pp. 555-645, P1. 23, figs. 158-208.

9 species from the vicinity, 4 new. 
McAtee, W. L.

Key to the Nearctic species of Paracalocoris (Heteroptera; Miridae).

Ann. Ent. Soc. Am. 9, No. 4, Dec., 1916, pp. 366-390.

Records from the vicinity of the District of Columbia, 5 species, 1 new and 12 varieties, 10 new.

Key to the Nearctic species of Leptoypha and Leptostyla (Heteroptera, Tingidae).

Bul. Brooklyn Ent. Soc. 12, No. 3, July, 1917, pp. 55-64.

5 species.

Reuter, O. M.

Bemerkungen ueber nearktische Capsiden, nebst Beschreibung neuer Arten.

Acta. Soc. Sci. Fennicae 36, No. 2, 1909, iii, 86 pp.

34 species and 6 varieties from District of Columbia region, 18 species and 2 varieties new; 3 new genera.

Busck, A.

LEPIDOPTERA.

A revision of the American moths of the family Gelechiidae, with descriptions of new species.

Proc. U. S. Nat. Mus. 25, pp. 767-938, Pls. 2S-32, May 9, 1903.

45 species from around Washington, 5 of them new.

A review of the Tortricid subfamily Phaloniinae with descriptions of new American species.

Journ. N. Y. Ent. Soc. 15, No. 1, pp. 19-36, March, 1907.

6 species from Washington district, all new.

Dietz, Wm. G.

Revision of the genera and species of the Tineid subfamilies Amydriinae and Tineinae inhabiting North America.

Trans. Am. Ent. Soc. 31, pp. 1-96, Pls. I-VI, Jan., 1905.

18 species from region of District of Columbia, 13 new.

Revision of the Blastobasidae of North America.

Trans. Am. Ent. Soc. 36, pp. 1-72, Pls. I-IV, Jan.-Mar., 1910.

11 species from region of District of Columbia, 8 new.

Dyar, H. G.

The North American Nymphulinae and Scopariinae.

Journ. N. Y. Ent. Soc. 14, No. 2, June, 1906, pp. 77-107.

6 species from region of District of Columbia, 1 new.

A review of the North American Chrysauginae.

Yroc. Ent. Soc. Wash. 10, pp. 92-96, Sept., 1908.

2 species from District of Columbia region. 
A review of the North American Pyralinae.

Proc. Ent. Soc. Wash. 10, pp. 96-102, Sept., 1908.

5 species from vicinity of District of Columbia, 1 new.

Kearfott, W. D.

New North American Tortricidae.

Trans. Am. Ent. Soc. 33, pp. 1-97, Jan.-Mar., 1907.

8 species from vicinity of District of Columbia, all new.

DIP'TERA.

Alexander, C. P.

New or little known crane-flies from the United States and Canada; Tipulidae, Ptychopteridae, Diptera, Part 3.

Proc. Ac. Nat. Sci. Phila. 68, Part 3, Oct., 1916, pp. 486-549, Pls. 25-31.

12 species in all from vicinity of District of Columbia, 1 new.

Back, E. A.

The robber-flies of America, north of Mexico, belonging to the subfamilies Leptogastrinae and Dasypogoninae.

Trans. Am. Ent. Soc. 35, pp. 137-400, Pls. II-XII, Apr.-Oct., 1909.

9 species.

Banks, Nathan.

[Conopid flies about Falls Church, Va.]

Proc. Ent. Soc. Wash., Vol. VIII, Nos. 3-4, Sept.-Dec., 1906, p. 108. 13 species.

The Psychodidae of the vicinity of Washington.

Proc. Ent. Soc. Wash., Vol. VIII, Nos. 3-4, Sept.-Dec., 1906, pp. 148-151.

12 species, 4 of which are originally described.

Eastern species of Rachicerus.

Proc. Ent. Soc. Wash. XV, No. 1, 1913, p. 51.

Key to 3 species all taken at nearby localities in Virginia.

Notes and descriptions of Pipunculidae.

Psyche 22, No. 5, Oct., 1915, pp. 166-170, Pl. 15.

Notes on 22 species, 4 new; states he has taken 27 species of Pipunculus in Virginia.

Notes on some Virginian species of Platypeza (Platypezidae, Dipt.).

Journ. N. Y. Ent. Soc., Vol. XXIII, No. 4, Dec., 1915, pp. 213-216, Pl. 17.

S species from Falls Church, Va., and vicinity, of which 5 are described as new. 
Synopses of Zodion and Myopa with notes on other Conopidae. Ann. Ent. Soc. Am. 9, No. 2, June, 1916, pp. 191-200.

List of 18 species taken at or near Falls Church, Va.

Banks, N., Greene, C. T., McAtee, W. L., and Shannon, R. C.

District of Columbia Diptera: Syrphidae.

Proc. Biol. Soc. Wash., Vol. 29, pp. 173-203, Sept. 22, 1916.

136 species of which 3 besides one variety are described as new.

Coquillett, D. W.

Revision of the Tachinidae of America North of Mexico, a family of parasitic two-winged insects.

Tech. Ser. Bul. No. 7, U. S. Div. Ent., 1897, 154 pp.

70 species, 11 new.

On the habits of the Oscinidae and Agromyzidae reared at the United States Department of Agriculture.

Bul. 10, N. S., U. S. Div. Ent., 1898, pp. 70-79.

9 species of Oscinidae and 8 of Agromyzidae.

New Diptera in the U. S. National Museum.

Proc. U. S. Nat. Mus. XXIII, pp. 593-618, Mar. 27, 1901.

13 new species of Ceratopogon.

New Diptera from North America.

Proc. U. S. Nat. Mus. XXV, pp. 83-126, Sept. 12, 1902.

8 new species, 7 of them Chiromidae and 4 of the genus Ceratopogon.

New genera and species of diptera.

Proc. Ent. Soc. Wash. 9, Apr., 1908, pp. 144-148.

4 new species from region of District of Columbia, 2 two of them representing new genera.

Cresson, E. T., Jr.

Studies in North American Dipterology; Pipunculidae.

Trans. Am. Ent. Soc. 36, pp. 267-329, Pls. V-IX, Dec., 1910-Jan., 1911. 14 species, 9 new.

Howard, L. O.

Notes on the mosquitoes of the United States; giving some account of their structure and biology with remarks on remedies.

Bul. No. 25 N. S., U. S. Div. Ent., 1900, 70 pp., 22 figs.

13 species.

Loew, H.

Diptera Americae septentrionalis indigena.

Berlin Ent. Zeitschr., 1861-1872. Published separately in Berlin, 2 vols., 1872 .

157 species, 152 new. 
Die Nordamerikanischen Arten der Gattungen Tetanocera und Sepedon.

Wiener Entomologische Monatschrift, Bd. III, Nr. 10, Oct., 1859, pp. 289-300.

7 species, 5 new.

Diptera americana ab Osten-Sackenio collecta.

Wiener Entomologische Monatschrift, Bd. IV, Nr. 3, Mar., 1860, pp. 79-84.

10 new species.

Die Nordamerikanischen Dolichopoden.

Neue Beiträge zur Kenntniss der Dipteren. Achter Beitrag, Berlin. $1861,100 \mathrm{pp}$.

11 new species.

Monographs of the Diptera of North America, Part I, On the North American Ephydrinidae.

Smithsonian Misc. Col., Apr., 1862, pp. 129-172.

6 species.

Monographs of the Diptera of North America, Part 11, On the North American Dolichopodidae.

Smiths. Misc. Col., Jan., 1864, 360 pp., Pls. 3-7.

23 species, 1 new.

Die Amerikanischen Ulidina.

Berliner Entomologische Zeitschrift, II, 1867, pp. 283-326.

3 species.

Monographs of the Diptera of North America, Part III, The North American Ortalidae.

Smiths. Misc. Col., Dec., 1873, pp. 71-209.

8 species, 3 new.

Monographs of the Diptera of North America, Part III, Review of the North American Trypetina.

Smiths. Misc. Col., Dec., 1873, pp. 211-330, Pls. 8-11.

4 species, 1 new.

Malloch, J. R.

The insects of the dipterous family Phoridae in the United States National Museum.

Proc. U. S. Nat. Mus. 43, pp. 411-529, Pls. 35-41, Dec. 14, 1912.

Records 1 species of Trupheoneura, 1 of Chaetoneurophora, 2 of Paruspiniphora, 2 of Dohrniphora, 1 of Hypocera, 1 of Conicera, 1 of Beckerina, 1 of Apocephalus, and 26 of Aphiochaeta. 


\section{Bulletin 1, Biological Society of Washington, 1918.}

A new genus and three new species of Phoridae from North America, etc.

Psyche. 20, No. 1, Feb., 1913, pp. 23-26, fig. 1.

All from this region.

A revision of the species in Agromyza Fallen, and Cerodontha Rondani (Diptera).

Ann. Ent. Soc. Am. VI, No. 3, Sept., 1913, pp. 269-336, Pls. 28-31.

13 species of Agromyza and 1 of Cerodontha.

A synopsis of the genera of Agromyzidae, with descriptions of new genera and species.

Proc. U. S. Nat. Mus. 46, pp. 127-154, Pls. 4-6, Dec، 6, 1913.

1 species of Milichiella, 1 of Pholeomyia, 2 of Phyllomyza, and 1 of Paramyia.

The genera of flies in the subfamily Botanobiinae with hind tibial spur.

Proc. U. S. Nat. Mus., 46, pp. 239-266, Pls. 23-24, Dec. 6, 1913.

4 species of Hippelates.

Some undescribed North American Sapromyzidae.

Proc. Biol. Soc. Wash. 27, pp. 29-42, Mar. 20, 1914.

6 species, all new.

American Black Flies or Buffalo Gnats.

Tech. Bul. No. 26, U. S. Bur. Ent., Apr. 6, 1914, 82 pp. 6 pls.

1 species of Prosimulium and 3 of Simulium.

The Chironomidae or midges of Illinois, with particular reference to the species occurring in the Illinois River.

Bul. III, State Lab. Nat: Hist. X, Art. VI, May, 1915, pp. 274-543, Pls. XVIII-XL.

Records 40 species from the District of Columbia region, $T$ of them new.

Mitchell, E. G.

Description of 9 new species of Gnats.

Journ. N. Y. Ent. Soc. 16, No. 1, Mar., 1908, pp. 7-14.

7 of the 9 new species of the genus Chironomus were collected neai Washington.

Osten Sacken, C. R. von.

New genera and species of North American Tipulidae with short palpi, with an attempt at a new classification of the tribe.

Proc. Ac. Nat. Sci Philadelphia 2, Aug., 1859, pp. 197-256, Pls. 3-4. 46 species, 42 of them new. 
Monographs of the Diptera of North America, Part I, On the North American Cecidomyidae.

Smiths. Misc. Col., Apr., 1862, pp. 173-205, Pl. 1.

33 species, 25 new.

Monographs of the Diptera of North America, Part IV, On the North American Tipulidae (part first).

Smiths. Misc. Col., Jan., 1869, pp. 1-320, Pls. 1-4.

(;4 species, 5 new.

A list of the Leptidae, Mydaidae and Dasypogonina of North America.

Bulletin of the Buffalo Society of Natural Sciences II, Apr., 1874, to March, 1875 (Oct., 1874), pp. 169-187.

1 Leptid and 6 Asilids.

Prodrome of a monograph of the Tabanidae of the United States.

Part I. The genera Pangonia, Chrysops, Silvius, Haematopota, Diabasis.

Mem. Bost. Soc. Nat. Hist. II, Part IV, No. 1, Apr., 1875, pp. 365-397.

Part II. The genus Tabanus.

Mem. Bost. Soc. Nat. Hist. II, Part IV, No. 4, Apr. 20, 1876, pp. 421-479.

Supplement.

Mem. Bost. Soc. Nat. Hist., Vol. II, Part IV, No. 6, March 2, 1878, pp. 555-560.

Records 10 species in all, 3 new.

Sturtevant, A. H.

Notes on North American Drosophilidae with descriptions of twenty-three new species.

Ann. Ent. Soc. Am. 9, No. 4, Dec., 1916, pp. 323-343.

6 new species.

Townsend, C. H. Tyler.

Notes on North American Tachinidae, sens. lat. with descriptions of new species.

Proc. Ent. Soc. Wash. II, pp. 134-146, April 2, 1891.

5 species, 4 new.

Notes on North American Tachinidae sens. str. with descriptions of new genera and species.

Trans. Am. Ent. Soc. 18, pp. 349-382, Nov., 1891.

1 new genus and species.

Contributions to the Dipterology of North America. I, Syrphidae. Trans. Am. Ent. Soc. 22, pp. 33-55, Mar., 1895.

18 species, 1 new. 
Contributions to the Dipterology of North America II, Tabanidae, Conopidae, Tachinidae, etc.

Trans. Am. Ent. Soc. 22, pp. 55-80, Mar., 1895.

8 species, 1 new.

Notes on some interesting flies from the vicinity of Washington.

Proc. Ent. Soc. Wash., Vol. I, Nov. 4,-Dec., 1888-Dec., 1889 (1890), pp. 254-255.

6 species, 1 undetermined.

Ashmead, Wm. H.

HYMENOPTERA.

Descriptions of new Braconidae in the collection of the U. S. National Museum.

Proc. U. S. Nat. Mus., 1888, pp. 611-671, Sept. 25, 1889.

19 species, 18 new.

Descriptions of new Ichneumonidae in the collection of the U. S. National Museum.

Proc. U. S. Nat. Mus. XII, pp. 387-451, Apr. 21, 1890.

13 species, all new.

A monograph of the North American Proctotrypidae.

Bul. 45, U. S. Nat. Mus., 1893, 472 pp., 18 pls.

194 species, 177 new.

Descriptions of new parasitic hymenoptera.

Trans. Am. Ent. Soc. 23, pp. 179-234, June, 1896.

33 species, 31 new.

Banks, Nathan.

Sleeping habits of certain hymenoptera.

Journ. N. Y. Ent. Soc. 10, No. 4, Dec., 1902, pp. 209-214.

Notes on 6 species at Falls Church, Va.

Psammocharidae: Classification and Descriptions.

Journ. N. Y. Ent. Soc. 19, No. 4, Dec., 1911, pp. 219-237.

Includes 5 new species from region of District of Columbia.

New species of Psammocharidae.

Journ. N. Y. Ent. Soc. 22, No. 4, Dec., 1914, pp. 300-306.

4 new species from District of Columbia region.

Bradley, J. C.

The Evaniidae, ensign-files, an archaic family of hymenoptera.

Trans. Am. Ent. Soc. 34, pp. 101-194, Pls. V-XV, Apr.-June, 1908.

Notes on Evaniidae (Hym.).

Zeitschr. f. Hym. Dipt., 1905, pp. 26-27.

Together these record 3 species, 2 new, from District of Columbia. 
Contributions toward a monograph of the Mutillidae and their allies of America north of Mexico.

I. A Revision of Ephuta Say.

Trans. Am. Ent. Soc. 42, No. 2, June, 1916, pp. 187-198.

II. A Revision of Timulla Ashmead, etc., pp. 199-214.

III. The Mutillidae of the Eastern United States, pp. 309-336.

20 species, 4 new.

Coskerell, T. D. A.

Notes on some bees from Virginia.

Proc. Ent. Soc. Wash. XVII, No. 1, Mar., 1915, pp. 3-5.

3 species visiting sunflower and lima bean flowers at Falls Church, Va.

Crawford, J. C.

A new family of parasitic hymenoptera.

Proc. Ent. Soc. Wash. 11, No. 2, Aug., 1909, pp. 63-64, Pl. 5.

Vanhorniidae, based on Vanhornia eucnemidarum, n. gen. et. sp.

Descriptions of new hymenoptera, 1.

Proc. U. S. Nat. Mus. 39, pp. 617-623, Feb. 25, 1911.

Winnemana argei, n. gen. et. sp. Plummers Id., Md.

Cushman, R. A.

A revision of Hymenopterous insects of the tribe Cremastini of America north of Mexico.

Proc. U. S. Nat. Mus. 53, pp. 503-551, Aug. 22, 1917.

9 species from this vicinity, 7 new.

Gahan, A. B.

Aphidiinae of North America.

Bul. 152, Maryland Agr. Exp. Sta., Apr., 1911, pp. 147-200, figs. 1-11. 13 species.

Descriptions of 2 new genera and 6 new species of parasitic hymenoptera.

Proc. Ent. Soc. Wash. 14, No. 1, Jan.-Mar., 1912, pp. 2-8.

4 new species, representing also 2 new genera.

A revision of the North American Ichneumon-flies of the subfamily Opiinae.

Proc. .U S. Nat. Mus., Vol. 49, pp. 63-95, Pls. 34-35, Aug. 23, 1915.

5 species from District of Columbia region.

Girault, A. A.

A systematic monograph of the Chalcidoid Hymenoptera of the sub-family Signiphorinae.

Proc. U. S. Nat. Mus. 45, pp. 189-233, May 22, 1913.

4 species from District of Columbia. 
New miscellaneous Chalcidoid Hymenoptera with notes on de scribed species.

Ann. Ent. Soc. Am. 9, No. 3, Sept., 1916, pp. 291-308.

5 new species.

Descriptions of miscellaneous North American Chalcidoid Hymenoptera of the family Eulophidae.

Proc. U. S. Nat. Mus. 51, pp. 39-52, Oct. 16, 1916.

9 species, 8 new.

New species of parasitic hymenoptera.

Bul. Brooklyn Ent. Soc. 11, No. 5, Dec., 1916, pp. 111-113.

7 new species.

Descriptions of miscellaneous chalcid-fies.

Ins. Insc. Mens. 4, Nos. 10-12, Jan. 12, 1917, pp. 109-121.

10 new species from the region of District of Columbia.

Isely, Dwight.

A synopsis of the petiolate wasps of the family Eumenidae (Hymenoptera) found in America north of Mexico.

Ann. Ent. Soc. Am. 10, No. 4, Dec., 1917, pp. 345-366.

2 species of Eumenes and two of Zethus.

Lovell, John $\mathrm{H}$.

The bees of Virginia-Prosopis, Sphecodes, Osmia.

Ent. News XX, No. 10, Dec., 1909, pp. 412-417.

6 species of Prosopis, 1 new, 7 species of Sphecodes, and 6 species of Osmia recorded from Falls Church, Great Falls and other localities in the vicinity of the District.

Osten Sacken, C. R.

On the Cynipidae of the North American Oaks and their galls.

Proc. Ent. Soc. Phila. I, pp. 47-72, Oct., 1861.

Describes 27 kinds of galls, with 25 scientific names of flies and inquilines, 18 of them new.

Ueber die Gallen und andere durch Insecten Hervorgebrachte Pflanzendeformationen in Nord-America.

Entomologische Zeitung (Stettin) 22, No. 10-12, Oct.-Dec., 1861, pp. 405-423.

Records, apparently, almost exclusively from the vicinity of Washington, the following galls: Cynipidae, 35, 3 described as new; Cecidomyiidae, 34, 2 new; Hemiptera, 10, 2 new; Acarina, 3.

Additions and corrections to the paper entitled: "On the Cynipidae of the North American Oaks and their Galls."

Proc. Ent. Soc. Phila. I, No. 8, Sept., 1862, pp. 241-259.

Notes on 15 galls additional to previous paper with 8 scientific names, 4 new. 
Contributions to the natural history of the Cynipidae of the United States and of their galls.

Proc. Ent. Soc. Phila., Vol. II, pp. 33-49, April. 1863.

4 new species.

Contributions to the Natural History of the Cynipidae of the United States and their Galls.

Trans. Am. Ent. Soc. III, pp. 54-64, Mar., 1870.

3 new species.

Rohwer, S. A.

New sawflies in the collections of the United States National Museum.

Proc. U. S. Nat. Mus. 41, pp. 377-411, Oct. 14, 1911.

Records 8 species from this region, 2 of them being represented by new varieties and 1 by a new subspecies.

Notes on sawflies with descriptions of new species.

Proc. U. S. Nat. Mus. 43, pp. 205-251, Sept. 30, 1912.

10 species from this region, 9 new.

A synopsis and descriptions of the Nearctic species of sawflies of the genus Xyela, with descriptions of other new species of sawflies.

Proc. U. S. Nat. Mus. 45, pp. 265-281, May 22, 1913.

6 species from District of Columbia region, all new.

Descriptions of 2 new genera of parasitic hymenoptera.

Psyche 21, No. 2, April, 1914, pp. 79-81.

2 new genera and species.

Descriptions of new species of Hymenoptera.

Proc. U. S. Nat. Mus., Vol. 49, pp. 205-249, July 16, 1915.

11 species of sawflies, 10 new, and 5 other new species from region of District of Columbia.

Descriptions of 31 new species of Hymenoptera.

Proc. U. S. Nat. Mus. 53, pp. 151-176, June 5, 1917.

5 new species from the District of Columbia region.

Viereck, H. L.

Descriptions of 6 new genera and 31 new species of Ichneumonflies.

Proc. U. S. Nat. Mus. 40, pp. 173-196, Apr. 17, 1911.

4 new species.

Descriptions of 1 new family, 8 new genera, and 33 new species of Ichneumon flies.

Proc. U. S. Nat. Mus. 43, pp. 575-593, Dec. 31, 1912.

Myersiidae new family based on Myersia laminata, n. gen. et. sp. and 2 other new species, 1 representing a new genus. 
Descriptions of 10 new genera and 23 new species of Ichneumonflies.

Proc. U. S. Nat. Mus. 44, pp. 555-568, Apr. 18, 1913.

6 new species representing also 1 new genus and 1 new subgenus.

One new genus and 5 new species of Ichneumon-flies.

Proc. Biol. Soc. Wash. 29, pp. 165-171, Sept. 6, 1916.

All from vicinity of Washington.

\section{OTHER INVERTEBRATES.}

The work upon invertebrates, other than insects, of the District of Columbia, that has been embodied in local lists, has been upon 4 groups: the rotifers, the molluses, the spiders, and the daddy-long-legs or Phalangids. The list of shells was published in 1855 and includes 90 species; the spider list of 1893 enumerated 308 species; that relating to the daddy-long-legs in 1904, 10 species; and the catalog of rotifers or wheel-animalcules of 1913,246 species.

Girard, Chas.

\section{BIBLIOGRAPHY.}

Catalogue of recent shells and other molluscs found in the Districe of Columbia, prepared from specimens in the cabinet of Dr. E. Foreman.

Proc. Nat. Institute, N. S., Vol. I, No. 2 (1855-6), pp. 78-82.

Read April 16, 1855; presented for publication June 11, 1855.

90 species enumerated.

Marx, Geo.

A list of the Araneae of the District of Columbia.

Proc. Ent. Soc. Wash., Vol. II (1891), 1893, pp. 149-162.

308 species recorded. It is noted that 62 undescribed species also had been collected.

Banks, Nathan.

Phalangids in the District of Columbia.

Journ. N. Y. Ent. Soc. XII, No. 4, Dec., 1904, p. 256.

10 species listed.

Harring, Harry $\mathrm{K}$.

A list of the rotatoria of Washington and vicinity, with descriptions of a new genus and 10 new species.

Proc. U. S. National Museum, Vol. 46, pp. 387-405, Pls. 34-38, Dec. 31, 1913.

246 species in all. 
A revision of the rotatorian genera Lepadella and Lophocharis with descriptions of 5 new species.

Proc. U. S. Nat. Mus. 51, pp. 527-568, Dec. 21, 1916.

6 species from District of Columbia region, 1 new.

\section{FISHES.}

Although uninteresting to many students of natural history, fishes, in the region of the District of Columbia have received more attention than any group of vertebrates except birds. Three principal lists have been published and the number of species recorded now stands at 94 . At least 14 of these species are known to have been introduced into the Potomac as food fishes; this number includes the spotted and forked-tail catfishes, carp, goldfish, tench, ide, two speries of crappie, at least one sunfish, the goggle-eye, warmouth, the large-mouth and small-mouth black bass and the wall-eyed pike.

The fact that tide-water ends in our vicinity makes the distribution of fishes particularly interesting. The number of true salt-water fishes that stray far enough upstream to be included in the District fauna is now placed at 14 . Among these fishes are a shark, the menhaden, an anchovy, a Cyprinodon, the silvergar, the pipefish, pigfish, spot, whiting, angel-fish, a goby, toadfish, sea-robin and sole.

Of the anadromous fishes or those which run up from salt water to fresh to spawn, we have 5 ascending as far as Little Falls, namely, two species of sturgeons, and 3 of herrings, and 3 that keep on Great Falls, these being the shad, striped bass and white perch. It is recorded ${ }^{23}$ also that an Atlantic salmon was caught in the Potomac about June 10, 1885. In addition to these there is the lamprey which runs into all sorts of small streams to spawn, and the eel which spawns in salt water and after ascending the river reaches almost all bodies of water, even those apparently isolated. These fishes are of coastal affinities, but we have one species definitely characteristic of the higher western country, that being the brook trout, which has been found in Difficult Run, Va.

\footnotetext{
${ }_{23}$ Wooldridge, J., Natural Advantages of the City of Washington, D. C., 1892 , p. 38.
} 
The fishes thus far captured in this region belong to 32 families of which that most humerously represented by species is the minnow family with 24 . There are 12 species of sunfishes and basses, 8 of perches and darters, 7 of catfishes and 5 each of the sucker, and shad families. Twenty families are represented by only one species each. Of the species of fishes that have been described from this region at least 3 are now recognized as good species and one as a variety; these are two minnows, Notropis hudsonius amarus Girard, Notropis analostanus Girard, a silver-side, Menidia beryllina Cope, and a darter Boleosoma effulgens Girard.

\section{BIBLIOGRAPHY.}

Smith, Hugh M., and Bean, Barton A.

List of Fishes known to inhabit the waters of the District of Columbia and vicinity.

Bul. U. S. Fish Commission, 1898 (1899), pp. 179-187.

Lists 81 species.

Bean, Barton A., and Weed, Alfred C.

Recent additions to the fish fauna of the District of Columbia.

Proc. Biol. Soc. Wash. XXIV, pp. 171-174, June 16, 1911.

Lists 12 species, 11 of them additional to previous list.

McAtee, W. L., and Weed, Alfred C.

First list of the fishes of the vicinity of Plummers Island, Md.

Proc. Biol. Soc. Wash. XXVIII, pp. 1-14, Feb. 12, 1915.

Lists 54 species, 1 new to District list.

Radcliffe, Lewis, and Welsh, W. W.

A list of the fishes of the Seneca Creek, Montgomery County, Maryland, region.

Proc. Biol. Soc. Wash. 29, pp. 39-45, Feb. 24, 1916.

Annotated list of 41 species, none additional to District list.

\section{BATRACHIANS AND REPTILES.}

Though these two groups are not closely related, customarily they are treated together, a procedure followed in the list by Dr. W. P. Hay the only report on these forms for the region of the District of Columbia. The batrachians inhabiting this vicinity comprise 14 species of salamanders, 3 toads, and 10 frogs, and the reptiles include 4 lizards, 21 snakes and 11 turtles. This tabulation includes two more batrachians than are listed by Dr. Hay, namely: Fowler's 
toad, a species more perfectly understood now than then, and the spotted salamander. Three turtles also have been added, one of which, the northern wood tortoise (Clemmys insculpta), has been collected several times near Plummers Island, Md. The name of one snake is removed, the form being Natrix bisecta of Cope, which as Dr. Hay states was founded on an abnormal and unique specimen. This type specimen was collected in Washington, and the material upon which a species of tree frog, Hyla evittata, was described by Gerrit S. Miller was obtained nearby at Four-mile Run, Va.

Only two of the species of snakes reported are venomous, namely: the copperhead and the rattlesnake. The former is common, but the latter apparently is extinct. Warden recorded ${ }^{24}$ it in 1816. The species here verging on their northern limit are the mud eel (Siren lacertina), Holbrook's salamander (Spelerpes guttolineatus), the brown-back lizard (liygosoma laterale), the six-lined lizard (Cnemidophorus sexlineatus), the spotted racer (Callopettis guttatus), scarlet snake (Cemophora coccinea), and the keeled green snake (Cyclophis aestivus). Species venturing little beyond the Piedmont Plateau are the long-tailed triton (Spelerpes longicaudus), brown triton (Desmognathus fusca), and the Allegheny blacksnake (Callopeltis obsoletus), while the diamond back terrapin (Malaclemmys centrata) and the two turtles mentioned in the last item of the following bibliography belong to the coastal plain fauna. Whether the northern wood-tortoise (Clemmys insculpta) and the Jefferson Salamander (Ambystoma jeffersonianum fuscum) should also be considered as highland species or whether they exist here merely on the southern fringe of a more general range is uncertain.

\section{BIBLIOGRAPHY.}

Fisher, A. K.

Syelerpes guttolineatus Holbrook, in the vicinity of Washington, D. C.

Am. Nat. 21, No. 7, July, 1887, p. 672.

This and 4 other species captured near Munson Hill, Va.

24 Warden, D. B.-A chorographical and statistical description of the District of Columbia, 1816, p. 13. 
Miller, Gerrit S., Jr.

A new tree frog from the District of Columbia.

Proc. Biol. Soc. Wash. 13, pp. 75-78, Sept. 28, 1899.

Hyla evittata, n. sp., Four-mile Run, Va.

Hay, W. P.

A list of the batrachians and reptiles of the District of Columbia and vicinity.

Proc. Biol. Soc. Wash. XV, pp. 121-145, figs. 1-3, June 20, 1902.

Lists 56 species of which 1 is invalid and 3 are without definite records.

Stejneger, Leonhard.

A salamander new to the District of Columbia.

Proc. Biol. Soc. Wash. 15, pp. 239-240, Dec. 16, 1902.

Ambystona maculatum (punctatum), a species now known to be fairly common and widely distributed.

A snake new to the District of Columbia.

Proc. Biol. Soc. Wash. 18, pp. 73-74, Feb. 21, 1905.

Cemophora coccinca, Anacostia.

Henshaw, H. W.

An extension of the range of the wood tortoise.

Proc. Biol. Soc. Wash. XX, p. 65, June 12, 1907.

raken Aug. 18, 1906, near Plummers Island, Md.

Allard, H. A.

Fowler's Toad (Bufo fowleri Putnam).

Science N. S. XXVI, Sept. 20, 1907, pp. 383-384.

Records this species from Washington, D. C.

Dunn, E. R.

A preliminary list of the reptiles and amphibians of Virginia.

Copeia, No. 53, Jan. 25, 1918, pp. 16-27.

Records 21 species of reptiles and 16 amphibians from Alexandria County, and 25 and 22 , respectively, from Fairfax. Two species of turtles, Pseudemys concinna and Graptemys pseudogeographica are additional to those recorded in previous publications.

\section{BIRDS.}

Some of the earlier references to the birds of the region are of interest. We are informed ${ }^{25}$ that one of the Indian names for the Potomac was Cohonguroton or river of swans.

${ }^{2}$ Keim, DeB. Randolph. Keim's Illustrated Handbook. Washington and its Environs, 1874, p. 39. 
It is said, ${ }^{26}$ however, that Occoquan was the farthest up river feeding place of the swans; but flocks of as many as 300 were seen there and of two kinds, both trumpeter and whooper. There is no later record of the trumpeter swan, however, and the whooper in modern books is called whistling swan to distinguish it from the European bird.

The Potomac was a noted resort for the canvasback duck, the farorite ground for the species extending from Analostan Island to Craney Island 25 miles below. It is said that myriads of them were present, fairly covering the stream. ${ }^{27}$ As if in prophecy one author (Elliot) deprecates the shooting with large guns, especially at night. As we now know, it is due to this and similar practices that such large gatherings of these splendid birds are things of the past.

Evidently it was not necessary in those early days for hunters to journey far from the city. In 1797, Francis Baily remarks : 28

"Game is plenty in these parts, and, what perhaps may appear to you remarkable, I saw some boys who were out a shooting, actually kill several brace of partridges in what will be one of the most public streets of the city." "In 1836 a flock of 30 to 40 wild turkeys flew over Georgetown going toward Chain Bridge and a man on the bridge killed 9 of them." 29

In the Proceedings of the National Institute for the Promotion of science are various interesting notes relating to the birds of the District. The donations announced at the meeting of September 12, 1842, especially are noteworthy, ${ }^{30}$ Four specimens of Leach's petrel, one of Wilson's petrel, and one Audubon shearwater were presented. The birds were taken the preceding month, August, 1842, and the records in each case are the first for the District. This

${ }^{29}$ Eliot, Jonathan. Historical Sketches of the Ten Miles Square forming the District of Columbia, etc., 1830, p. 431.

$2 \pi$ Hall, Basil. Travels in North America in the Years 1827 and 1828. Edinburgh, 1829, Vol. III, p. 68.

${ }_{28}$ Journal of a tour in Unsettled Parts of North America in 1796 and 1797, London 1856 , p. 128.

Nile's Weekly Register, 51, 128, October 22, 1836.

20 Third Bulletin of the Proceedings of the National Institute for the Promotion of Science. Feb., 1842, to Feb., 1845, p. 251. 
incursion of maritime species is undoubtedly that referred to by Haley, who says "during a violent easterly storm a few years ago, the Potomac was covered with multitudes of Mother Cary's chickens (Thalassidroma leachii) which had been forced out of their usual course by the gale. ${ }^{31}$

In the bulletin of the National Institute also are earlier records (all in 1842 and 1843) for the surf scoter (Second Bul., p. 148), the double-crested cormorant, old squaw (Third Bul., p. 262), snow bunting (Third Bul., p. 224), and yeliow rail (Third Bul., p. 320) than are cited in later publications, and the only record for the ivory gull (Second Bul., p. 134).

Of birds which once frequented the District but which now are gone we may mention: the passenger pigeon, now wholly extinct, the sandhill crane, Carolina parakeet, and prairie chicken. ${ }^{32}$ The wild turkey and the ruffed grouse no longer find congenial haunts within the District, but occur sparingly in some of the wildest adjoining territory. Practically the same is true of the pileated woodpecker, although this species being of a more roving disposition may, occasionally, be detected within our limits. The wood duck, once a breeder within the District, now nests only in the more secluded parts of nearby stream valleys, but still occurs within the District during migration. These species have been driven away, either by direct persecution by man, or by the destruction of habitats essential to their welfare. Another bird, the black-throated bunting or dick-cissel, has departed for reasons of its own. Much territory here is suited to its needs, but the bird has withdrawn from much of its former eastern range, including the District of Columbia. On the other hand, certain species have become more common in recent years. Among them we may mention the crow blackbird, orchard oriole, Cape-May warbler, butcherbird, robin, and the mockingbird. To replace the lost blackthroated bunting another finch, Bachman's sparrow, is gradually occupying this region as a breeding home. The

31 Washington Described, 1861, p. 27.

${ }^{32}$ In the National Museum is a specimen of prairie chicken that was taken in the Custis Spring marsh March 13, 1885. This isolated occurrence is rather mysterious. 
starling, a new-comer, sometimes abundant in winter, has also begun to nest in small numbers.

The English sparrow was introduced into Washington in 1871. The following contemporaneous account of the matter may not be entirely pleasing to those who have had disagreeable experience with this hardy little stranger. "A flock of imported sparrows was set at liberty in the public grounds in 1871, for the destruction of insects. Each year new cages are placed in the trees for the accommodation of their increased numbers. These useful birds are fed regularly every morning during the winter in Franklin, Lafayette and other squares." 33

The first list of birds of the District of Columbia, that has so far come to light was published by David Baillie Warden in 1816. (See bibliography below.) It contained 32 species, among them the passenger pigeon, now extinct, and the snowy owl, a rare bird here.

The beginning of the modern series of lists is that of Coues and Prentiss of 1861. It contains 225 species. Jouy increased this to 230 in 1875 , and to 240 in 1877 . The second edition of Coues and Prentiss's work in 1883 contained 248 species. No other list appeared during the next 15 years, in which period a number of additions to the District avifauna were noted, the total number of species reaching 284 (See bibliography) as recorded by Richmond in 1898. This number is increased by one in Cooke's list of 1908, which omits one living species listed by Richmond, the true total, therefore, being 286. The introduced starling (Sturnus vulgaris), which has been seen in numbers in and about the District since 1913 (a number breeding in 1917), is a species not included in any of the published lists. The European skylark and white-rumped sandpiper also have been recently observed. As noted in previous pages, the ivory gull, trumpeter swan, and white ibis are additional species which have been recorded as visitants to this region but for which there are no definite records.

Keim's Illustrated Handbook. Washington, etc., 1874, p. 39. 


\section{BIBLIOGRAPHY.}

Warden, David Baillie.

[Birds seen in the District of Columbia.]

A chorographical and statistical description of the District of Columbia, Paris, 1816, pp. 210-211.

32 species.

Coues, Elliott, and Prentiss, D. Webster.

List of birds ascertained to inhabit the District of Columbia, with the times of arrival and departure of such as are non-residents, and brief notices of habits, etc.

Sixteenth Ann. Rep. Smiths. Inst., 1861 (1862), pp. 399-421.

226 species listed, 1 erroneously.

Burroughs, John.

Spring in Washington, with an eye to the birds.

Atlantic Monthly, Vol. XXIII, May, 1869, pp. 580-591.

Reprinted in Wake Robin, Cambridge, 1895, pp. 127-156.

Notes on flowers; birds; crow roosts; orchard oriole breeding in Capitol grounds; other birds there; black-throated bunting; redheaded the most common woodpecker, more common than the robin; and summer yellow-bird more common in town than out.

Shufeldt, R. W.

Birds of the District of Columbia.

Field and Forest, Vol. I, Nos. 8-9, Jan.-Feb., 1876, pp. 79-80.

A list of 38 common permanent residents and 29 common winter residents, the latter including Ectopistes migratorius. Six other species are mentioned.

Jouy, Pierre Louis.

Catalogue of the Birds of the District of Columbia.

Field and Forest, Vol. II, No. 9, Mar., 1877, pp. 154-156; No. 10, Apr., 1877, pp. 178-181.

240 species in all. Mr. Jouy read a list of 230 species of birds at a meeting of Potomac-side Naturalists Club, Nov. 15, 1875.

Coues, E. and Prentiss, D. Webster.

Remarks on Birds of the District of Columbia.

Field and Forest, Vol. II, No. 11, May, 1877, pp. 191-193.

Comment on Jouy's Catalogue, with which these remarks were also separately published, Washington, D. C., 1877, pp. 1-11.

Jouy, Pierre Louis.

Field Notes on some of the Birds of the District of Columbia.

Field and Forest, Vol. III, No. 3, Sept., 1877, pp. 51-52.

Notes on 6 species, one, the lark sparrow, an addition to the list. 
Roberts, W. F.

Additions to the List of District Birds.

Field and Forest, Vol. III, Nos. 10-12, Apr.-June, 1878, p. 172.

Macrorhamphus griseus. Total now, 242.

Coues, Elliott, and Prentiss, D. Webster.

Avifauna Columbiana; being a list of birds ascertained to inhabit the District of Columbia, with the times of arrival and departure of such as are non-residents, and brief notices of habits, etc.

The second edition revised to date and entirely rewritten.

Bul. No. 26, U. S. Nat. Mus., 1883, 133 pp., 4 maps, 100 figs.

Lists 248 species; describes various parts of the Washington region.

Henshaw, H. W.

Ornithology of the Zoological Park.

Ann. Rep. Smith. Inst. (1890), 1891, pp. 66-68.

61 breeding species listed. A few migrants mentioned.

Richmond, C. W.

List of birds of the District of Columbia, Washington, D. C. July, 1896. Part I, pp. 1-12 (All issued).

A regrettably uncompleted list, broken off at the fortieth species.

Maynard, L. W.

Birds of Washington and vicinity, including adjacent parts of Maryland and Virginia.

With introduction by Florence A. Merriam (In revised edition Florence Merriam Bailey), pp. 11-18, and a list of all birds found in the District of Columbia by Dr. C. W. Richmond, pp. 178-186.

Washington, D. C., 1898, 204 pp., 18 figs., revised edition 1902, 210 pp., 18 figs.

Includes 292 forms; 1 hybrid, 5 subspecies of species otherwise represented and 2 extinct birds are listed, the true total being 284 living species.

Bartsch, Paul.

Notes on the herons of the District of Columbia.

Smiths. Misc. Coll. 451, pp. 104-111, Pls. 32-38, Dec. 9, 1903.

Habits and other notes for 9 species.

Osgood, W. H.

"Helminthophila lawrencei" near the District of Columbia.

Auk XXIV, No. 3, July, 1907, pp. 342-343.

Taken on Plummers Island, Md., May 12, 1907. This bird is a hybrid between $H$. chrysoptera and $H$. pinus, and therefore not an additional species to the District list. 
Cooke, W. W.

Bird Migration in the District of Columbia.

First Ed. Proc. Biol. Soc. Wash., Vol. XXI, pp. 107-118, April 11, 1908.

Second Ed. Proc. Biol. Soc. Wash., Vol. XXVI, pp. 21-26, Feb. 7, 1913.

These two publications give detailed information on the migration season of birds in the District and surrounding region, and bring the records of species observed up to date.

The total number of forms listed is 294 of which 1 is extinct, 2 are hybrids and 6 are subspecies of species otherwise represented, leaving 285 living species known to occur in the vicinity of the District. One extinct bird, the Carolina Paroquet, and 1 living species, the American wigeon, listed by Richmond, were inadvertently omitted.

\section{MAMMALS.}

The mammals that maintain existence in thickly populated areas are small, inconspicuous and elusive. The larger forms that are compelled to live more or less in the open disappear. Among those which have inhabited the vicinity of the District of Columbia within historic times, but which are now locally extirpated, are buffalo, elk, white-tailed deer, wild-cat, puma, gray wolf, black bear, pine marten, beaver and black rat. The last-named species was introduced from the Old World, but disappeared before its later imported congener and rival, the brows rat. Buffalo disappeared from Virginia and therefore from this vicinity soon after the establishment of the first permanent settlements, but gray wolves were present and destructive as late as $\mathbf{1 7 2 8 .}$ This is proved by the fact that in that year a law was passed placing a bounty of 200 pounds of tobacco upon each wolf scalp. Elk persisted in Virginia until 1844.

Forty-one species of mammals are now known to live in the neighborhood of the city of Washington, of which three were described as new to science as late as 1910 to 1913 . Two of these species are shrews, one of which is called Microsorex winnemana, and the third species is a bat named Myotis winnemana. The specific name winnemana means 
"beautiful island" and alludes to Plummers Island, the Home of the Washington Biologists' Field Club, near and upon which the types of the two species respectively were collected. Included in the total number for the region are the opossum, 5 species of squirrels, the woodchuck, 9 species of mice and rats, the musk-rat, rabbit, house-cat, 2 foxes, the raccoon, skunk, otter, mink, weasel, 5 shrews, 2 moles, and 8 species of bats. One other species, the golden mouse (Peromyscus nuttallii) of more southern distribution has been reported, ${ }^{34}$ but the record needs verification. The rice rat (Oryzomys palustris) has been taken at Colonial Beach, Virginia, and sooner or later probably will be captured within the accepted limits of the District fauna.

The red squirrel is about at its eastward limit in this region, ranging but little farther out upon the coastal plain, while the rood rat is restricted to the Piedmont Plateau. Cooper's lemming mouse and Sorex fontinalis seem to be confined to sphagnum bogs; the distribution of former is more to the northward and in the mountains. The District is at the northern limit of the range of the harvest mouse.

\section{BIBLIOGRAPHY.}

Bailey, Vernon.

List of the mamnals of the District of Columbia.

Proc. Biol. Soc. Wash., Vol. X, pp. 93-101, May 28, 1896.

The list names 37 species (including Felis domestica) known to occur within 20 miles of the Capitol and most of them within the District limits: The record for the wildcat is conjectural and probably should have been added to the list of locally extirpated species which consists of 7 , the white-tailed deer and pine marten being omitted.

Mearns, L. Z.

On the occurrence of the genus Reithrodontomys in Virginia.

Am. Nat. 31,1897, pp. 160-161.

Records R. lecontii from Ft. Myer, Va. This form is now called R. humulis impiger. (See Howell, A. H., N. A., Fauna, 36, 1914, pp. 20-21.)

\footnotetext{
Haley, W. D. In Philip's Washington Described, 1861, P. 23.
} 
Preble, Edward A.

A new Microsorex from the vicinity of Washington, D. C.

Proc. Biol. Soc. Wash. XXIII, pp. 101-102, June 24, 1910.

Microsorex winnemana sp. n. Type from bank of Potomac River near Stubblefield Falls, Va., April 25, 1903.

Hollister, N.

Remarks on the long-tailed shrews of the eastern United States with description of a new species.

Proc. U. S. Nat. Mus. 40, pp. 377-381, April 17, 1911.

Describes Sorex fontinalis n. sp. from Beltsville, Md. This species was recorded as S. personatus, by Bailey. A District record for the long-nosed shrew ( $S$. longirostris) aiso is given.

Nelson, E. W.

A new bat from the eastern United States.

Proc. Biol. Soc. Wash. XXVI, pp. 183-184, Aug. 8, 1913.

Myotis winnemana sp. n. Type from Plummer's Island, Md., Aug 31, 1907. A. K. Fisher.

\section{EARLY HISTORY OF MAN IN THE DISTRICT.}

In certain localities about the District, relics of the aborigines are abundant and they throw much light on the mode of life of those tribes of the North American Indians that inhabited the neighborhood. These were of Algonquian stock, the tribes living in this region in Captain John Smith's time being the Nacochtanks, Taukenets, and Moyaones with headquarters respectively along Eastern Branch, near Mount Vernon, and near the mouth of the Piscataway River. The settlements of these tribes were broken up about 1676 by raids of the Susquesahanocs, and some of them retired to Virginia, where they joined the Pamunkeys, while those remaining in Maryland consolidated under the name of Piscataways. These removed to Pennsylvania about 1700, leaving this region in undisputed control of the white men.

The Indians of this region spent their time in fishing, trapping, hunting, and fighting. The relics of their occupation of the land comprise every variety of stone implement common to the North American Indian, fish hooks, pottery both of clay and soapstone, and traces of mats and other fabrics. The richest localities for archaeologic finds are the eastern shore of Eastern Branch, the Maryland shore of the 
Potomac near Cabin John and Little Falls, Virginia shore at Chain Bridge, opposite Analostan Island, and near mouth of Four-mile Run, the quartzite workshop along Piney Branch, and soapstone quarries near Tennallytown and Falls Church.

Holmes, W. H.

\section{BIBLIOGRAPHY.}

A quarry workshop of the flaked-stone implement makers in the District of Columbia.

Am. Anthropologist 3, No. 1, Jan., 1890, pp. 1-26, Pls. 1-4.

On Piney Branch near Rock Creek. Brief note on further work, pp. 224-5.

Excavations in an ancient soapstcne quarry in the District of Columbia.

Am. Anthropologist 3, No. 4, Oct., 1890, pp. 321-330.

Rose Hill Quarry near Tennallytown.

Distribution of stone implements in the tidewater country.

Am. Anthropologist 6, No. 1, Jan., 1893, pp. 1-14, Figs. 1-2, Pls, 1-2.

Kengla, Louis A.

Contributions to the archaeology of the District of Columbia.

An essay to accompany a collection of aboriginal relics presented for the Toner medal, 1882.42 pp., 5 pls., 1 map.

Washington, R. A. Waters \& Son. 1883.

Mason O. T., et al.

The Aborigines of the District of Columbia and the lower Potomac-A Symposium, under the direction of the vice president of section D.

The American Anthropologist, Vol. II, 1889, pp. 225-266, Pls. I-VII, 1 small figure (map).

Consists of:

Introduction by Otis T. Mason, pp. 225-227.

The Geologic antecedents of man in the Potomac Valley. By W. J. McGee, pp. 227-234.

The paleolithic period in the District of Columbia. By Thomas Wilson, pp. 235-241. Pls. I-IV.

Ancient village sites and aboriginal workshops in the District of Columbia. By S. V. Proudfit, pp. 241-246, Pl. V.

Pottery of the Potomac Tide-water region. By W. H. Holmes, pp. 246-252, Pl. VI.

The shell mounds of the Potomac and Wicomico. By Elmer R. Reynolds, pp. 252-259, 1 map.

Indian tribes of the District of Columbia. By James Mooney, pp. 259-266, Pl. VII. 
Mason, Otis T.

The archaeology of the Potomac Tide-water region.

Proc. U. S. Nat. Mus. 12, pp. 367-370, Pls. 15-17, 1 fig., 1890.

Proudfit, S. V.

Note on the turtle-back celt.

Am. Anthropologist 1, No. 4, Oct., 1888, pp. 337-339.

Work of Indians not of paleolithic man.

A collection of stone implements from the District of Columbia. Proc. U. S. Nat. Mus. 13, pp. 187-194, Pls. 10-14, 1890.

Tooker, W. W.

On the meaning of the name Anacostia.

Am. Anthropologist 7, No. 4, Oct., 1894, pp. 389-393.

Derived from words meaning "at the trading town."

Wilson, Thomas.

The paleolithic period in the District of Columbia.

Proc. U. S. Nat. Mus. 12, pp. 371-376, Pls. 18-21, 1890.

\section{ACKNOWLEDGMENTS.}

The writer wishes to express his great appreciation of the following courtesies: for reading the whole manuscript of the preceding pages to $\mathrm{Mr}$. William Palmer; for reading various sections, to Dr. Walter Hough, Mr. E. A. Preble and Mr. P. L. Ricker. 


\section{DISTRIBUTION OF LIFE IN THE DISTRICT OF COLUMBIA REGION.}

THE PIEDMONT PLATEAU AND COASTAL PLAIN AS FAUNAL AND FLORAL PROVINCES.

In previous chapters some reference has been made to species characteristic of the Piedmont Plateau and of the Coastal Plain. The common boundary of these physiographic provinces is known as the fall line, and its significance as a line of separation of faunas and floras is well worth fuller consideration.

No matter where the naturalist may carry on his researches, he finds species that are near or at the limit of their range. One species leaves off at a certain place, another presses a little farther on; the observer finds himself at the northern limit of some forms, and at the eastern or western or southern limit of others.

The problem of defining boundaries that seem significant because of their nearly or quite coinciding with a sufficient percentage of the totality of range limits usually is a most difficult one. To illustrate the case by local instances, it may be noted that present information indicates among others the following terminations of range as the Potomac Piver is ascended:

Marshall Hall-Taxodium distichum, Polypremum procumbens, Pluchea camphorata.

Hunting Creek-Sabbatia dodecandra, Micranthemum micranthemoides, Ctricularia macrorhiza.

Little River Marshes-Echinochloa walteri, Jussiaea decurrens, Cyperus erythrorrhizos, Cyperus michauxianus, Hyla evittata.

New Cut Road-Liquidambar styraciflua.

Chain Bridge Flats-Sagittaria rigida, Zizania aquatica, Scirpus debilis, Quercus prinoides.

Great Falls-Rhynchospora corniculata, Carex decomposita, Quercus michauxiana, Rumex verticillatus, Paronychia dichotoma, Ilex decidua. 
Seneca Creek-Quercus digitata, Quercus phellos, Tecoma radicans.

In the reverse direction there is a similar graduation in the ranges of the upland forms, for instance:

Great Falls-Asplenium montanum, Rhus aromatica, Viburnum pubescens.

Stubblefield Falls-Betula lenta.

Little Falls-Baptisia australis, Lathyrus venosus, Ceanothus ovatus, Allium cernuum, Eupatorium altissimum, Rulbeckia triloba, Coreopsis tripteris.

Rosslyn-Bicuculla canadensis, Bicuculla cucullaria, Cornus alternifolia, Solidago canadensis.

Marshall Hall-Cystopteris fragilis, Athyrium pycnocarpon.

Occoquan-Pinus strobus, Tsuga canadensis, Rhododendron maximum.

Charles County, Md.-Quercus imbricaria.

If the whole catalogue of plants were searched for such records, and the whole body of other organisms laid under contribution, there would hardly be a rod of ground along the Potomac that would not be distinguished as the farthest point in the upward or downward extension of some species. No doubt a similar condition exists with reference to species whose chief ranges lie to the east and to the west of this region.

As previously remarked, this state of affairs makes it dificult to point out significant lines between distributional areas. In a country without salient topographical features the odds against success are practically prohibitive. Where natural barriers exist the task is more hopeful. A barrier does exist in the vicinity of Washington, and its importance is such that the distribution of life of this area cannot be properly conceived nor adequately discussed without taking cognizance of it. This barrier and boundary line, or rather zone, is the common border of the Atlantic Coastal Plain and the Piedmont Plateau usually referred to as the Fall Line.

So far as it conveys the idea of a sharp division between physiographic provinces, the term Fall Line is a misnomer. 
Indefinite and often ill-defined, the meeting place of these provinces-that higher bench at the foot of the Allegheny Mountain system, known as the Piedmont Plateau, and the lower land or Coastal Plain composed of materials ${ }^{35}$ carried down from the plateau and westward areas and marine sediments deposited during its sereral submergences below sea-level-is better called a zone, a zone of interdigitation.

The irregular character of the boundary between the surfical deposits of the two provinces is due to two causes: (1) the rocks of the Piedmont are exposed eastward beyond the line of their higher outcrops by the erosion of stream valleys; and (2) westward of this line Coastal Plain formations mantle the divides between such streams, sometimes to a distance of several miles. Hilltops far back in the Piedmont province bear caps of Coastal Plain deposits, an indication of the former extent of these sediments and of the vast amount of erosion necessary to have carried off the remainder of them. The reverse condition-that is, islands of Piedmont rocks in the Coastal Plain, does not exist for the reason that the rock surface dips steeply and is now exposed as far as the base-levelling action of the streams makes possible.

The Piedmont Plateau originally was a shore line against which the Coastal Plain sediments were deposited and in its superficial characters, the boundary zone between these provinces still retains many of the characters of a strand. The upper border of this zone is undulating, suggesting the tongues of sand left on the beach by the last tide, the exposed rocky stream beds resemble the gullies cut here and there in the sand by the receding water, while the Coastal Plain debris capping the hills, is like the drift cast up by storm tides, patches of which hither and yon have not yet been washed back to the sea that upheaved them.

\footnotetext{
35 The sedimentary deposits which make up the Coastal Plain are chiefly clays, gravels and sands, which, with the exception of some sandstones, are unconsolidated. The estuarine streams of this region have broad open valleys with muddy vegetation-covered banks. The streams of the Piedmont Province, on the contrary, flow in narrow gorges cut into and usually across the structure of the metamorphic and igneous rocks. These rocks include granite gneiss, gneiss, schist, soapstone, serpentine, diorite and gabbro.
} 
For expression, in a single line, of the boundary of the Piedmont Plateau and the Coastal Plain in the region of the District of Columbia, the line of the present easternmost outcrops of the metamorphic rocks (shown as a heavy line on map, which see, p. 61) will do as well as any. It does not coincide with a line connecting the principal waterfalls, for which the line is named, since these generally are some distance back from the actual edge of the outcrops.

The boundary between Coastal Plain and Piedmont floras and faunas agrees well with the outcrop line north of the Potomac. Roughly the Potomac itself then becomes the boundary as far down as the great bend north of Fredericksburg, where the river cuts its way across the Coastal Plain. However, the Coastal Plain is recognizable as a tangible type on the Virginia side comprising the flood plain of the river and its tributaries. The hills have a prevailing Piedmont biota. Nevertheless, one must be prepared to find some Coastal Plain species accompanying their native geologic formations which cap the hills near the river. Conspicuous patches of these formations lying farther back are shown on the map by heavy broken lines.

The Fall Line as a Faunal and Floral Line.

Be it ever so indefinite and ill-defined, the fall-line must be recognized as having some significance as a faunal and floral line because it lies between regions that have had very distinct geological histories. A succinct sketch of this history may be quoted from W. J. McGee, who says:

"Today there is a lowland plain rising gently from the Atlantic and stretching mountainward to the elbow of the Delaware at Trenton and Philadelphia, to the embouchure of the Susquehanna into Chesapeake Bay, to the great elbow of the Potomac at Washington and Alexandria, to Fredericksburg, and to the bend of the James at Richmond. This lowland plain widens from a point at Sandy Hook to 150 miles at Cape Hatteras. Still further westward there lies an upland plain, 10 to 100 miles wide, overlooking the lowlands and overlooked by the mountains. Along the common boundary of the lowlands and the uplands the land surface drops from a mean altitude of 300 feet to less than 100 feet, 


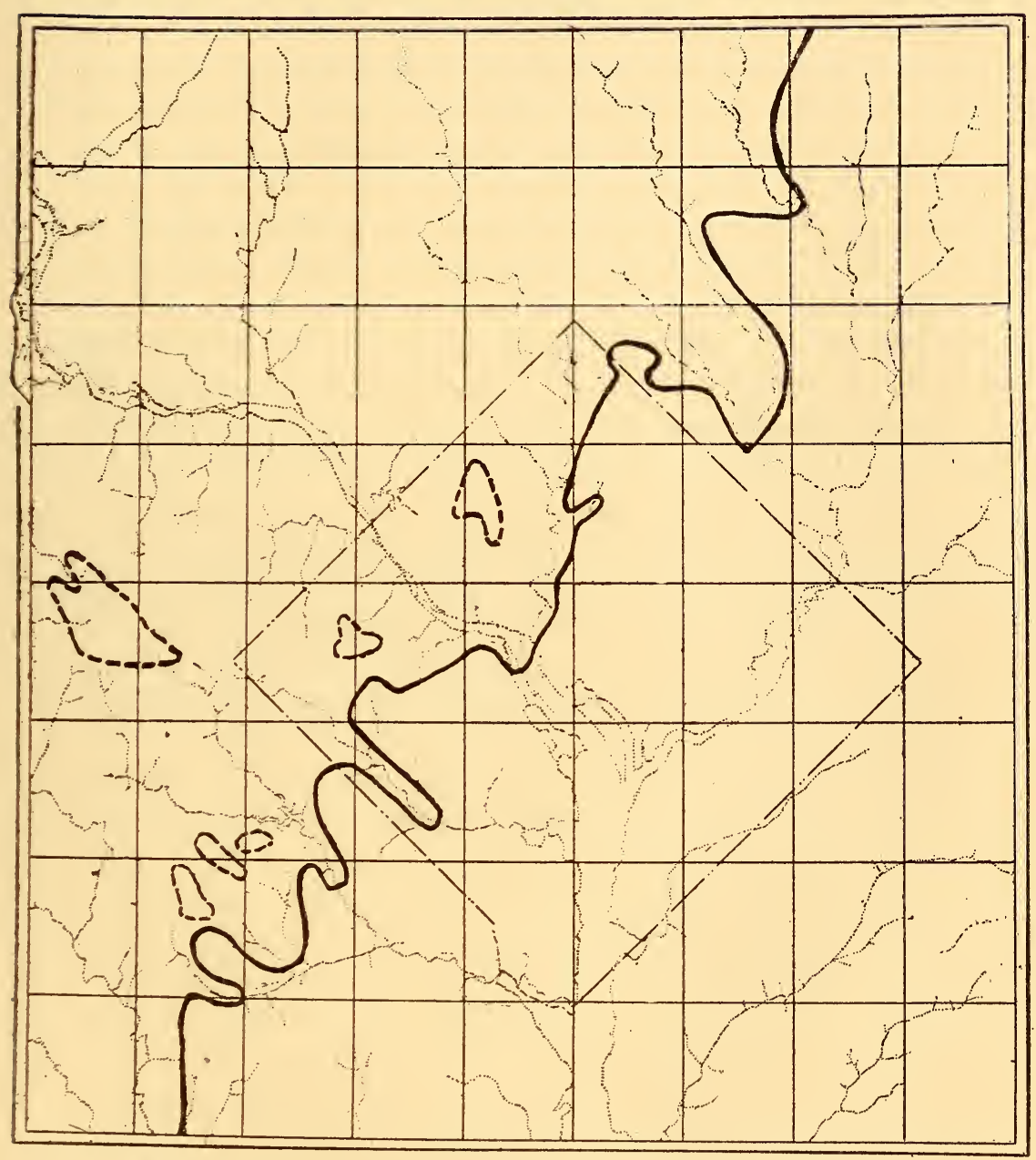

The Piedmont Plateau and the Coastal Plain in the vicinity of the District of Columbia. Solid heavy line indicates easternmost outcrops of the metamorphic rocks. Broken heavy lines show the positions of important isolated bodies of Coastal Plain Deposits. Stream courses are dotted. 
and the rivers cascade from narrow rock-bound gorges into broad tidal (p. 230) estuaries. Now, during the Columbia period, ocean water overwhelmed nearly all of the lowlands between the present coast and the fall line and washed the upland margin where now stand Fredericksburg, Washing. ton, Baltimore, and Philadelphia ; and north of Philadelphia it swept still further inland, submerging the uplands to 300 and even 450 feet above present tide level. Then the Potomac embouched into open ocean at the "Three Sisters"; at the culmination of the submergence, shoal ocean-waters rolled over the highest land between Washington and the coast, and the Anacostia, the Patuxent, and Chesapeake Bay were not; while during even the inferior stages of water the lower Potomac was an estuary many times broader and deeper than today." 36

The greater part of the Piedmont Plateau remained a land surface while the Coastal Plain was submerged several times. Not only was all land life on the Coastal Plain entirely extirpated during these submergences, but even during the emergences ecologic conditions for long periods anc over great areas were radically different from those on the Plateau.

'The tide flats, the salt marshes, the low-lying flood-plains of the rivers which long characterized the landscapes after each emergence were not suited to the needs of most of the upland species. On the contrary, the land was occupied and held by species already adapted to the conditions. As the Coastal Plain was elevated after the last depression, upland species gradually advanced upon it, but to accomplish this they needed powers of migration and the ability to take and hold a place in the face of probably somewhat adverse conditions. Not all species were able to do this, and some, on account of lack of adaptiveness, or small ability to extend their ranges, required a very long time to reach, or may not yet have reached, places in the coastal Plain ecologically suited to them. Conversely, certain other species found only in the Coastal Plain the conditions neces-

36 The American Anthropologist, Vol. II, 1879, pp. 230-231. 
sary to their welfare, as for instance the strand, salt marsh and pine barren plants, or for other reasons never were able to advance from the Coastal Plain to the uplands. It is obvious, therefore, that for reasons of geological history, if for no other, the fall-line must be granted some importance as a faunal and floral boundary.

Inspection of the remarks upon distribution in the "Plant Life of Maryland" ${ }^{37}$ reveals that approximately $163^{38}$ (out of a total of 1,400 ) species of plants are restricted to the Coastal Plain, while 46 others are chiefly so. Corresponding figures for the Piedmont Plateau are 175 and 48 . Search through the local herbarium for the District of Columbia region shows that out of a total of some 1,600 species 193 occur only on the Coastal Plain, and 86 others do not extend far upon the Piedmont. Similar statistics for the latter area are 308 and $76 .{ }^{39}$

Thus from 24 to 31 per cent of the plants of Maryland and the District of Columbia region are restricted in distribution either to the Coastal Plain or the Piedmont Plateau, and an additional 6 to 11 per cent do not far overstep the boundary of these provinces.

Lists of the most characteristic or best known species of the District of Columbia region are subjoined. In addition to these most of the species listed further on for Falls Church, Plummers Island, Little Falls and Great Falls also pertain to the Piedmont and those for the Magnolia bogs, and for Beltsville, Odenton, Hollywood, Riverdale, Hyatts. ville, Bladensburg, Benning and Hunting Creek mostly are characteristic of the Coastal Plain.

\footnotetext{
3 Special Publication 3, Maryland Weather Service, 1910, 533 pp.

as Halophytes are not excluded from this number, since of the 32 listed by Shreve (op. cit. pp. 83-85), 11 reach the Washington area. The reduction in variety of halophytes, as one proceeds from the coast toward the Piedmont Plateau is gradual. If the fall line were farther west some of these plants would range farther in that direction. The distribution of fishes points to the same conclusions.

The figures for the Washington area are incomplete because the collections are not entirely worked up. For permission to use the herbarium the writer is indebted to Messrs. W. R. Maxon and P. C. Standley. The unfinished manuscript of the new catalog of the Washington flora also was kindly put at my disposal by Professor A. S. Hitchcock.
} 


\section{SELECTED SPECIES OF THE WASHINGTON FLORA THAT APPARENTLY ARE RESTRICTED TO THE PIEDMONT PJAATEAU.}

Osmunda claytoniana

Pteretis nodulosa

Woodsia obtusa

Filix bulbifera

Dryopteris clintoniana

goldiana

hexagonoptera

marginalis

Camptosorus rhizophyllus

Asplenium pinnatifidum

trichomanes

montanum

Athyrium thelypteroides

Pellaea atropurpurea (in natural situations)

Cheilanthes lanosa

Selaginella rupestris

Isoetes engelmannii valida

Pinus strobus

pungens

Tsuga canadensis

Panicum gattingeri

linearifolium

xalapense

annulum

latifolium

Muhlenbergia sobolifera

schreberi

Brachyelytrum erectum

Eragrostis hypnoides

capllaris

frankii

Melica mutica

Uniola latifolia

Festuca obtusa

Bromus purgans incanus

Elymus striatus

Hystrix hystrix

Hemicarpha micrantha

Fimbristylis baldwiniana

Scirpus planifolius

lineatus
Carex nigro-marginata

jamesii

frankii

davisi

albursina

hirtifolia

careyana

platyphylla

oligocarpa

hitchcockiana

torta

Arisaema dracontium

Commelina erecta

Melanthium latifolium

Allium tricoccum

cernuum

Erythronium albidum

Lilium philadelphicum

Vagnera stellata

Trillium sessile grandiflorum

Iris cristata

Sisyrinchium intermedium mucronatum

Cypripedium parviflorum

Blephariglottis peramoena

Triphora trianthorphora

Liparis loesellii

Corallorhiza wisteriana

Betula lenta

Populus virginiana

Quercus acuminata leana

Hicoria cordiformis microcarpa ovata

Ostrya virginiana

Celtis crassifolia

Cerastium oblongifolium

Silene alba

Delphinium tricorne

Aconitum uncinatum

Anemone virginiana 
Anemone quinquefolia

Clematis viorna

Trautvetteria carolinensis

Ranunculus septentrionalis

Thalictrum caulophylloides revolutum

Caulophyllum thalictroides

Jeffersonia diphylla

Bicuculla canadensis

Dentaria diphylla

Arabis dentata canadensis patens

Sedum telephioides

Mitella diphylla

Ribes rotundifolium

Aruncus aruncus

Rubus odoratus

Agrimonia gryposepala

Baptisia australis

Trifolium reflexum

Stylosanthes biflora

Meibomia pauciflora

Meibomia grandiflora bracteosa

Lathyrus venosus

Oxalis grandis

Ptelea trifoliata

Polygala senega

Tithymalus commutatus

Tithymalopsis paniculata

Chamaesyce preslii

Floerkea proserpinacoides

Rhus aromatica

Euonymus atropurpureus

Staphylea trifolia

Acer saccharum

Impatiens aurea

Ceanothus ovatus

Vitis rupestris

Hypericum prolificum

Viola conspersa

pallens

grandis

filicetorum

striata

Cubelium concolor
Dirca palustris

Oenothera prasina

Panax quinquefolium

Heracleum lanatum

Sanicula marylandica gregaria

Erigenia bulbosa

Zizia aurea

Taenidium integerrima

Cornus alternifolia stolonifera

Rhododendron maximum

Steironema hybridum

Dodecatheon meadia

Obolaria virginica

Phlox subulata divaricata

Polemonium reptans

Hydrophyllum canadense virginicum

Ellisia nyctelea

Phacelia covillei purshii

Mertensia virginica

Lithospermum canescens

Isanthus brachiatus

Scutellaria saxatilis

incana

serrata

versicolor

Monarda clinopodia

Blephilia hirsuta

Clinopodium vulgare

Koellia clinopodioides verticillata

Penstemon penstemon

Leptandra virginica

Mecardonia acuminata

Dasystoma virginica

Veronica americana scutellata

Utricularia gibba

Conopholis americana

Ruellia strepens

Viburnum pubescens

Diervilla diervilla

Triosteum perfoliatum 
Valeriana pauciflora

Valerianella chenopodifolia woodsiana

Campanula americana

Adopogon dandelion

Hieracium paniculatum

Eupatorium altissimum sessilifolium urticifolium verticillatum

Laciniaria scariosa

Solidago flexicaulis racemosa

canadensis

rigida

rupestris

Aster oblongifolius

shortii

concinnus

cordifolius

corrigiatus

curvescens

oviformis

ericoides pilosus schreberi

umbelliformis

gracilescens

phlogifolius

sagittifolius

sylvestris

tradescanti

Erigeron philadelphicus

Antennaria solitaria

Polymnia canadensis

Silphium trifoliatum

Chrysogonum virginianum

Rudbeckia triloba

Helenium nudiflorum

Heliopsis helianthoides

Rudbeckia fulgida

triloba

Helianthus divaricatus dowellianus

Coreopsis tripteris

Mesadenia reniformis

Senecio pauperculus smallii

Cirsium virginianum

Some well-known species which are chiefly confined to the Piedmont but which range more or less upon the Coastal Plain are:

Osmunda claytoniana

Lycopodium clavatum

Chamaelirium luteum

Lilium canadense

Erythronium americanum

Unifolium canadens?

Juglans cinerea

Quercus imbricaria

Cimicifuga racemosa

Aquilegia canadensis

Hepatica hepatica

Sanguinaria canadensis

Heuchera americana
Saxifragá virginiensis

Hydrangea arborescens

Hamamelis virginiana

Opulaster opulifolius

Cercis canadensis

Panax trifolia

Aralia nudicaulis

Pyrola spp.

Sabbatia angularis

Collinsonia canadensis

Dianthera americana

Viburnum cassinoides

Senecio aureus 


\section{SELECTED SPECIES OF THE WASHINGTON FLORA THAT APPARENTLY ARE RESTRICTED TO THE COASTAL PLAIN.}

Lygodium palmatum

Dryopteris simulata

Anchistea virginica

Lycopodium adpressum

carolinianum

Isoetes saccharata

Pinus taeda

Taxodium distichum

Potamogeton amplifolius compressus robbinsii

Lophotocarpus calycinus

Sagittaria subulata longirostra

Erianthus saccharoides

Paspalum longipilum psammophilum

Echinochloa walteri

Panicum condensum mattamuskeetense spretum

columbianum thinium

ensifolium

virgatum cubense

stipitatum

verrucosum

clutei

lucidum

lanuginosum

pseudopubescens

addisoni

oligosanthes

scoparium

aculeatum

Chaetochloa geniculata

Cenchrus carolinianus

Aristida gracilis

Muhlenbergia schreberi palustris

Alopecurus geniculatus

Uniola laxa

Panicularia obtusa pallida

Festuca octoflora myuros
Bromus villosus

Elymus striatus arkansanus

Cyperus fuscus

microdontus

rotundus

erythrorhizos

retrofractus

Eleocharis ochreata

olivacea

quadrangulata

Scirpus fluviatilis

sylvaticus

Fuirena hispida

Rhynchospora macrostachya

axillaris

gracilenta

Scleria triglomerata

Carex gracillima

conjuncta

canescens disjuncta

bromoides

incomperta

lanuginosa

vestita

lacustris

folliculata

intumescens

collinsii

abscondita

glaucodes

debilis

oblita

typhinoides

louisianica

rostrata

bullata

swanii

styloflexa

Eriocaulon decangulare

Chrospermum muscaetoxicum

Melanthium virginicum

Stenanthium robustum

Tofieldia racemosa

Dioscorea paniculata 
Iris verna

Sisyrinchium atlanticum

Perularia flava

Blephariglottis blephariglottis

Pogonia ophioglossoides

Ibidium odoratum

Limodorum tuberosum

Ophrys australis

Acnida cannabina

Chenopodium boscianum

Cabomba caroliniana

Magnolia virginiana

Ranunculus obtusiusculus sceleratus

Roripa sylvestris

Radicula hispida

Sarracenia purpurea

Itea virginica

Aeschynomene virginica

Stylosanthes riparia

Meibomia rigida

Lathyrus palustris

Strophostyles missouriensis

Polygala lutea curtissii

Tithymalopsis arundelana ipecacuanhae

Ilex glabra

Ascyrum stans

Vicla brittoniana nepetaefolia

Ammannia koehnei

Rhexia virginica mariana

Ludwigia hirtella

Jussiaea decurrens

Oenothera laciniata
Oenothera sinuata

Myriophyllum spicatum

Clethra alnifolia

Kalmia angustifolia

Steironema lanceolata

Polypremum procumbens

Sabbatia dodecandra

Bartonia paniculata

Gentiana saponaria

Koellia virginiana

Lycopus uniflorus

Gratiola sphaerocarpa

Agalinis setacea

Otophylla auriculata

Micranthemum micranthemoides

Utricularia subulata juncea

Plantago aristata nuttallii cordata

Oldenlandia uniflora

Viburnum nudum

Eupatorium hyssopifolium

cannabinum

maculatum

serotinum

Erigeron ramosus

Pluchea camphorata

Solidago elliottii

odora

puberula

Aster concolor

dumosus

radula

Helianthus angustifolius

mollis

giganteus

Bidens connata

Some well-known species which are chiefly confined to the Coastal Plain but which range more or less upon the Piedmont ${ }^{40}$ are:

Lorinseria areolata

Typha angustifolia

Rhynchospora corniculata

Zizania aquatica

Orontium aquaticum

Peltandra virginica

\footnotetext{
${ }_{40}$ Scarcely any of them reach the Piedmont in Pennsylvania or northern New Jersey.-Witmer Stone.
} 
Myrica carolinensis

Quercus digitata

phellos

lyrata

michauxiana

prinoides

Phoradendron flavescens

Drosera spp.

Liquidambar styraciflua

Clitoria mariana

Ilex opaca

\author{
Ilex laevigata \\ decidua \\ Hibiscus moscheutos \\ Opuntia opuntia \\ Aralia spinosa \\ Leucothoe racemosa \\ Pieris mariana \\ Monarda punctata \\ Tecoma radicans \\ Baccharis halimifolia \\ Arnica nudicaulis
}

To put in another way the facts of plant distribution with reference to the Fall Line, it is evident that plants which prefer the higher elevations, that can exist only upon rock outcrops (including such well-known controllers of vegetation as limestone and serpentine), or in the vicinity of waterfalls, or that thrive best in deep humus, loams and clays, are chiefly restricted to the Piedmont. On the other hand, plants of the beaches, salt marshes, tide flats, pine barrens, and magnolia bogs and those that prefer lower elevations and such soils as sand and sandy loams are found almost exclusively in the Coastal Plain. ${ }^{41}$

In general the conditions tend to restrict most of the aquatic and semi-aquatic groups to the Coastal Plain. Thus this province has the lion's share of Potamogeton, Sagittaria, and of grasses and sedges in general, although such large genera as Panicum and Carex are more evenly divided. A number of other genera, as Quercus, Meibomia, Eupatorium, and Solidago also are about halved by the two regions. However, some groups show a distinct preference for the Piedmont, including the ferns, Ranunculaceae, Berberidaceae, Arabis, Saxifragaceae and Araliaceae. On the whole the series of plants which produce the early spring show of flowers pertain to the Piedmont rather than to the Coastal

41 Some interesting pairs of species may be cited as indicating the diverse conditions on the Piedmont and Coastal Plain as possible factors in speciation. They are (the Pledmont form in each pair being cited first) : Uniola latifolia, U. laxa; Tofieldia glutinosa, T. racemosa; Iris cristata. I verna; Lathyrus venosus L. palustris; Stylosanthes biflora, S. riparla; Aralia racemosa, A. spinosa; Steironema hybridum, S. lanceolatum; Viburnum cassinoides, V. nudum; Helianthus divaricatus, H. mollis; and Senecio aureus and $\mathrm{S}$. tomentosus. 
Plain, perhaps for one reason on account of richer accumulations of humus.

We have seen that the potency of ecologic requirements and of historical factors are such that about a third of the entire flora of the Washington area is confined (or nearly so) to one side of the Fall Line or the other. ${ }^{42}$ In proceeding from this conclusion to consideration of the part played by the Fall Line in delimiting faunal elements, we must recall not only the great diversity in edaphic conditions between the Piedmont and the Coastal Plain, but also the divergence between the more complete ecologic surroundings of animal life that consist of these conditions added to and modified by vegetation.

Plants and plant associations have great influence on animal life, and the presence or absence of certain plants is the determining factor in the distribution of numerous animals. This is especially true of insects, various species of which breed exclusively upon single host species. Such forms are frequent among the jumping plant lice (Psyllidae), ordinary plant lice (Aphidae), scale insects (Coccidae), leafhoppers (Jassidae), lace bugs (Tingidae), leaf bugs (Miridae), leaf beetles (Chrysomelidae), long-horned beetles (Cerambycidae), weevils (Rhynchophora), and butterflies and moths (Lepidoptera).

The influence of the different conditions above and below the fall line, upon another group of insects, the Orthoptera, members of which are not so restricted in feeding habits, as those mentioned, is brought out in a paper by Rehn and Hebard. ${ }^{43}$ They record 47 species as pertaining chiefly to the Piedmont, 101 to the Coastal Plain, while only 52 range generally over both areas.

Ulke lists ${ }^{44} 23$ species of beetles of austroriparian and 14

\footnotetext{
${ }^{42}$ In this connection note R. M. Harper's statement that "The rather vaguely defined 'Austroriparian area' of some botanists-or rather biologists-is practically the coastal plain, and the boundary between that and the 'Carolinian area' is simply the fall-line, the cause of which is purely geological, and not climatic." (Bul. Torrey Botanical Club, 31, No. 1, Jan., 1904, p. 10).

43 Rehn, J. A. G., and Hebard M. Studies in the Dermaptera and Orthoptera of the Coastal Plain and Piedmont Region of the Southeastern United States. Proc. Ac. Nat. Sci., Philadelphia, 68, 1916, pp. 87-314, Pls. 12-14.

14 Proc. U. S. Nat. Mus., 25, 1902, pp. 3-4.
} 
of alleghenian affinities, another way of saying that in this region they are restricted to the Coastal Plain and Piedmont Plateau respectively. Among hymenoptera, the following, I am informed by Mr. H. L. Viereck, are confined to the Coastal Plain: Perdita novi-angliae, P. halictoides, Andrena miserabilis, Bombius scutellaris, Pepsis clegans, Stictia carolina, and Bembix cinerea. Knowledge of the local distribution of these and other groups of insects is not so detailed as in the case of the Orthoptera. If it were, statistics as to their relation to the fall line would no doubt be fully as impressive.

A similar distinction between the life of the Piedmont Plateau and the Coastal Plain is not so clearly reflected in the higher groups such as mammals and birds. Nor should it be expected. Both of these orders are much better equipped for migratory movements than either plants or insects and both are adaptable to a greater range of conditions. However, some slight effect can be traced even in these higher groups. The wood rat, for instance, is certainly confined to the Piedmont, and the red squirrel seems not to venture much beyond. The woodchuck, chipmunk and otter are more at home in the Piedmont, while among the shrews, Microsorex, so far as known, occurs only on the Piedmont and Sorex fontinalis only in the Coastal Plain.

The birds which as breeding species appear to respond to the differences in conditions on the two great divisions of our area are for the Piedmont: Nighthawk, Worm-eating Warbler, Kentucky Warbler and Bewick's Wren; and for the Coastal Plain: Florida Gallinule, Least Bittern, Bank Swallow, and Long-billed Marsh Wren.

Among batrachians and reptiles Siren lacertina, Hyla evittata, Coluber guttatus, Lygosoma laterale and Malaclemmys centrata belong to the Coastal Plain, while Spelerpes longicaudus, Coluber obsoletus, Crotalus horridus and Clemmys insculpta are Piedmont forms.

The influence of the fall line on the distribution of aboriginal men and its control over city-building and the industries of modern man are interesting topics concerning which the following is quoted from McGee: "Through the Potomac 
Valley passes one of the most strongly marked geologic and cultural boundaries on the face of the earth. * * * It is known to students of modern manufactures as the fall line because along it the rivers descend as abruptly as the land; and it is even more notable as a line of deflection than as one of declivity in rivers. The great waterways of the Middle Atlantic slope maintain their courses through Appalachian ranges and Piedmont hills alike; but on reaching the coastal lowlands they are turned aside literally by a sand bank ${ }^{45}$ little higher than their depth, and thence hug the upland margin for scores of miles before finally finding their way into the ocean. So the coastal lowlands are nearly isolated by the tidal bays and river-elbows along their inner margin. Measured along the fall line, the Hudson is barred from the Rappahannock, 300 miles southward, by only 60 miles of land and unnavigable water. This remarkable physiography is now and ever has been reflected in the culture of the region. The pioneer settlers of the country ascended the tidal canals to the falls (p. 233) of the rivers, where they found, sometimes within a mile, clear, fresh water, the game of the hills and woodlands, and the fish and fowl of the estuaries, and, as the population increased, abundant water-power and excellent mill-sites, easy ferriage, and practicable bridge-sites; here the pioneer settlements and villages were located; and across the necks of the inter-estuarine peninsulas the pioneer routes of travel were extended from settlement to settlement until the entire Atlantic slope was traversed by a grand social and commercial artery stretching from New England to the Gulf States. As the population grew and spread, the settlements, villages, and towns along the line of Nature's selection waxed, and many of them yet retain their early prestige; and the early stageroute has become a great metropolitan railway and telegraph route connecting North and South as they were connected of old in more primitive fashion. And just as these natural conditions influenced the white invader, so, and even

${ }^{45}$ In this connection the effect of the tidal character of streams below fall line, and consequent absence of powerful eroding currents should not be overlooked. 
more strongly, must they have influenced the migrations, settlements, industries, and character of the aboriginal monarchs of the Potomac waters and woodlands." 46

\section{The Fall Line as a Barrier.}

The fall line has importance as an actual barrier to the spread of the fauna of the streams which cross it, since they are uniformly characterized by abrupt descent. The following illustrates this influence: of the 80 species of fishes known to be native to the region of the District of Columbia, $S$ which ascend the river to spawn are stopped either by Little Falls or Great Falls. Fourteen others are so dependent upon Coastal Plain conditions that they never ascend the river even as far as the falls. In other words, more than one-fourth of the native fish fauna is confined to the Coastal Plain. Three species of fishes, namely, the brook trout, trout perch. and Miller's thumb, appears to be confined to waters above the fall line.

These various categories of species are given in full in the following lists. What effect, if any, the fall line has upon the distribution of other aquatic creatures is unknown. ${ }^{47}$

Salt water fishes coming within the Washington area.

Carcharhinus obscurus

Brevoortia tyrannus

Stolephorus mitchilli

Cyprinodon variegatus

Tylosaurus marinus

Siphostoma fuscum

Orthopristus chrysopterus
Leiostomus xanthurus

Menticirrus saxatilis

Chaetodipterus faber

(robiosoma bosci

Opsanus tau

Prionotus carolinus

Achirus fasciatus

Fishes ascending river to Little Falls.

Acipenser sturio brevirostris
P'omolobus mediocris pseudoparengus aestivalis

48 The American Anthropologist, Vol. II, 1879, pp. 233-234. W. J. McGee.

${ }^{47}$ Except for a few reptiles and batrachians previously cited. 
Fishes ascending river to Great Falls. Alosa sapidissima Morone americana Roccus lineatus

Fishes occurring only in the Piedmont. Salvelinus fontinalis Cottus meridionalis Percopsis omiscomaycus

\section{BIBLIOGRAPHY.}

Darton, N. H., and Keith, Arthur.

Description of the Washington Quadrangles. Geologic atlas of the United States. Washington Folio. 1901. pp. 1-7.

Miller, B. L., Bonsteel, J. A., Alexander, W. H., Newell, F. H., Bauer, L. A., and Besley, F. W.

Maryland Geological Survey. Prince George's County. 1911. 251 pp., 13 pls., 3 figs. Topographical and geological maps in separate cover.

Contains an extensive bibliography, pp. 33-68, many of the citations in which relate to the coastal plain.

Clark, W. B., and Miller, B. L.

The Physiography and Geology of the Coastal Plain Province of Virginia, with chapters on The Lower Cretaceous, by E. W. Berry, and The Economic Geology, by T. L. Watson. Bul. No. IV, Virginia Geological Survey, 1912, 274 pp., 19 pls., 1 fig., geological map.

Like the preceding this publication contains a valuable bibliography, pp. 19-45.

\section{MAGNOLIA BOGS NEAR WASHINGTON, D. C., AND THEIR RELATION TO THE PINE BARRENS.}

In treating the types of collecting grounds in the District of Columbia region, a task to which this chapter and the next are devoted, it is easiest to begin with an account of the most strikingly characterized areas. In the writer's opinion this distinction clearly belongs in this region to the white sand and gravel bogs, or magnolia bogs, found only in the Coastal Plain formations.

The name Magnolia Bogs is selected for the areas about to be discussed, because it has a certain currency, and because the swamp magnolia or sweet bay (Magnolia vir- 
giniana) probably is not absent from one of them (of any size), something which is not true of any other equally conspicuous plant. These bogs are restricted to Coastal Plain formations, for it is only among those that the surficial deposits give the proper basal conditions. Where a surface layer, usually of coarse white gravel, or of gravel and sand mixed, is underlaid by an impervious layer of clay ${ }^{48}$ and flushed by a constant flow of spring water, there grows without exception, and only there, some combination of the plants which characterize what are here called Magnolia bogs.

Such bogs exist at a number of points along Indian Creek and its continuation the Eastern Branch, as at Ammendale, Hollywood, Riverdale, Hyattsville, Bladensburg, Reform School, Kenilworth and Deanewood. At the head of Brier Ditch, a tributary, similar boggy spots exist at Lanham; on the next tributary to the south are the Carter's Lane and Lygodium bogs; and along Beaver Dam Branch, the Magruder and Sarracenia bogs. On the other side of the valley and flowing into Paint Branch are the four Powdermill bogs (others now drained once existed here) ; and tributary to Northwest Branch the Brookland, Terra Cotta and Takoma bogs. Along Piney Branch and Rock Creek were the two Brightwood bogs, Holmead Swamp, and Magnolia Run Bog. The last four are all in the extreme edge of the main body of Coastal Plain formations. In the bed of, and across the creek from, Holmead and Magnolia Run bogs are exposures of Piedmont Rocks. Along Four-mile Run Valley, near Green Valley, and along the north side of Four-mile Run Hill and Hunting Creek, are similar boggy spots. Bogs of more or less the same nature exist at Laurel, Accotink (?), Suitland, Silver Hill, Surattsville, Savage, Arundel and Odenton. It may well be that a large number of such bogs await discovery.

It is the writer's purpose to describe in some detail the Magnolia bogs with which he is best acquainted, namely, the Powdermill bogs near Paint Branch (2 miles west of Belts-

${ }^{48} \mathrm{By}$ referring to the brief statement (p. 59) of the nature of Coastal Plain and Piedmont deposits, it will be seen that only the former include alternating clays and gravels. 
ville, Md.), and to attempt to throw some light upon a question, inspired by consideration of these bogs, that is: Why we have no pine barrens in our region, nor indeed anywhere in the Maryland Coastal Plain?

By way of introducing what at first thought may impress the reader as rather unrelated topics for discussion, I present a quotation relating to the Pine Barrens of New Jersey, from Dr. Witmer Stone, than whom there is no closer student of the Pine Barrens of that State, and with whom the writer esteems himself fortunate to have made two visits to this most interesting region.

In his account of Polygala lutea, in that model local flora, "The Plants of Southern New Jersey," 49 Dr. Stone says: "This is one of the showiest plants of the Pine Barrens, one of those that render the region so strikingly different from the uplands beyond the fall line. I well remember my first visit to the Pines, when the low moist spots were all dotted with the brilliant heads of the polygala, with here and there stalks of white-fringed orchis, and the small orange-fringed orchis, so like the Polygala in color, with Xyris and Eriocaulon and a host of other things hitherto unknown. The mosquitos and heat were nothing when such a natural flower garden lay before one's eyes, and the poor flora of my upland pastures seemed to sink into insignificance beside such riches."

Dr. Stone has here given us a vivid picture of his first impression of the Pine Barrens, and when the reader realizes that the same combination of plants Dr. Stone mentions may be seen in our own Magnolia bogs, as those at Odenton and Suitland, the query will seem less strange-why have we no pine barrens?

To proceed with the details of the discussion, which necessitates description of typical Magnolia bogs, I will begin with the general surroundings of " $\mathrm{my}$ favorite group-the Powdermill Bogs. These lie near the here sharply defined inner border of the Coastal Plain, and two of the four indeed lie on top of what is really a Piedmont Hill. The Coastal Plain country here is strikingly different from the

${ }^{49}$ Ann. Rep. N. J. State Museum, 1910 (1911), p. 520. 
Piedmont, in the preponderance of sandy and gravelly soils. For instance, this region is the nearest to Washington, where one can walk long distances in soft sandy roads-an experience which on some of the hottest days makes a lasting impression concerning the geological and other peculiarities of the Coastal Plain.

As to the general flora of the area, the common oaks are Quercus marilandica, stellata and alba. The pines include Pinus rigida and virginiana, the latter more common; chestnut and chinquapin abound, as do also sweet gum, dogwood and sassafras. The commonest shrubs are mountain laurel, pink azalea, blueberries and huckleberries. Among the herbs, Cypripedium acaule, Polygala incarnata, Baptisia tinctoria, Sarothra gentianoides and Chrysopsis mariana are the most characteristic of the indigenous species. The growth immediately surrounding the Magnolia bogs includes red maple, alder (Almus rugosa), sour gum, holly (Ilex opaca) and Pinus virginiana.

The bogs are fringed, or dotted with clumps of Magnolia virginiana, Myrica, swamp azalea, sheep laurel, Gaylussacia dumosa, Vaccinium corymbosum, Viburnum nudum and cassinoides and other shrubs named in the subjoined list. Around the bases of the shrub colonies are deep cushions of sphagnum in which grow some of our showiest orchids as Pogonia ophioglossoides and Limodorum. The open centers of the bogs, or interspaces between the shrub islands give a view of the surface stratum of these areas-the white gravel, or gravel and sand, flush to the surface or slightly overflowed with clear, cool spring water. In the water grow algae, and the lycopods, Utricularia, Sundews, Tyris, Tofieldia and many other of the plants mentioned below. On the slightest elevations of the gravel are clumps of lichens of the genus Cladonia, here growing in water, though elsewhere seen in the dryest possible situations. ${ }^{50}$

\footnotetext{
${ }^{50} \mathrm{Bog}$ ecologists have invented a sublimated white ribbon conception of physiologically dry water. This brand is so charged with bog extract, it is alleged, that plants living in it do not imbibe so much as of the ordinary kind, hence willy-nilly have a physiologically dry experience. This theory will not serve to explain the presence of Cladonia in Magnolia bogs, however, as the water is constantly flowing and as free from matters in solution as is possible in natural waters.
} 
The aspect and the plant associations of the Magnolia bogs as well as some of their animal inhabitants are unique in our region, and make these areas the objectives of pilgrimages by devotees of all branches of natural history.

LIST OF VASCULAR PLANTS KNOWN TO OCCUR IN THE POWDERMILL BOGS, WITH REMARKS QUOTED FROM STONE ON THE STATUS OF CERTAIN SPECIES IN THE NEW JERSEY PINE BARRENS. ${ }^{.1}$

Osmunda regalis

Pteridium aquilinum

Anchistea virginica

Dryopteris spinulosa

thelypteris

cristata

Lycopodium adpressum

carolinianum

Sagittaria pubescens

Andropogon glomeratus

virginicus

Panicum verrucosum

virgatum cubense

lucidum

microcarpon

mattamuskeetense

ensifolium

Calamagrostis cinnoides

Eleocharis tenuis

Eriophorum virginicum

Fuirena hispida

Rhynchospora alba

glomerata

gracilenta "especially abundant in the Pine Barrens."

"most plentiful in the Pine Barrens."

"one of the most characteristic plants of the bogs of the Pine Barren region."

"a characteristic Pine Barren bog species."

"common throughout the Pine Barrens."

"plentiful in bogs in the Pine Barrens."

"plentiful in the Pine Barrens."

"especially abundant in the Pine Barrens."

"common in bogs of the Pine Barren * * * districts."

"frequent in bogs or swamps of the Pine Barrens * * * here reach. ing the northern limit of its range."

51 Some of these species have no especial relation to the boggy conditions; in other words, they are merely of adventitious occurrence. 
Scleria reticularis

torreyana

Carex leptalea

intumescens

folliculata

Xyris torta (flexuosa)

caroliniana

Eriocaulon decangulare

Juncus effusus

Tofieldia racemosa

Smilax herbacea

Gymnadeniopsis clavellata

Pogonia ophioglossoides

Limodorum tuberosum

Ibidium cernuum gracilis

Myrica carolinensis

Magnolia virginiana

Drosera rotundifolia longifolia (intermedia)

Itea virginica

Rubus hispidus

Sanguisorba canadensis

Aronia atropurpurea nigra

Amelanchier intermedia

Linum virginianum

Polygala cruciata

Rhus vernix

Ilex verticillata laevigata

Ascyrum stans

Hypericum canadense

densiflorum

Viola cucullata

primulifolia

"frequent throughout the Pine Barren * * * Districts."

"Pine Barren swamps, the most plentiful species."

"bogs in the heart of the Pine Barrens, local. This plant is limited to the same area that the Abama inhabits, but is much rarer."

"most plentiful in the Pine Barrens and northern counties."

"frequent in the Pine Barrens."

"most abundant and uniformly distributed in the Pine Barrens."

"common throughout the Pine Barrens."

"frequent in Pine Barren swamps."

"common in damp ground in the Pine Barrens."

"most abundant in the Pine Barrens."

"common in swamps of the Pine Barrens."

"common in the Pine Barrens."

"the most abundant small St. John's Wort found in the Pine Barrens." "plentiful in the Pine Barrens." 
Rhexia virginica

mariana

Oxypolis rigidior longifolia

Nyssa sylvatica

Clethra alnifolia

Azalea viscosa

viscosa glauca

Kalmia angustifolia

Leucothoe racemosa

Pieris mariana

Xolisma ligustrina

Gaylussacia dumosa

Vaccinium corymbosum atrococcum

Bartonia paniculata virginica

Asclepias rubra

Utricularia subulata

Oldenlandia uniflora

Viburnum dentatum

cassinoides

nudum

Eupatorium verbenaefolium rotundifolium

Solidago erecta

aspera

elliottii

"neglecta" ${ }_{52}$

Aster patens

dumosus

puniceus

lateriflorus

radula

antrorsa

Ionactis lineariifolius

Helianthus angustifolius "especially abundant in the Pine Barrens."

"very abundant in the Pine Barrens."

"most abundant in the Pine Barrens."

"very common in the Pine Barrens."

"plentiful throughout the Pine Barrens."

"frequent in the Pine Barrens."

"frequent in the bogs of Pine Barrens."

"common in the Pine Barrens."

"frequent in * * * the Pine Barrens."

"frequent in swamps of the Pine Barrens."

"frequent in the Pine Barrens."

"This is the most common Goldenrod in swamps and bogs of the Pine Barrens."

"frequent in swamps of the Pine Barrens."

${ }^{52}$ One, perhaps two, local forms related to neglecta, appear to need new names. 
From the foregoing list and quotations it is evident that the Powdermill Bogs contain many plants that are abundant in the Pine Barrens. Twenty-six ${ }^{53}$ of the species are among those mentioned by Stone (op. cit., pp. 76-78) as characteristic of the Pine Barren flora and their presence must be regarded as incontestable evidence of relationship. In addition to Pine Barren plants, the Powdermill Bogs, small as they are, ${ }^{54}$ have yielded certain species of insects which previously had been known only from Pine Barrens. ${ }^{55}$ These include a crane-fly (Molophilus novacaesariensis Alexander), a deer-fly (Chrysops brimleyi Hine) and a bee (Dolichochile melittoides Viereck). One other deer-fly (Chrysops vitripennis Shannon) described from these bogs, and a Syrphid (Microdon scitulus Williston) known previously only from Florida, probably pertain to the Pine Barren fauna.

It is worthy of note, also, that a species of shrew (Sorex fontinalis) was described from one of the Powdermill bogs, and that all specimens thus far caught came from similar situations. Synaptomys cooperi, very local in the region, and Condylura cristata also occur in these bogs.

\footnotetext{
63 Four other true pine-barren species are common in the neighborhood. Also 41 other species of the bogs are plentiful in the Pine Barrens.

The largest has less than an acre of actual bog.

${ }^{55}$ Speaking of insects of the New Jersey Pine Barrens, Dr. John B. Smith says: "The species on the whole resemble those of more Southern States and Georgian or even the Floridian forms are not uncommonly met with, and yet the only trace of real boreal species has been found in the deep cold swamps of Ocean County." (The Insects of New Jersey, Ann. Rep. N. J. State Muis., 1909, (1910) p. 30.)

This is eminently true also of the plants of the Pine Barrens, numerous Northern forms here finding their Southern limit (at least so near the coast) among a flora closely related to that of the Southern Atlantic States. Among such Northern species may be mentioned Potamogeton Oakesianus, $P$. confervoides, Sporobolus uniflorous, Carex trisperma, $C$, livida, Hypericum boreale, Corema conradii, Utricularia intermedia, Nemopanthus mucronatus, Solidago uniligulata and Aster memoralis.

In the local Magnolia bogs this element is represented by Dryopteris simulata, Unifolium canadense, Sanguısorba canadensis, Rubus hispidus, Hypericum canadense, Chamaedaphne calyculata (Glenburnie) and Viburnum cassinoides.

The prevailing affinities of the Pine Barren and Magnolia bog floras being austral, such instances of the presence in them of boreal plants weigh against the importance of temperature control. Obviously temperature control cannot restrict to the same small bog, plants, which, on the basis of the climate of their respective ranges, presumably have almost opposite temperature requirements.
} 
As implied in preliminary remarks on the Magnolia bogs, those of the Powdermill group, by no means harbor the whole suite of plant species known from the bogs. It is not pertinent to the present discussion to attempt to list the whole flora of the bogs, but it is sought to include in the following itemization all of the plants of the local Magnolia bogs that are named in the list given by Stone (op. cit., pp. 77-78) of characteristic Pine Barren species.

\section{CHARACTERISTIC PINE BARREN PLANTS KNOWN FROM} MAGNOLIA BOGS IN THE VICINITY OF WASHINGTON. ${ }^{56}$

Dryopteris simulata

Lycopodium adpressum

carolinianum

Sparganium americanum

Erianthus saccharoides

Panicum longifolium ensifolium

clutei

Panicum lucidum

columbianum thinium

Eleocharis tuberculosa

Rhynchospora alba

axillaris

gracilenta

Scleria triglomerata

torreyana

Carex bullata

Xyris caroliniana

Eriocaulon decangulare

Juncus aristulatus
Hollywood, Suitland.

Ammendale, Hyattsville, Deanewood, Kenilworth, Magruder, Lanham, Accotinl.

Magnolia Run.

Terra Cotta, Holmead, Kenilworth, Brightwood.

Hyattsville, Kenilworth.

Hyattsville, Kenilworth.

Riverdale, Lanham, Laurel.

Magnolia Run, Takoma, Brookland.

Takoma.

Howard Hill, Brightwood, Holmead.

Brightwood, Holmead, Magnolia Run.

Hyattsville.

Hollywood, Brookland, Holmead.

Reform School, Kenilworth, Terra Cotta.

Brightwood, Kenilworth.

Hyattsville, Reform School, Sarracenia, Brightwood

Savage, Hyattsville.

Brightwood, Holmead, Takoma.

Kenilworth.

${ }^{56}$ Names of bogs in which species are known to occur are cited by way of authentication, but no effort has been made to give complete particulars in this respect. Occurrences in the Powdermill bogs are not given a second mention. 
Tofieldia racemosa

Smilax tamnifolia

Blephariglottis blephariglottis

cristata

Ibidium praecox

Sarracenia purpurea

Itea virginica

Clitoria mariana

Linum floridanum

Polygala lutea

cruciata

mariana

Ascyrum stans

Hypericum densiflorum

Rhexia mariana

Ludwigia hirtella

Oxypolis rigidior longifolia

Azalea viscosa

viscosa glauca

Kalmia angustifolia

Pieris mariana

Gaylussacia dumosa

Vaccinium corymbosum

Asclepias rubra

Agalinis setacea (Gerardia holmiana)

Utricularia subulata

Eupatorium album

album subvenosum

Laciniaria graminfolia pilosa

Solidago erecta

Aster dumosus

Doellingeria umbellata humilis

Helianthus angustifolius
Ammendale, Suitland.

Hyattsville, Reform School, Terra Cotta, Laurel.

Hyattsville, Odenton, Suitland, Riverside.

Suitland.

Riverdale.

Sarracenia Swamp, Laurel, Silver Hill.

Terra Cotta. Ábundant outside of bogs.

Reform School.

Odenton, Suitland, Laurel.

Brightwood, Suitland.

Riverdale, Hyattsville, Lanham.

Hyattsville, Bladensburg, Brightwood.

Surattsville, Hollywood.

Kenilworth, Terra Cotta.

Holmead.

In most bogs.

In most bogs.

In most bogs.

In a number of bogs; also elsewhere.

Takoma, Magnolia Run, Lanham.

In most bogs; elsewhere also.

In most bogs.

Terra Cotta, Takoma, Brookland, Lanham.

Howard Hill, Surattsville.

Hyattsville, Terra Cotta; also outside of bogs.

Terra Cotta; also outside of bogs.

Takoma, Terra Cotta, Magruder.

Terra Cotta; common elsewhere.

Reform School; also outside of bogs.

Terra Cotta.

in most bogs.

To the above may be added a list of characteristic Pine Barren Plants occurring about Washington or to the east- 


\section{ward in Maryland and Delaware, ${ }^{57}$ but not necessarily in bogs.}

Lycopodium alopecuroides

Chamecyparis thyoides

Pinus rigida

Sagittaria longirostra

Panicum meridionale

spretum

commonsianum

Amphicarpon amphicarpon

Sporobolus torreyanus

Agrostis elata

Cyperus cylindricus

dentatus

Eleocharis robbinsii

torreyana

tricostata

Scirpus subterminalis

Eriophorum tenellum

Rhynchospora torreyana
fusca
oligantha
Cladium mariscoides
Carex barrattii

Newcastle County, Del. Tatnall, Keller and Brown.

Pocomoke, Wicomico and Nanticoke Rivers, Md.

Common throughout.

Oxon Run, Prince Georges County, Md.

Numerous localities about District of Columbia, but apparently not in bogs.

College Park, Md.

Lewes and Cape Henlopen, Del.

Ellendale, Del.

Ellendale, Del. Williamson.

Brookland, D. C.; Silver Hill, Md.

Occurs about the District of Columbia but not in bogs.

Little Gunpowder River and Salisbury, Md.

Morris Pond and Milford, Del. Williamson.

Ellendale and Milford, Del. Williamson.

Caroline County, Md.

Dorchester County, Md.

Newcastle Co., Del. (Commons). Keller and Brown.

Felton, Del.

District of Columbia.

Lewes, Del.

Worcester County, Md.

Tinicum, Del. Keller and Brown (littoralis).

\footnotetext{
${ }^{57}$ Delaware is included because physiographically it is a part of the region here treated. The records for the plants listed were gleaned first of all from the National Herbarium, and from "The Plant Life of Maryland (Maryland Weather Service, Special Publication III, 1910). The records from these sources are given without further comment. When a local record of a plant was available search was carried no further; Maryland occurrences were next looked up, and finally Delaware reports on yet additional species were incorporated in the list. The authorities for Delaware records not obtained from the National Herbarium are indicated by surnames, the references in full being:

Keller, Ida A. and Brown, Stewardson. Handbook of the Flora of Philadelphia and Vicinity, 1905, viii, $360 \mathrm{pp}$.

Tatnall, Edward. Catalogue of the Phaenogamous and Filicoid Plants of Newcastle County, Delaware. Wilmington, Institute, 1860, $112 \mathrm{pp}$.

Williamson, C. S., Notes on the Flora of Central and Southern Delaware, Torreya, 9, No. 8, Aug., 1909, pp. 160-166.
} 
Carex walteriana. exilis

Orontium aquaticum

Xyris fimbriata

Eriocaulon septangulare

Abama americana

Smilax laurifolia walteri

Gyrotheca tinctoria

Gymnadeniopsis integra

Pogonia divaricata

Ibidium vernale

Betula populifolia

Quercus marilandica ilicifolia

Brasenia purpurea

Meibomia stricta

Lespedeza angustifolia

Hypericum virgatum ovalifolium

Tithymalopsis ipecacuanhae

Ilex glabra

Lechea minor racemulosa

Rhexia aristosa

Ludwigia linearis

Proserpinaca pectinata

Myriophyllum humile

Chamaedaphne calyculata

Oxycoccus macrocarpus

Trichostema lineare

Schwalbea americana
Ellendale, Del.

Millsboro, Del.

Common about District, but as a rule not in bogs.

Wicomico River, Md.

Occurs about District, but not in bogs.

Newcastle County, Del. Keller and Brown.

Salisbury, Md.

Salisbury, Md., and Patapsco River, Md.

Georgetown, Del. Williamson.

Felton, Del.

Ellendale, Del. Williamson.

Present in the District of Columbia region, but not in bogs.

New Castle County, Del. Tatnall.

Abundant.

Laytonsville and Goshen, Montgomery County, Md.; Odenton, Md.

Occurs about the District of Columbia, but not in bogs.

Ocean City, Md.

Wicomico County and Ocean City, Md.

Ellendale, Del.

Common.

Surattsville, Prince Georges County, Md.

Occurs about the District of Columbia.

Plentiful about the District of Columbia.

Ellendale, Del. Williamson.

Worcester County, Md.

Chesapeake Beach, Md.

Occurs according to "Plant Life of Maryland."

Furnace Creek and Glenburnie, Md. ${ }^{53}$

Newcastle County, Del. Keller and Brown.

Newcastle County, Del. Keller and Brown.

Newcastle County, Del. Keller and Brown.

${ }^{35}$ For a summary of the vegetation of the Glenburnie bog, see Science, 22 , p. 15 , July 7,1905 . 


\section{Utricularia cornuta cleistogama inflata purpurea \\ clandestina fibrosa \\ Galium pilosum puncticulosum \\ Lobelia nuttallii canbyi}

Sclerolepis uniflora Eupatorium leucolepis Solidago stricta

puberula

fistulosa

Aster spectabilis

Bidens trichosperma tenuiloba

Nabalus virgatus
Anne Arundel County, Md.

Georgetown, Del. Williamson.

Dorchester County, Md.

Morris Pond and Ellendale, Del. Williamson.

Harford County, Md.

Anne Arundel County, Md.

Wicomico County and Leon, Md.

Worcester County, Md.

Ellendale and Georgetown, Del. Williamson.

Wicomico County, Md.

Ellendale, Del.

Occurs according to "Plant Life of Maryland."

Occurs about Washington, D. C.

Ocean City, Md.

Wicomico County, Md.

Worcester County, Bush River, Choptank River, Md.

Ellendale, Del.; Sussex County, Del.

The 53 species ${ }^{59}$ of plants found in Magnolia bogs in the vicinity of the District of Columbia added to the 71 occurring elsewhere in the Coastal Plain region to the eastward ${ }^{60}$ that are identical with species listed by Stone as characteristic of the Pine Barren flora of New Jersey make up 70.5 per cent ${ }^{61}$ of that list (total, 173).

\footnotetext{
${ }^{59}$ Polygala lutea, Polygala cruciata, Rhexia mariana, and Xyris caroliniana are species recorded by Brereton, but included in the list of plants not found by Ward (Flora pp. 12-13), which have since been collected in Magnolia bogs. May we not also hope to discover in these bogs other plants mentioned, and with little doubt seen, by the older writers such as Chamaedaphne calyculata, Trichostema lineare, Arethusa bulbosa and Pogonia divaricata?

${ }^{60}$ A number of other characteristic species are found in eastern Virginia. Three occurring in the Norfolk-Virginia Beach area may be mentioned: Nymphaea americana (variegata), Hudsonia ericoides and Aster gracilis.

o1 This fact undermines considerable speculation based on the supposed absence of Pine Barren plants from Maryland and Delaware. For instance the following from Harshberger (Dr. J. W., The Vegetation of the New Jersey Pine Barrens, 1916, p. 2): "This isolated island of pine-barren plants was removed still further from contact with the Southern pine-barrens by the unequal depression of the coastal plain, so that with the exception of the island vegetation, the typic coastal plain plants were exterminated in the depressed portion of the plain in Delaware and Maryland * * * for Shreve has indicated the almost utter lack of pinebarren plants in Maryland."
} 
Seven-tenths of the distinctive Pine Barren plants, therefore, occur in eastern Maryland and Delaware, yet there are no Pine Barrens. What is the reason? In considering this point it may be helpful to give a brief picture of the New Jersey Barrens. The soil is sand, one is tempted to say pure sand, loose and shifting where dry, and compact where wet. Gravel occurs in varying degrees being most abundant on the area known as the Plains, where the regetation is depauperate and farorable conditions for plant growth evidently at the minimum. Poor soils rule, therefore, and with the poorest is associated the climax of vegetational features that have won for these areas the name "barrens."

Briefly noting the regetation beginning with the largest growths, Pinus rigida is the only species, attaining tree stature in the dre parts of the typical Pine Barrens. Chamaecyparis almost as exclusively occupies a corresponding position in the well-watered places where it is the most important element of the cedar swamps. Over the ordinary surface of the Barrens, however, Pinus rigida reigns supreme. Next to it in stature are four oaks: Quercus marilandica, $Q$. stellata, $Q$. prinoides and $Q$. ilicifolia.

A conspicuous characteristic of the undergrowth is the tendency of the species to occur in colonies. In the drier parts, here Arctostaphylos uva-ursi mats the surface, there Dendrium buxifolium monopolizes a space, or it may be Hudsonia ericoides, Gaultheria procumbens, Kalmia angustifolia or Gaylussacia or Vaccinium. In wet places Chamaedaphne calyculata, alder, clammy azalea, and Rhus vernix are conspicuous. The actual floor of the Barrens in dry sandy areas abounds with Cladonia and in the wet spots with sphagnum and Sarracenia. On wet bare sand grow the characteristic species of Lycopodium and that greatest treasure of the Pine Barrens-the little curly fern, Schizaea pusilla.

Obviously the predominant elements of the Pine Barren flora are plants that either prefer the so-called poor (presumably acid) soils, or that find sanctuary in soils in which competition with the plants of neighboring areas is greatly 
reduced or eliminated. Applying these facts to the situation in Maryland and Delaware, and bearing in mind that 70.5 per cent of the characteristic pine barren plants are known to occur, it would seem that the chief reason for the lack of true Pine Barrens is that large tracts of the soils which Pine Barren plants are able to monopolize are wanting. ${ }^{62}$

The fact that some of the very elect 63 of the Pine Barren flora occur here and there tucked away in bogs, where they are protected from competition with the ordinary vegetation of the district, shows that our region had its chance for Pine Barrens in that there certainly was a movement of the Pine Parren flora over the area.

This idea is further supported by the character of the fossil flora of the region which includes such Coastal Plain 1ypes as Osmunda, Taxodium, Myrica, Planera and Andromeda. Even Dendrium, one species of which now is a characteristic Pine Barren plant, has been found. (See especially papers by Dr. E. IT. Berry, Bulletin Torrey Botanical Club, 33, 1906, pp. 103-182; 37, 1910, pp. 19-29, and Americau Naturalist, 43, 1909, pp. 432-436.)

Leaving in abeyance the question of absolute origin of the Pine Barren flora, it may be stated that general agreement is to the effect that at one time there was a great body of this flora along much, possibly most of the Atlantic Coast. Then came one or more of the later subsidences to which the Coastal Plain has been subjected. These were exceedingly slow, of course, and there was ample time for plants to shift their stations in response to the ever encroaching coast line.

\footnotetext{
${ }^{62}$ In this connection consider R. M. Harper's conclusions: "The most satisfactory system of geographical classification of the vegetation of temperate Eastern North America is one based on geology," and "The coastal plain, which is defined on strictly geological grounds, is probably the most distinct natural subdivision of temperate Eastern North America, differing notably from all other subdivisions in soil, topography, and geological history, and to a corresponding extent in its flora." (A Phytogeographical Sketch of the Altamaha Grit Region of the Coastal Plain of Georgia, Ann. N. Y. Ac. Sci. 17, Part I, 1906, p. 342). Also Witmer Stone's remark: "I feartily agree with Dr. Hollick's contention that 'the mechanical structure of the soil' is the most potent factor in the distribution of plants" (Plants of Southern New Jersey, p. 81).

¿ Lycopodium carolinianum, Tofieldia racemosa, Abama americanc, Polygala lutea, Ludwigia hirtella, and others.
} 
The struggle for place must have been intense, however, for conditions on the Piedmont were unfavorable. Probably in many cases a strip back of the beach was the only suitable habitat for the Pine Barren plants. During the last retrograde morement, howerer, these plants must have found numerous farorable habitats, and where these have not been destroyed by drainage, by covering with other deposits, or by operations of man, the plants remain to this day. What happened may be compared to the movement of plants during the glacial periods. Their response to the progress of the ice is undoubted, and during the retreat of the glaciers bodies of northern plants were stranded here and there and have persisted usually on mountain tops where the conditions are most like those to which they were acclimated and where competition consequently was least severe.

So with the Pine Barren plants. The movement of this flora toward, if not onto, the eastern part of the Piedmont Plateau, when the latter was depressed, and their retreat (before competing species) when it was again elevated must be compared to the flow and ebb of the tide, which leaves merely a bit of foam at one point, a little pool at another, but, where conditions favor, a whole lagoon. What may be thought of as persistent spume from this vegetational tide are the few colonies of Pine Barren plants lodged in the Appalachian Mountains. ${ }^{64}$ Our Magnolia bogs represent the

\footnotetext{
a See especially Kearney T, H. "The lower austral element in the flora of the southern Appalachian region. A preliminary note." (Science, N. S. 12 , pp. $830-842$, Nov. 30,1900$)$, and The Pine-Barren Flora in the East Tennessee Mountains. (Plant World, 1, No. 3, Dec., 1897, pp. 33-35). In the latter paper the following typical pine barren plants are mentioned: Eupatorium album, Ascyrum stans, Juncus aristulatus, Pogonia divaricata, and Itea virginica. The suggestion is made that "probably, * * * they are the lingering survivors of a more southern flora, once widely distributed over the southern Apalachian region." (p. 35.) This theory is approved by Norman Taylor (Flora of the Vicinity of New York, 1915, pp. 25-26. The relict theory may be entertained, if we assume that the whole region over which Pine Barren plants are now found was once occupied by the Pine Barren flora, but that this has since been crowded by an aggressive new flora out of all but the most favorable areas. But necessary premises for this conception do not seem probable, since it is doubtful whether the largely non-autophytic Pine Barren flora, which now seems to have such strict limitations as to soil and other edaphic conditions, ever was predominant in the soils resulting from simple disintegration of the metamorphic rocks. At any rate the relict hypothesis will not explain the presence of Pine Barren plants in our Magnolia Bogs and
} 
tide pools, while such areas as the Pine Barrens of New Jersey and Georgia are vast lagoons, and as it happens, the chief reservoirs of a tide that is not yet wholly still, and which may in future undergo movements similar to those we must believe have occurred in the past.

In conclusion, therefore, it seems clear that the Magnolia Bogs of the vicinity of Washington harbor the survivors of one or more of the plant waves ${ }^{65}$ that accompanied each depression of the Atlantic Coast Region. The antiquity of some of these little waifs and the vicissitudes they have survived entitles them to our respect, while the slender thread upon which their continued existence depends commends them to our most considerate care.

While the Magnolia bogs contain a large number of characteristic Pine Barren plants, and the District of Columbia, eastern Maryland, and Delaware together can boast representatives of seven-tenths of the typical Pine Barren species, there are no Pine Barrens in the region. The reason appears to be absence of considerable areas of the necessary surface deposits to permit extensive colonization of Pine Barren plants and to protect them from competition with other types of vegetation.

\section{O'THER TYPES OF COLLECTING GROUNDS IN THE DISTRICT OF COLUMBIA REGION.}

The writer neither expects to replace, nor hopes to equal in interest the delightful accounts of local collecting places that

similar spots in the Coastal Plain which have been entirely and repeatedly submerged. That they have been left in these places by a tidal movement of the Pine Barren Flora, as above outlined, is the irresistable conclusion. Probably the occurrence of numerous pairs of closely related species in the Coastal Plain and Southern Appalachians may be taken as evidence of a similar movement, and further as proof of a lapse of time since the last commingling of the floras sufficient for the development of the divergences now shown. It seems more natural to regard the Coastal Plain rather than the region of Archean rocks as the ancestral home of a flora which shows such pronounced dependence upon silicious soils. R. M. Harper, especially, points out the probable recent origin of the Coastal Plain flora (Ann. N. Y. Ac. Sci. 17, Pt. 1, 1906, pp. 11-13).

${ }_{65}$ This tidal movement of plants occurred along our whole Atlantic Coast, and evidences of it as far North as Labrador, together with an interesting discussion of the matter have been published by Professor $\boldsymbol{N}$. L. Fernald. (Rhodora, 13, July, 1911, pp. 135-162.) 
may be found in the writings of Ward ${ }^{66}$ and Coues. ${ }^{66}$ Approaching the subject from a somewhat different point of view, only brief descriptions of localities will be given, but an effort will be made to point out distinctive features of various areas, and especially to name the peculiar or at least characteristic species that have been collected in each.

In the last chapter, where the Magnolia bogs were treated in detail, the prevalence of sandy soils in the Coastal Plain was mentioned. This characteristic is especially noticeable at what have proved to be the most interesting collecting places in the Coastal Plain, one of which is Beltsville. The Powdermill Bogs, as stated in the foregoing chapter, are located about two miles west of Beltsville. They do not monopolize the interesting features of this region, however, as the country in all directions about them has proved to be good collecting ground. Among insects bee-flies (Bombyliidae) and robber-flies (Asilidae) are especially numerous both in individuals and in species. Here only in the Washington region have been captured Lepidophora, Systoechus, and Metacosmus of the former family, and only here and near Berwyn an undescribed species of Rhabdoselaphus of the same family. Of the Asilidae, Asilus johnsoni and Dasyllis champlaini have been collected only at Beltsville, and of Tabanidae or horseflies, Tabanus astutus and T. superjumentarius have been obtained only here and $T$. recedens and Chrysops cuclux here and in the Eastern Branch country toward Berwyn. Three species of Syrphidae: Microdon craigheadi, Eristalis saxorum and Xylota facialis, also have only been taken in the Powdermill vicinity. The bogs are an especially good place to find the Dascyllid beetle, Odontonyx trivittis. Interesting species of Elater are attracted

\footnotetext{
Flora, 1881, pp. 17-26. Avifauna, 1883, pp. 11-27. Less comprehensive, but nevertheless interesting matter bearing upon this subject was published by Dr. E. L. Greene, in Cybele Columbiana, 1, No. 1, Dec., 1914, pp. 11-14. Dr. Greene's remarks apply' chiefly to the Upper Potomac Valley. The "localities of special interest to the botanist" of Ward include the Rock Creek Region; the Upper Potomac Region; the Lower Potomac Region; the Terra Cotta Region; the Reform School Region; the Holmead Swamp Region, and the Eastern Branch Region. Coues treats the Potomac River Region (High Island to Alexandria), the Eastern Branch Region (Bladensburg to Giesboro) and the Pock Creek Region.
} 
to the flowers of Clethra, the Amelanchier bushes produce Saperda candida and S. tridentata, and Sassafras in this neighborhood seems to harbor an unusual number of Oberea ocellata and 0 . ruficollis. Chinquapin bushes are common and to their flowers come a horde of longicorns of the genera, Leptura, Strangalia, and others; Balaninus of a number of species; and once in great abundance Amphicoma ursina. The Beltsville vicinage has many large ant colonies and ant guests are more than ordinarily common. Species of Microdon have been mentioned, and among others several species of Cremastochilus also have been collected, including the rather scarce $C$. linochii.

In connection with Hemiptera, Beltsville is of interest as the type locality of the strikingly colored Reduviid Pselliopus barberi, and of certain varieties of species of the Mirid genus Paracalocoris. Tree hoppers inhabiting chestnut and hickory are especially common.

Odenton, Md., is another sandy locality of considerable interest to collectors. Near the station, and somewhat cut up by railway embankments is one of the best developed Magnolia bogs of the region. In late summer Polygala lutea and the white-fringed orchid here makes a gorgeous show. Scrub or bear oak (Quercus ilicifolia) is common at Odenton, and indications are that the locality will repay search for other Pine Barren plants. The country near Odenton has proved to be a particularly good place for collecting Hemiptera, especially Miridae. It has vielded some very desirable beetles also, among which are Cremastochilus leucostictus and the austral Meloid. Tetramy quadrimaculata.

Laurel, Md., on the Patuxent River, is one of the localities from which both Piedmont and Coastal Plain conditions are easily accessible. The gorge of the river above the town is very interesting and has been found a good collecting locality. Three young men will long remember a Decoration Day spent there, when Yellow-bellied Flycatchers were common, and two Mourning Warblers and a Philadelphia Vireo were collected. The Patuxent River is bordered by extensive swamps below Laurel, and hidden in these are bogs which still yield pitcher plants (Sarracenia purpurea), white- 
fringed orchids, and Polygala lutea. A list showing the great variety of trees occurring in the vicinity of Laurel has been published by Robert Ridgway. ${ }^{67}$

A little toward Washington from Laurel are Contee, Muirkirk and Ammendale, all profitable spots for botanical exploration. The first-named also has been quite productive of both plant and animal fossils.

Passing the Beltsville vicinage which has already been described, it may be noted that at Hollywood there is a boggy swamp, notable for Dryopteris simulata, and an extensive colony of Unifolium canadense. Branchville is adjacent to a large wooded swamp which harbors various hawks and a larger than usual number of small mammals.

Riverdale and Hyattsville are notable chiefly for their Magnolia Bogs, the character of which has previously been discussed. The former locality is noted for best stocked climbing fern locality and the latter for colonies of Iris verna and of Parthenium integrifolium. Excavating operations in the Hyattsville bog have resulted in its having more and deeper water than the remainder of these bogs. This favors the development of aquatic insects, among which Pelocoris and Notonecta uhleri are rarely collected elsewhere.

Bladensburg is an old place, with many historical associations, and its environs offer good collecting. Formerly it was a favorite resort for collectors. It is an especially good place for the small vernal beeflies (Bombylius pygmaeus and $B$. pulchellus) and for the interesting autumnal robber fly (Vicoles politus). Such good, although not rare, bugs as the Nabid (Carthasis decoratus) and the Mirid (Cylapus tenuicornis) have more than once been collected at this point.

Somewhat farther down the Eastern Branch, below the Pennsylvania Railroad, is Licking Banks, the hill behind which is one of the "high spots" most frequented in spring by migrating birds. An exposure of an indurated sandy deposit at the foot of the hill furnishes nesting sites for

en Proc. U. S. Nat. Mus. 17, 1894, p. 417. 
kingfishers, swallows and burrowing bees. Among the latter once flourished a colony of Anthophora from whose nests were obtained specimens of the rare Meloid, Hornia minutipennis.

In illustration of the marshy portions of the Eastern Branch, the section in the bend opposite Benning will be discussed. The abundance of wild rice here, the bird hosts that feed upon it, and the sport dependent upon their presence, need not be commented upon, for they have been fully described by Coues. Among the characteristic or peculiar plants of this part of the marsh are Scirpus fluviatilis and S. sylvaticus, Eleocharis quadrangulata, Carex riparia, Lophotocarpos calycinus, Ranunculus ambiguus, Cabomba caroliniana, Lathyrus palustris, Itea virginica, and Eryngium virginianum.

Upon this vegetation may be found such insects as the aquatic leaf beetles (Donacia), soldier flies (Stratiomyidae), and the hymenoptera that visit the flowers of pickerel weed (Pontederia cordata) and of Eryngium. Rare beetles that have been collected in this locality include the Carabidae, Ardistomis obliquata, Cymindis elegans and Casnonia ludoviciana, the Staphylinid, Thinobius fimbriatus and the Anthicid, Mecynotursus cundidus. The Casnonia, along with Leptotrachelus dorsalis, another uncommon Carabid, are most easily obtained by sifting debris at the edge of the marsh in winter. A few spots along M Street extended have proved best for the search. With these beetles are brought to light numerous Stenus, Pselaphidae and Donacia. Aquatic bugs as Limnobates, Hebrus, and Velia stagnalis also are disclosed. This locality and this method are by far the best for collecting the last-named species, which is among the desiderata of most bug collections.

Fishes that are most abundant in the Eastern Branch and similar well vegetated waters include the gar (Lepisosteus osseus), mud minnow (Umbra pygmaca), pickerels (Lucius americanus and $L$. reticulatus), killifishes (Fundulus diaphamus and $F$. heteroclitus), the silverside (Menidia beryllina) and the sunfishes (Enneacanthus gloriosus and $E$. obesus). 
The densely vegetated waters that harbor these fishes are confined to the shallower parts of the main river, and its tributaries from the head of Little River at Analostan Island, downstream. Within the limits of the District fauna and flora, these waters constitute a vegetational unit, characterized by the abundance of submerged aquatics, as wild celery (Vallisneria spiralis), waterweed (Philotria canadensis), and various pondweeds as Naias flexilis, Zannichellia palustris, Potamogeton crispus, P. pectinatus, $P$. pusillus, $P$. perfoliatus. $P$. compressus, $P$. amplifolius, and $P$. robbinsii. Most of these species are restricted to Coastal Plain waters, except as they have obtained a foothold in the canal. The marshes bordering such waters have as their principal elements wild rice, cattails, bulrushes, cord-grass, pickerel weed, spatterdock, Peltandra and Sagittaria.

Four collecting areas on the Virginia side which share more or less the regetation above described are Four-mile Run, Hunting Creek, Dyke and Mount Vernon. Wherever there is rank marsh along this stretch of shore, occur the cowbell frog or tink-tank (Hyla evittata) and the least bittern (Ixobrychis exilis). Both species go upstream as far as the Little River Marsh. A plant that has about the same range is Isoetes saccharata.

Four-mile Run has a distinct tidal marsh near the mouth in which all three of these species occur. The low ground about the mouth of the creek and the bordering hills are interesting collecting grounds. Various southern craneflies have been collected here and St. Elmo in this area is the type locality for a remarkable robber fly (Asilus angustipennis ${ }^{68}$ ) and the sole station in our area for a striking southern species of the same family, namely, Laphria saffrana. Plants that have been collected here only are Panicum flexile and Paspalum longipedunculatum.

The old city of Alexandria, a little farther down stream, is principally distinguished, from a naturalists point of view, by harboring various introduced species that have not become established elsewhere. These include Salsola kali, Atriplex hastata, Heliotropium europaeum, Hibiscus syriacus

es This has been taken at Beltsville also. 
and Artemisia caudata. An insect having the same history is the Tenebrionid beetle, Blaps similis.

Hunting Creek, just below Alexandria, has a very interesting flora. It is filled with aquatic vegetation, among which Potamogeton robbinsi and Utricularia macrorhiza are its exclusive possessions in this vicinity. The peculiar marsh plants are Eleocharis flaccida, Carex gracillima, Plantago cordata (also found opposite Alexandria) and Eupatorium cannabinum; and mud plants, Isoetes riparia and Micranthemum micranthemoides. Other interesting species occurring here are Alopecurus geniculatus, Pedicularis lanceolata and Galium asprellum.

The large marsh and abruptly rising hills at Dyke, a little farther down stream, furnish good collecting in various lines. The marsh is a beautiful sight during the flowering season of the abundant introduced lris pseudacorus. In this marsh only has been collected the fragrant ladies tresses (Ibidium odoratum). Dyke has produced several additions to the list of crane-flies of the region, and has yielded the only specimen so far obtained of the remarkable horsefly, Merycomvia. The large hymenopteron, Pepsis elegans, related to the wester'n tarantula hawks, has been seen only at Dyke and Mount Vernon. These two localities also are the only known breeding stations in our area for the yellowthroated warbler (Dendroica dominica). Practically all specimens of the Prothonotary Warbler (Protonotaria citrea) seen or collected in this vicinity have occurred at Dyke.

Mount Vernon is strongly and fittingly distinguished as a breeding site of the Bald Eagle-our national bird thus making its home on the estate where lived the father of our country. Ospreys are usually to be seen over the river at Mount Vernon and in winter, the river from this point downstream is frequented by large flocks of various species of wild ducks. Noteworthy plants found at Mount Vernon are Spigelia marilandica and Inula helenium. Mount Vernon has yielded a number of the pretty little Scarabaeid, Trichius delta, and the only specimens so far obtained of the 
southern robber fly Evax nemoralis. With Marshall Hall is shared the little lace bug, Leptoypha costata.

At Marshall Hall have been found such austral plants as bald cypress (also at Bowie), Polypremum procumbens ${ }^{69}$ and Pluchea camphorata, and rather surprisingly such highland ferns as Athyrium pycnocarpon. Cystopteris fragilis, and Camptosorus, and Trautretteria which are more characteristic of Piedmont areas. A paper based on investigations at Marshall Hall, and which altogether gives a rather full discussion of the local fauna and flora, is Dr. S. D. Judd's "Birds of a Maryland Farm, A Local Study of Economic Ornithology" (Bul. No. 17, U. S. Biological Survey, 1902, 116 pp., 17 Pls., 41 Figs.).

One of the most interesting downstream localities is Occoquan, Va., and perhaps the chief reason for its attractiveness is the excellent opportunity for study of the line of contact of the Piedmont and Coastal Plain formations and their accompanying biotas. The old village of Occoquan is one of the numerous settlements that were made on the Fall Line, and in this case the natural advantages of a good bridge site, power from rapids, and deep water for shipping are admirably concentrated.

With regard to geological conditions at Occoquan, Fontaine $^{70}$ says: "In the top of the hill overlooking the river and in the village a thin remnant of the Potomac [a Coastal Plain formation] may be seen. It is composed of gray, argillaceous sand, variegated with yellowish-brown and reddish colors. In this vicinity the Potomac has been almost wholly removed by erosion and is visible only on the highest points. The depth to which the depressions have been cut since the deposition of this formation indicates for it a great age. In the immediate vicinity of the village of Occoquan the thickness of fully 200 feet of pre-Cambrian rock is exposed under the Potomac, being laid bare by erosion in the post-Potomac times. These pre-Cambrian rocks are no longer wholly slates, but in the lower portions rather coarsegrained and highly crystalline mica-schist and highly mica-

Has been collected at Benning also.

${ }^{70}$ Fontaine, W. M. The Potomac Formation in Virginia. Bul. 145, U. S. Geol. Survey, 1896, pp. 113-4. 
ceous gneiss may be seen. On the north side of the Occoquan River, opposite the village of Occoquan, the high hills that overlook the river seem to be composed wholly of micaschist.

"From the village of Occoquan due east down the river to Woodbridge, where the railroad crosses the river, the distance is 2 miles (p. 113). The station is on the opposite side of the river from the site of the former village of Colchester, where the Colchester road crosses the river. At Woodbridge the railroad approaches the bridge by a long cut. In this cut the Potomac formation may be seen resting on pre-Cambrian slate similar to that which, at Dumfries and northward, forms its western boundary. The bottom of the Potomac formation is here about 40 feet above the river. The formation, in the interval of 2 miles between this station and the village of Occoquan, has declined toward the east certainly as much as 160 feet" (p. 114).

Growing among the Piedmont rocks immediately above Occoquan village is the most extensive colony of Rhododendron maximum known in our region. Some of the northern exposures of the main ravine and its tributaries have patches of the plant covering acres. Wintergreen is abundant near Occoquan and the Pyrola, Lycopodium and even white pine that characterize our most marked Piedmont woods have been found. Hemlock is especially common, probably more of it growing here than in all other places together within the same distance of Washington. It follows the Piedmont rocks to their very limit, and due to the character of the exposure (as described above) it comes about that hemlocks can be found with their roots bathed by the waters of a tidal marsh. This is a remarkable occurrence for our latitude.

Occoquan is further of interest as a station for the hairy fern, Cheilanthes lanosa, for the occurrence of Filago germanica, and for the persistence in its environs of the wild turkey.

Returning to localities nearer Washington some account will be given of Glencarlyn and Falls Church of the Rock Creek Region, Takoma Park, and finally of the chief spots of interest along the upper Potomac. 
Four-mile Run Valley, for its whole course, provides interesting and profitable collecting grounds, none of which, however, excels the vicinity of Glencarlyn. The bottom land along the creek near the Carlin Springs has a wonderful insect fauna, an indication that the locality will repay investigation in other lines. Some things that have been collected only at Glencarlyn are the flower fly (Syrphus fisheri), the lampyrid beetle Neoceletes crateracollis described as a new genus and species, and the scorpion flies Bittacus pilicornis, B. stigmaterus, and B. punctifer.

Certain restricted areas near Falls Church seem to share with Glencarlyn some of the most remarkable species, according to notes kindly furnished by Mr. Nathan Banks. The very rare Syrphid fly, Mixogaster breviventris has been taken only at these two points in our area; the same is true of the Leptid fly Rachicerus fulvicollis and the scorpion fly Panorpa virginica.

Falls Church is not without its own peculiar forms as only here have the following rare Syrphid flies been taken: Callicera johnsoni, Xanthogramma felix, Criorhina verbosa, Volucella obesa and Ceria abbreviata; the remarkable hemerobiid Dilar americana described from a single specimen was rediscovered at Falls Church; and the only specimens from this region of the pretty little Psyllid Livia marginalis were obtained at Falls Church. Interesting hymenoptera of southern affinities which have been collected here include the mutillids: Ephuta pauxilla, Mutilla ornatipennis, Pseudomethoca geryon, Sphaerophthalma johnsoni, S. rubroscutellata, and Photopsis myrmicoides; the Psammocharidae; Priocnemus facetus, and Ageniella accepta and the Sphecid genus Podium.

Many records and descriptions of new species of insects from Falls Church have been published by Mr. Nathan Banks to whose collecting acumen most of the above records is due. ${ }^{71}$ Mr. Banks has left the scene of his fruitful endeavors,

\footnotetext{
71 Another instance of the importance of the collector is afforded by the records (unique in the region) of the following orthoptera at Vinson Station, Va.: Hesperotettix brevipennis, Anurogryllus muticus and Oecanthus pini. All of these were captured by $\mathrm{H}$. A. Allard who has unusual ability to detect orthoptera by their stridulations.
} 
but a field station of the Division of Forest Insects is located at Falls Church, and a number of entomologists live there, so that we may hope to see the interesting insect fauna of its environs further exploited. Only a single species of plant seems to have its sole local station at Falls Church, namely, Sabbatia campanulata.

The Rock Creek region was explored more thoroughly by the preceding generation of naturaiists than by those of today and good accounts of it are given by Coues and Ward. It is mentioned here chiefly to call attention to the interesting flora of Woodley Park. This area was diligently scanned by Ward, Dr. E. S. Burgess and others and produced a number of plants not found elsewhere. It was long the sole locality for Solidago rigida, which has since been detected at Cabin John. At Woodley exclusively the following have been found: Phlox pılosa, Monarda mollis, Helianthemum canadense, Aster concinnus, and Cirsium odoratum.

For the remainder of the Rock Creek region, the accounts of Ward and Cones should be consulted. It is worth while to repeat perhaps that Rock Creek has a good colony of our most peculiar pine, Pinus pungens and that only one station beside this region has been found for the orchid Triphora trianthophora and for Polemonium reptans. It should be mentioned also that Rock Creek Park furnishes one of the lowermost stations for the Piedmont Iris cristata, and that the following plants, besides those named by Ward, have. been collected solely in this area: Meibomia pauciflora, $M$. grandiflora, Diervilla diervilla and Aster tradescanti.

It may be added that where Kalmia street crosses Fenwick Branch there is a fine colony of Monarda punctata, which in flower attracts numerous interesting insects. Among the best species collected here are the flower-loving beetle (Rhipiphorus pectinatus), the bee (Calliopsis tricolor) and the sphecid wasp (Proterosphex nudum). The whole assemblage has Coastal Plain affinities and is here on the fringe of its domain.

Piney Branch, a tributary of lower Rock Creek, has been 
a most interesting locality for naturalists, but is nearly ruined now. Draining into it was Holmead Swamp, which was one of the most interesting of the Magnolia Bogs, and one most thoroughly explored. On the north side of Piney Branch near its mouth are remains of the most extensive implement workshop of the Indians that has been found in this locality. At the head of Soapstone Creek, a tributary higher up and on the other side of Rock Creek, is an ancient quarry where the aborigines made soapstone vessels and other articles.

Takoma Park is notable chiefly as an illustration of the strength in which the Coastal Plain flora holds positions in the rery margin of the Coastal Plain deposits. The region is in a peninsulated part of these formations, yet it had a typical Magnolia bog (now obliterated) and in this and elsewhere in the neighborhood the following typical Coastal Plain plants among others have been collected: Panicum microcarpon, $P$. columbianum thinium, $P$. aculeatum, Xyris flexuosa, Eriocaulon decangulare, Sisyrinchium atlanticum, Blephariglottis ciliaris, Rhexil virginica, Kalmia angustifolit and Viburnum nudum. The farthest point reached in this area by any of these species is on Sligo Creek about 2 miles north of Takoma.

\section{THE UPPER POTOMAC REGION.}

In this division may be included the river valley and adjoining bluffs from Aqueduct Bridge to the limit of the Washington area. This area includes some subdivisions worthy of special notice, as the vicinity of Great Falls, the flats in the neighborhood of and below Chain Bridge, and some of the islands. These will receive separate mention.

Along most of this part of the river the bottomland is narrow, especially so on the Virginia side. The bluffs rise rapidly to the elevation of 250 feet in the lower part of the region, and to from 350 to 400 feet in the northwestern part. Small streams, abruptly descending near the river, and springs are abundant. Most of the area is well wooded, the 
cultivated land usually being separated from the river by a belt of forest.

The general fauna and flora of the Upper Potomac hills undoubtedly is shared by the Piedmont Plateau for an indefinite distance in each direction away from the river. Apparently the variety of animals and plants really is less, back from the river, although it must be admitted that such areas have been much less thoroughly explored.

Be that as it may, it is highly evident that the Potomac, like most rivers, forms a highway for animals and plants, along which movements are much more obvious than elsewhere. The Virginia Bluff, because of its practical continuity with the mountainous region upstream and its cool slopes, harbors a fauna and flora, related in many ways to that of the mountains. Illustrative of this fact is the occurrence of such plants as white pine, Table Mountain pine, hemlock, sweet birch, and rhododendron; such mammals as the wood rat and Microsorex; and such beetles as Cychrus andreusii. C. viduus, C. unicolor, Ptomophagus ulkei, Plectrodera scalator and Boros unicolor.

The Maryland shore of the Potomac, being in direct physical connection with the large Coastal Plain element of our fauna and flora, and having more warm exposures, is more apt to yield organisms of southern affinities. Thus the sweet gum, spanish oak, willow oak, and trumpet creeper ascend the river much farther on the Maryland than on the Virginia shore. The same is true of such bugs as Echtrichodia cruciata, Oncocephalus, Stenopoda, Ploariodes, Banasa euchlora and Cosmopepla carnifex. Thus it seems that for northern forms the south side of the river is most favorable, and for southern forms the north side.

The role of the river as a biologic highway is perhaps most evident from the flora of the islands and floodplains. There is a distinct tendency for Piedmont plants to reach their farthest downstream points on islands, for instance, Quercus muhlenbergii and Arisaema dracontium, on Analostan Id., and Cacalia reniformis and Silene nivea, on Alexanders Id. It should be mentioned here that one of our plants appar- 
ently inhabits only rocky floodplains, that being Baptisia australis, which has been collected at Williamsport, Great, Stubblefield and Little Falls.

The floodplain of the Potomac at the latter locality yields a very thorough and interesting mixture of lowland and highland forms. Ward (Flora, pp. 21-22) has commented upon the diversity of conditions and richness of the flora of the Chain Bridge Flats, but has not forestalled the usefulness of a tabulation of the most interesting plants and their relation to the Coastal Plain and Piedmont floras.

\section{CHARACTERISTIC PLANTS OF THE CHAIN BRIDGE FLATS, WITH NOTES ON THE DISTRIBUTIONAL RELATION- SHIPS OF SOME OF THEM.}

\begin{tabular}{|c|c|}
\hline Echinodorus radicans & Polygonum amphibium \\
\hline Coastal ${ }^{\tau 2}$ & Paronychia dichotoma \\
\hline Sagittaria rigida & Piedmont \\
\hline Andropogon furcatus & Brasenia schreberi \\
\hline Paspalum laeve & Radicula sessiliflora \\
\hline Coastal & Coastal \\
\hline $\begin{array}{l}\text { Panicum laxiflorum } \\
\text { Coastal }\end{array}$ & $\begin{array}{l}\text { Meibomia marylandica } \\
\text { obtusa }\end{array}$ \\
\hline Eragrostis hypnoides & $\begin{array}{l}\text { obtusa } \\
\text { Lathyrus venosus }\end{array}$ \\
\hline frankii & Piedmont \\
\hline Piedmont & Ceanothus ovatus \\
\hline Scirpus debilis & Piedmont \\
\hline Eleocharis palustris glaucescens & Vitis rupestris \\
\hline Carex comosa & Piedmont \\
\hline lupulina & Elatine americana \\
\hline hystricina & Piedmont \\
\hline Piedmont & Ammania Koehnei \\
\hline Allium cernum & Coastal \\
\hline Piedmont & Lythrum alatum \\
\hline Vagnera stellata & Decodon verticillatus \\
\hline Piedmont & Kneiffia linearis \\
\hline Ibidium plantagineum & Coastal \\
\hline Piedmont & Samolus floribundus \\
\hline Salix interior & Steironema quadriflorum \\
\hline Piedmont & Piedmont \\
\hline wardi & Hydrophyllum canadense \\
\hline cordata & Piedmont \\
\hline Piedmont & Phacelia covillei \\
\hline Quercus prinoides & Piedmont \\
\hline
\end{tabular}

i2 Such notation applies only to one (the immediately preceding) species. 
Isanthus brachiatus

Piedmont

Koellia mutica

Coastal

Mecardonia acuminata

Coastal

Utricularia gibba

Valerianella chenopodifolia Piedmont woodsiana

Piedmont
Eupatorium hyssopifólium

Coastal

altissimum

Piedmont

Solidago racemosa

Piedmont

Baccharis halimifola

Coastal

Eclipta alba

Helianthus dowellianus

Piedmont

At the upper end of the Chain Bridge flats is High Island, formerly one of the best studied and most interesting spots in the Washington region. It has since been spoiled and is no longer a Mecca for biologists. Ward gives a fine account of the island, and mentions alsu features of interest of the Feeder Dam Island and other low islands just above High Island. ${ }^{73}$ Of all the Upper Potomac Islands Plummer's Island, the home of the Washington Biologists' Field Club, is best known from a natural history standpoint. The Club named has occupied the island since 1901, and one of its chief objects, at all times, has been to work up the fauna and flora of the island ${ }^{74}$ and nearby river valley.

No fewer than 290 articles have been published that treat at greater or less length the fauna of Plummer's Island. Less has been recorded relating to the plants, but they have been studied, and at least one new species Iresine rhizomatosı described. In the articles upon the fauna up to and including the year 1916 the approximate total number of forms described from Plummer's Island was: species, 158; varieties, 10 ; genera, 14; and families, 3 . Two of the new families have belonged to the Hymenoptera and one to the 'Thysanoptera.

\footnotetext{
${ }^{73}$ The valley of Cabin John Creek, which empties into the river from the Maryland side not far above High Island, has proved to le a good collecting place. Eryngium aquaticum has been found only here, and Solidago rigida is shared with but one other spot. A number of species of flies, mostly midges (Chironomidae) have been described from this valley, and a new genus of deer flies, related to Chrysops, has been collected only here. The same is true of the flower fiy, Chilosia cyanescens, and another species, Orphnephila testacel, the only representative of its family in our region.

'4 See Members' Book of the Washington Biologists' Field Club. Revised Edition, 1913.
} 
A report on the fishes of Plummer's Island and vicinity has been published, treating 54 species, and one on the thrips or Thysanoptera comprising 57 species from the island and 8 additional from neighboring areas. An account of the flower-flies or Syrphidae of the Washington area, includes a statement to the effect that 70 species of this family have been collected upon Plummer's Island and 39 others from the adjacent river valley.

A list of the Orthoptera or insects related to the grasshoppers and crickets is in press, in which 72 species are recorded from the island and 32 others from the surrounding region. In other groups the total number of species thus far collected upon the island are about: Mammals, 27; birds, 150 ; reptiles, 18 ; amphibians, 12 ; bugs, 450 ; flies, 500 ; and beetles, 1,500. The area of the island is only about 12 acres.

From the wealth of material that 'sas been collected, it is difficult to pick out things deserving special comment. The two new families of hymenoptera-the Vanhorniidae and Myersiidae, both named for their collectors-cannot be overlooked, for new families are not discovered every day. Among other insects worthy of mention are the Lygaeid bug, Tempyra biguttula, the nearest collecting station for which is in Texas; and the little jumping bug, Glyptocombus saltator, both genus and species being described from Plummer's Island, where only it has been collected. Among Neuroptera the earwig fly, Merope tuber, and the lacewing fly, Meleoma signoretti, both of northern distribution, are notable. The latter species, at the time of its capture here, had been taken no nearer than in the White Mountains. Beetles of particular interest are Chionanthobius schwarzi, genus and species described from Plummer's Island, a weevil that breeds in fruits of the fringe tree, and another weevil, Hormops abducens, not previously collected north of Florida. Flies of most note that have been taken on the island are the early spring flower fly, Merapioidus villosus, known previously only from type material, and the blood-sucking moth fly, Flebotomus vexator, the occurrence of which on Plummer's Island was the first record of the genus in the United States. It is remarkable that two mammals have been col- 
lected on and near the island, that it was necessary to describe as new species. They are, respectively, the bat, Myotis winnemana, and the shrew, Microsorex winnemana. ${ }^{75}$

The river shores near Plummer's Island, while not so assiduously explored as the island, have yielded many interesting species. From the Virginia side may be mentioned the southern flower fly Meromacrus cruciger, the beetles Cychrus andrewsii and Pterostichus approximatus, and the cicada, Melampsalta parvula. The Maryland shore has yielded specimens unique in local collections of the small locustid, Falcicula hebardi, and of the robber fly, Proctacanthus rufiventris.

Upstream from Plummers Island are: the so-called Pinnatifidum bluff, sole locality for the little fern, Asplenium pinnatifidum, Stubblefield Falls, on the bluff near which grows sweet birch, Betula lenta, the mouth of Scotts Run, notable for its fine colonies of hemlocks and walking fern, Cupid's Bower Island, ${ }^{75}$ with a fine stand of large hollies (Ilex opaca) and Difficult Run, an interesting locality and excellent collecting spot, where a few species have exclusively been collected, examples being Scutellaria versicolor, Dasystoma laevigata, and Cirsium virginianum.

A short distance above Difficult Run begins the Great Falls vicinity, one of the best marked and most interesting collecting areas in the whole Washington region. No reason is apparent why the environs of this chief fall and greatest rock-bound gorge of the Potomac should be the sole haunt in our area of so many species of animals and plants, but the fact remains that the area is thus very strongly characterized. Only in this stretch of the river valley have been found such shrubs as Rhus aromatica, Viburnum pubescens and Prunus pumila. Two rock-loving plants, Selaginella rupestris and Polypodium polypodioides, have been collected solely at Great Falls, and they are associated with a cliff flora, which, though not peculiar, is characteristic. This assemblage includes also the hairy fern, Cheilanthes lanosa;

\footnotetext{
75 This name is derived from the language of the Indian tribes which once inhabited the region; it signifies beautiful island.

76 The roach (Cryptocercus punctulatus) has been found only here.
} 
the live-for-ever, Sedum telephioides, Phlox subulata, and prickly pear. The rock pools harbor distinctive aquatics among which are Isoetes engelmanni valida, Naias gracillima and Callitriche autumnalis. A fuller list of the most interesting plants follows:

\section{CHARACTERISTIC PLANTS OF THE GREAT FALLS REGION WITH NOTES ON THE DISTRIBUTIONAL RELATION- SHIPS OF SOME OF THEM.}

Asplenium montanum Piedmont ${ }^{72}$

Cheilanthes lanosa Piedmont

Polypodium polypodioides Coastal

Selaginella rupestris Piedmont

Isoetes engelmanni valida Piedmont

Typha angustifolia Coastal

Potamogeton diversifolius

Naias gracillima Piedmont

Muhlenbergia capillaris filipes Coastal

Stipa avenacea

Danthonia compressa Piedmont

Gymnopogon ambiguus Coastal

Fimbristylis baldwiniana Coastal

Rhynchospora corniculata Coastal

Carex decomposita davisi

Ibidium plantagineum Piedmont

Salix wardi Coastal

Quercus michauxii Coastal

Paronychia dichotoma Piedmont
Brasenia schreberi

Trautvetteria carolinensis Piedmont

Neobeckia aquatica

Sedum telephioides Piedmont

Rubus odoratus Piedmont

Prunus pumila Piedmont

Lathyrus venosus Piedmont

Polygala ambigua Piedmont polygama

Callitriche antumnalis

Rhus aromatica Piedmont

Ilex decidua Coastal

Vitis rupestris Piedmont

Napaea dioica Piedmont

Viola pallens Piedmont

Opuntia opuntia Coastal

Steironema hybridum Gratiola virginiana

Viburnum pubescens Piedmont

Eupatorium semiserratum Coastal

Solidago racemosa Piedmont 
Great Falls is distinguished zoologically as well as botanically, for as previously mentioned, the Falls is the upstream limit of 3 species of anadromous fishes, and the only credible record, and that an ancient one, for the rattlesnake, is for Great Falls. So far as insects are concerned, this vicinity is an excellent collecting place. It is an especially good locality for the following scarce robber flies: Lasiopogon tetragrammica, Nicocles pictus, Nusa fulvicauda, Lampria bicolor, and Asilus maneei. The deer fly, Chrysops dimmocki, has been collected only at Great Falls in our region; and the same is true of the leptids, Rachicerus obscuripennis and $R$. nitida, and the syrphids, Microdon aurulentus and Pelecocera pergandei. Among Hemiptera the small cicada, Tettigia hieroglyphica, and the scutellerid, Acantholoma denticulata, have been collected solely near Great Falls, and among beetles the clerid, Pyticera quadripunctata. The earwig, Doru aculeatum, has been taken exclusively in a small swamp on the Virginia shore here, and the large velvet ant, Dasymutilla occidentalis, has been observed more plentifully along the towpath on the Maryland shore than elsewhere.

In conclusion let it be understood that the collecting localities treated in the foregoing paragraphs, even if added to those described by Ward and Coues, do not exhaust the list of favorable collecting places in the Washington region. Most interesting spots undoubtedly yet await exploration. Other things being reasonably equal, the amount of good collecting done determines the rank and relative interest of the various localities. The many good things discovered on Plummer's Island, for instance, were brought to light by the most intensive collecting that has been done on any area of equal extent in our region. The rewards for collecting in any even partly unspoiled neighborhood seem to be in proportion to the efforts put forth. May our entire area be made to yield the maximum of species, facts and interesting experiences, but may none of it be ravished of its natural. charms. 
ACKNOWLEDGMENTS.

The writer appreciates very much the help of the following persons in checking up the contents of the preceding three chapters: Messrs. W. R. Maxon, E. A. Preble and E. S. Steele, each of whom read all three; Mrs. Agnes Chase, and Drs. Witmer Stone and E. T. Wherry, who read the first two. Mr. N. H. Darton kindly corrected statements regarding geology and Mr. G. P. VanEseltine checked remarks on the genus, Carex. 


\section{INDEX TO THE U. S. GEOLOGICAL SURVEY'S 1917 MAP OF WASHINGTON AND VICINITY.}

\section{INTRODUCTION.}

The desirability of preparing an indexed map of the region usually considered as appertaining to the Washington fauna and flora has long been appreciated by the writer. Lack of a suitable base, however, has prevented action upon the plan until the excellent new map ${ }^{77}$ of Washington and vicinity was published. Although this map does not include the full area, taken in by the varying radii of from 10 to 25 miles used by the different workers, the opportunity seemed the best likely to come within a reasonable period, a fact recognized by the Council of the Biological Society which cheerfully gave the necessary cooperation of financial guarantees.

The plan has been to index not only all localities named on the base map, but to show by means of the index symbols the location of as many other places as possible, especially those of interest in connection with all branches of the natural history of the region. All of the old collecting spots that could be traced and located, all of the archaeological and anthropological sites and minor topographical details as springs, etc., have, so far as practicable, been indexed.

For the purpose of indexing, the original map $(413 / 4$ by $463 / 4$ inches in size) was quartered. ${ }^{78}$ The center of the map is at a point not far west of the Massachusetts Avenue bridge over Rock Creek. From that point the territory covered by the map extends approximately $11 \frac{1}{2}$ miles to the north and to the south and 10 miles to the east and west. Upon each quarter of the map, squares 23 by 20 in number, have been outlined in red. Each of these units therefore takes in an area approximately $1 / 2$ mile square.

The quarters of the large map are designated by the ini-

77 Washington and Vicinity. Maryland, District of Columbia, Virginia. U. S. Geological Survey, 1917.

${ }^{78}$ Maps are contained in a pocket attached to back cover. 
tials NW, NE, SW and SE printed upon a surface exposed after folding. The vertical rows of squares into which each quarter is divided are designated by letters from $\mathbf{A}$ to $\mathbf{T}$ and the horizontal rows br numbers from 1 to 23 . Indexing to squares is br the familiar method, and capitals exclusively are used. For closer indexing, where desirable, each unit square has the four quarters formed by imaginary lines bisecting the sides, designated (always in lower case), as $a, b, c, d$, thus: $\left|\frac{a}{c}\right| \frac{b}{d} \mid$ For instance, Glen Echo is at NW, $\mathrm{L} 17 \mathrm{~b} ; \mathrm{NW}$ indicating the map quarter, L and 17 the abscissae to be followed to their intersection, and $b$ the quadrant of the square so reached. It should be explained that the lower case letter for close indexing is not used for places actually named on the map.

In the processes of quartering and ruling the maps slight variations were unavoidable. Indexing was done on a nearly perfect set, however, and in using the index allowance may be made for any notable shifting of the ruling that may be observed on the maps in hand.

It has been found desirable to group certain items in the index and the following general headings: Building, Fort, Hill, Park, Road, School, and Water, have been adopted to cover all items naturally includible under them. Building includes everything that might be expected, except School, which itself is a complex heading. Exceptions are made in the case of Park, Fort and Hill, when they are compounded into an actual proper name of a place. To illustrate the diversity of inclusions under a single heading, those under Water may be cited: Basin, Bay, Bog, Branch, Brook, Canal, Channel, Creek ${ }^{79}$ Ditch, Falls, Flow, Gut, Inlet, Lake, Marsh, Pond, Pool, Race, Reservoir, River, Run, Spring, ${ }^{80}$ Swamp, and Water.

\footnotetext{
73 In local usage the tidal portion of tributaries of the Potomac below Washington is typically called the creek, while the upper portion is called the run: Thus, Hunting Creek, Cameron Run, Occoquan Creek, Bull Run. Variations in this practice occur, especially near Washington.

80 The number of springs in the area covered by the map is amazing. Over 100 are indexed, and probably this is not more than a tenth of the whole number.
} 


\section{BIBLIOGRAPHY.}

The following references have been used in the preparation of the index. In addition, as many place names as possible have been gleaned from publications mentioned in the bibliographies included in the Sketch of the Natural History:

Bacon-Foster, Corra.

Early Chapters in the Development of the Potomac Route to the West.

Records Columbia Hist. Soc. 15, 1912, pp. 96-322, Pls. 7-20.

Baker, Marcus.

The Boundary Monuments of the District of Columbia.

Records of the Columbia Historical Society 1, pp. 215-224, May 11, 1897.

Set in 1791-2 by Major Andrew Ellicott.

Bryan, W. B.

Bibliography of the District of Columbia being a list of books, maps, and newspapers, including articles in magazines and other publications to 1898 . $211 \mathrm{pp}$. Washington, Govt. Printing Office, 1900.

A history of the National Capital from its foundation through the period of the adoption of the Organic Act I, 1790-1814. 1914, 669 pp., 4 maps, 2 pls.

Has much on early ownership of land now the District of Columbia.

Busey, S. C.

Picture of the City of Washington in the Past. $1898,384 \mathrm{pp}$.

Contains among other things notes on old homes and seats in the vicinity which explains many place names now in use.

Casselman, A. B.

The Virginia Portion of the District of Columbia.

Rec. Columbia Hist. Soc. 12, 1909, pp. 115-141, 1 map.

The retrocession from various points of view. 
Coues, Elliott, and Prentiss, D. Webster.

Avifauna Columbiana, * * * Second Edition.

Bul. 26, U. S. Nat. Mus., 1883, 133 pp.

Chapter II, Location and Topography of the District of Columbia, pp. 11-27, is of especial interest in the present connection.

Guide to Washington, and its scientific institutions.

International Congr. of Geologists. Fifth Session, Washington, 1891.

Prepared by the Local Committee. 64 pp., 2 maps, one the geological sheet of Washington folio.

Chapter on Geology of Washington and vicinity, pp. 38-64.

Mooney, James; Babcock, Wm. H.; Holmes, W. H.; Phillips, W. W. Hallett, and Ward, Lester F.

Geographic nomenclature of the District of Columbia.

American Anthropologist 6, No. 1, Jan., 1893, pp. 29-52.

Recommendations as to names of streets, alleys, circles, bridges, roads, streams, etc. A number of Ward's names for places in Rock Creek Park are explained. Suitable names from the District flora and fauna and from the Powhatan language are listed.

Parker, H. N., Willis, Bailey, Bolster, R. H., Ashe, W. W., and Marsh, M. C.

The Potomac River Basin. Geographic History-Rainfall and stream flow-Pollution, typhoid fever and character of water-Relation of soils and forest cover to quality and quantity of surface water-Effect of industrial wastes on fishes.

Water-Supply and Irrigation Paper No. 192, U. S. Geol. Survey, 1907,364 pp. 6 maps and profiles.

Phillips, P. Lee.

List of maps and views of Washington and District of Columbia in the Library of Congress.

56th Congress, Senate Document No. 154, 77 pp., 1900.

The beginnings ô Washington as described in books, maps and views. 1917,78 pp., 24 pls.

View of Washington showing original land holdings and their names.

Proudfit, S. V.

A collection of stone implements from the District of Columbia.

Proc. U. S. Nat. Mus. 13, 1890, pp. 187-194, Pls. 10-14.

Contains "Map of the District of Columbia, showing ancient village sites, etc." 
Rand, MicNally \& Co.

Pictorial Guide to Washington, including complete descriptions of the Capitol, Library of Congress, White House, the Departments, Mount Vernon, Arlington, and all other points of interest. 1909. 195 pp., 1 map.

Rives, J. T.

Old families and houses-Greenleaf's Point.

Records Columbia Hist. Soc. 5, 1902, pp. 54-63.

Rogers, Wm. E.

The Historic Potomac River.

Records Columbia Hist. Soc. 16, 1913, pp. 25-63.

Saul, John A.

Tree Culture, or a sketch of nurseries in the District of Columbia.

Rec. Columbia Hist. Soc. 10, 1907, pp. 30-62, 6 pls.

Shoemaker, Louis $P$.

Historic Rock Creek.

Records Columbia Hist. Soc. 12, 1909, pp. 38-52.

Patterson Paper Mill just above $\mathrm{P}$ Street bridge, then known as

Paper Mill Bridge. A mill on Rock Creek just above Blagden's was known as White's \& Peter's Mill, and the surroundings as Crystal Springs Tract. Pierce Mill was known also as Shoemaker Mill.

Snowden, W. H.

Some old Historic Landmarks of Virginia and Maryland. Fourth Edition, 1902. 124 pp.

Standard Guide (cover title). Washington, the Nation's Capital, 1904, 167 text pp., 200 illus. 1 map.

Stewart, John.

Early maps and surveyors of the city of Washington, D. C.

Records of the Columbia Historical Society 2, 1895, pp. 48-71.

Taggart, Hugh T.

Old Georgetown.

Rec. Columbia Hist. Soc. 11, 1908, pp. 120-224.

Espiritu Santo, name of early Spanish voyagers for the Potomac.

A map by Noel, London, shows the upper Potomac as a tributary of Anacostia River and called Turkey Buzzard Run. The Point at Arsenal was called Turliey Buzzard Point and since has been called Youngs, Greenleafs and Arsenal Point. Anacostian Ids. included 
Analostan or Masons Id., and Alexanders or Holmes Id. Analostan also called My Lords Id., and Barbadoes. St. Elizabeth was the name of a land-grant in 1663; names of others of these old grants persist, as Giesborough, Rock of Dumbarton, Argyle, Mount Pleasant and Pleasant Plains. A grant in 1664 is for a tract of land called Rome situated on the Tiber. Georgetown founded in 1751. Rolling roads were those on which tobacco was transported in hogsheads mounted on axles. Saw Pit Landing was at Georgetown side of mouth of Rock Creek. Early names of Easby's Point are Cedar, Windmill and Peter's Point. A wharf at Braddock's Rock was called The Key of all Keys, a corruption of the Quay of all Quays.

Tindall, William.

The origin of the parking system of this city.

Records of the Columbia Historical Society 4, 1901, pp. 75-99.

Ward, Lester F.

Guide to the flora of Washington and vicinity.

Bul. 22, U. S. National Museum, 1881, 264 pp., 1 map.

"Localities of special interest to the botanist," pp. 17-26 is valuable. So far as they pertain to the area of the present map all localities shown on Ward's map, or listed in his text or in that of the six supplements that have been published have been indexed.

Woodward, Fred E.

A ramble along the Boundary Stones of the District of Columbia with a Camera.

Rec. Columbia Hist. Soc. 10, 1907, pp. 63-87, 14 pls.

Illustrates 26 stones.

With a camera over the old District Boundary Lines.

Rec. Columbia Hist. Soc. 11, 1908, pp. 1-15, 9 pls.

Illustrates 14 stones or their sites; sketch map of boundary line in Virginia.

The recovery of the Southern Corner Stone of the District.

Records Columbia Hist. Soc. 18, 1915, pp. 16-24, Pl. 1.

\section{LIST OF MAPS USED.}

Data from the following maps, so far as it differed from that on the base map, has been incorporated into the index. Reprints of early maps are cited under the entries for 1852 and 1877 :

1845.

Plan of the town of Alexandria, D. C., with the Environs, exhibiting the outlet of the Alexandria Canal, the Shipping Channel, wharves, Hunting Cr., etc. From actual survey by Maskell C. Ewing, Civ. Engr., 1845. 
1852.

Maps of the District of Columbia and City of Washington and Plats of the Squares and Lots of the City of Washington. Printed in pursuance of a resolution of the Senate of the United States, 1852. Contains 3 large maps as follows: Map of the City of Washington in the District of Columbia, Established as the Permanent Seat of the Government of the United States of America, 1839; Reprint of map of the Territory of Columbia by Andrew Ellicott (1793) ?; Plan of the City of Washington in the Territory of Columbia ceded by the States of Virginia and Maryland to the United States of America and by them established as the seat of their Government after the year 1800 .

\section{1.}

Topographical Map of the District of Columbia, surveyed in the years 1856, ' 57 , ' 58 and ' 59 by A. Boschke.

1864. ?

Environs of Washington. Prepared from original Surveys in the [U. S.] Engineers' Department.

1865.

Defenses of Washington. Extract of military map of n.e. Virginia showing forts and roads, 1865.

1870.

Plan of the City of Washington in the District of Columbia established as the Permanent Seat of the Government of the United States, extended to embrace the Suburban towns, Villages, etc., and the City of Georgetown and showing original and other valuable data not to be found on any maps heretofore published. Also a diagram of the Avenues showing their true courses and distances and a plan of Alexandria. By William Forsyth, 1870.

1877.

City Atlas of Alexandria, Va., from official records, private plans and actual surveys, based upon plans deposited in the Department of Surveys. G. M. Hopkins, 1877.

Includes copy of Plan of Alexandria Town, 1749.

1879.

Atlas of fifteen miles around Washington including the Counties of Fairfax and Alexandria, Virginia, compiled, drawn and published from Actual Surveys by G. M. Hopkins, C. E. Philadelphia, 1879.

1882.

Map of Washington and vicinity. Prepared at the office of the U. S. Geological Survey. 1882.

In Ward, Lester F. Guide to the Flora of Washington and vicinity. Bul. 26, U. S. Nat. Mus., 1881. 
1887.

Map of Washington, D. C., and Environs, with marginal numbers *** by Axel Silversparre, C. E.

1889.

Topographical map of the District of Columbia, and a portion of Virginia, revised and corrected under the direction Major Chas. W. Raymond, Corps of Engineers, Engineer Commissioner D. C., by Captain T. W. Symons, Corps of Engineers, 1889. Authorities: Original map compiled under the direction of Maj. G. J. Lydecker by Capt. F. V. Greene, 1884. Topographical maps of the District of Columbia made for the Commissioners, D. C., by the U. S. Coast and Geodetic Survey, 1879-1884, J. W. Donn, Assistant C. and G. Survey. Military maps made by the Engineer Department, U. S. Army, 1861-65. Boschke's map of the District of Columbia, 1861. Carpenter's Assessment maps, 1882.

1891.

Map of the District of Columbia and adjacent portions of Maryland and Virginia. Thos. J. Fisher and Co., 1891. Prepared by W. Kesley Schoepf.

1892.

United States Coast and Geodetic Survey. Topographic Map of the District of Columbia. Scale, 1:4800. Incomplete.

1892.

Map of the District of Columbia and vicinity, showing the principal points of interest, including the present condition of the Defenses of Washington. Compiled from the latest maps and from original surveys and reconnoissances by the Engineering Platoon of the Engineer Corps, D. C. N. G. F. L. Averill, C.E., First Lieut. Comdg. Platoon, 1892.

1894.

District of Columbia. Surveyed between 1880 and 1892 . Coast and Geodetic Survey. Scale, 1:9600 Incomplete.

1894.

Laurel Sheet, Maryland, Reconnoissance Map. [Topographic Atlas of the United States] U. S. Geol. Survey, 1894. Reprinted 1906.

1894.

Map of the City of Washington showing the Public Reservations under control of Office of Public Buildings and Grounds, prepared under the direction of Colonel John M. Wilson, Lieut. Col. Corps of Engineers, U. S. A., in charge of Public Buildings and Grounds, 1894. John Stewart, C. E. Surveyor and Draughtsman.

1894.

Frederick Sheet. Maryland-Virginia. Reconnoissance Map. [Topographic Atlas of the United States.] U. S. Geol. Survey, 1894. Reprinted 1906. 
1896.

Roberts' Road Map of the District of Columbia and adjoining portions of Maryland and Virginia, 1896, W. F. Roberts.

This is Ward's 1882 Map with a few additions, and the roads marked to indicate their quality.

1897.

Mt. Vernon Sheet. Virginia-Maryland, Reconnoissance Map. [Topographic Atlas of the United States.] U. S. Geol. Survey, 1897. Reprinted 1898.

1901.

Washington Folio. District of Columbia, Maryland-Virginia. Geologic Atlas of the United States. Folio 70, Library Edition. U. S. Geol. Survey, 1901. 4 pp., 5 maps.

Contains 1 Topographic, 1 Physiographic and 3 Geologic maps. 1903.

Map of Prince Georges County and District of Columbia showing the Topography and Election Districts. Maryland Geological Survey, 1903.

1906.

Map of Rock Creek Park showing Roads and Bridle Paths. Nov., 1906. Compiled under the direction of the Rock Creek Park Board of Control, John Biddle, Major, Corps of Eng'rs., U. S. A., Secretary.

1907.

Patuxent Folio. Maryland-District of Columbia. Geologic Atlas of the United States. Folio 152, U. S. Geol. Survey, 1907. 12 pp., 3 maps.

1909.

New Index Map of Washington, D. C. Compiled from Official Surveys, Private Plans and best authorities. 1909 (?). Brentano's.

Contains a good street index. 1910.

Map of Fairfax County, Virginia, compiled by Columbus D. Choate, 1910.

1910.

Map of Montgomery County and District of Columbia showing the topography and Election Districts. Maryland Geological Survey, 1910.

1915.

Rural Delivery Routes. Fairfax County, Va. Postoffice Department, 1915.

1915.

Potomac River, Great Falls to Little Falls, and adjoining parts of Maryland and Virginia. W. L. McAtee in McAtee, W. L., and Weed, A. C. First List of the fishes of the vicinity of Plummer's Island, 
Maryland. Proc. Biol. Soc. Wash. 28, pp. 1-14, Pls. 1-2, Feb. 12, 1915. The map also separately printed.

1916.

Soil Map. Maryland, Montgomery County Sheet.

In Soil Survey of Montgomery County, Maryland, by W. T. Carter, Jr., and J. P. D. Hull, U. S. Bureau of Soils, March 25, 1916. 39 pp., 5 pls., 1 fig., 1 map.

1917.

Soil Map. Virginia, Fairfax-Alexandria Counties Sheet. In Soil Survey of Fairfax and Alexandria Counties, Virginia, by W. T. Carter, Jr., and C. K. Yingling, Jr., U. S. Bureau of Soils, 1917, 43 pp., 4 pls., 1 fig., 1 map.

\section{PERSONAL OBLIGATIONS.}

The writer is greatly obliged to the following persons who have cooperated in making the index as complete as practicable: E. S. Burgess, A. K. Fisher, Gustavus A. Gambs, H. W. Henshaw, W. R. Maxon, William Palmer, E. A. Preble, E. S. Steele, Geo. B. Sudworth, and Ewing Summers.

\section{INDEX. ${ }^{81}$}

A.

Abingdon, birthplace of Nellie Custis, SE, B $9 \mathrm{~b}$.

Academy, see under School.

Addison, or Addison Heights, SE, A 9.

$\Lambda$ gassiz Park, SE, L 7 .

Alexandria (County Seat Fairfax County, 1754-1800), SE, ABC 15, 16, 17.

Alexandria Light or Lighthouse, SE, C 18a.

Alta Vista, NW, O 11.

Alton Farm, NE, D 11 d.

American University Park, NW, Q 19.

Ammendale, NE, R 5.

Anacostia, SE, HI 7, 8.

Annandale, SW, F 12. (Last fight on Virginia soil, in Civil War, here April 10, 1865.)

Ardwick, NE, T 20.

Arlington Estate-A r ling to n Cemetery.
Arlington Heights-Vicinity Arlington $\mathrm{P}$. $\mathrm{O}$.

Arlington Junction, SE, A 8.

Arlington Mills-Barcroft.

Arlington P. O., SW, R 8 .

Arlington Sta., SW, T 5.

Arlington Sta., old name for Barcroft.

Arlington Wireless Sta., SW, S 7.

Armory, see under Building.

Arsenal, see under Building.

Ashdale, SW, K 5.

Ash Grove, NW, A 21.

Asylum, see under Building.

Aubreys Ferry-Masons Ferry.

Aurora Heights, SW, R 4.

Aurora Hills, SE, A 10.

Autrey Park, NW, M 2.

Avalon, or Avalon Heights, NE, $\mathrm{K} 22 \mathrm{c}$.

Avenel, NE, I 11.

Avenue, see under Road.

81 Users of the index are invited to communicate to W. L. McAtee, Biological Survey, locality names which should be added to the index. If sufficient accumulate a supplement will be issued. 
B.

Bailys Corners-Baileys Crossroads.

Baileys Crossroads, SW, M 10.

Balls Crossroads-Ballston.

Balls Hill, NW, F 20.

Ballston, SW, O 5.

Barcroft, SW, O 9b.

Barkers Crossroads, SW, D 22.

Barracks, see under Building.

Basin, see under Water.

Bathing Beach (on Tidal Basin), SE, C 5a.

Battery, see under Fort.

Bay, see under Water.

Beane, NW, N 9.

Bellaire, SW, P 5d.

Belle Haven, an old name for Alexandria (1669).

Belleview, NW, A 17.

Bellevue, NW, C 12.

Bellmont-Warwick.

Bell's Mill, NW, J 9.

Beltsville, NE, Q 7.

Bench marks (altitudes in black type).

$15 \mathrm{SE}, \mathrm{B} 4$

16 SE, G 22

21 SE,OP 1

30 SW, S 11

31 SE, A 12

36 SE, A 12

$46 \mathrm{SW}, \mathrm{T} 11$

$46 \mathrm{NW}, \mathrm{O} 22$

$47 \mathrm{SE}, \mathrm{C} 16$

$52 \mathrm{NE}, \mathrm{N} 17$

53 NE, N 16

$53 \mathrm{NE}, \mathrm{O} 14$

55 SW, P 16

$61 \mathrm{NW}, \mathrm{L} 16$

$62 \mathrm{NW}, \mathrm{L} 17$

62 SW, S 3

66 NE, P 12

69 NW, J 16

77 NW, I 16

85 NW, I 16

93 NW, I 16

$101 \mathrm{NE}, \mathrm{Q} 8$

$102 \mathrm{NW}, \mathrm{H} 16$

109 NW, H 16

117 NV, H 16

118 NIV, G 16

119 NW, B 14

119 NIV, G 16

119 NW, E 15

120 NW, F 16

121 NW, B 14

126 NW, A 13
133 SW, P 11

134 NW, A 13

135 NIV, A 13

142 NW, A 12

145 SW, T 7

150 NW, A 12

150 SE, R 5

152 SW, R 3

158 SE, S 5

159 NW, A 12

171 NIV, A 12

182 NE, Q 5

190 SWV, Q 3

$191 \mathrm{SE}, \mathrm{T} 5$

193 SW, R 13

205 N.E, G 18

222 SW, R 3

222 SW, R 4

$230 \mathrm{NW}, \mathrm{M} 20$

239 SE, P 22

241 SE, L 22

244 SE, R 21

$246 \mathrm{SE}, \mathrm{O} 23$

249 SE, R 18

$252 \mathrm{SE}, \mathrm{T} 13$

266 SE, Q 16

267 SW, P 3 .

$267 \mathrm{NW}, \mathrm{K} 20$

$268 \mathrm{SE}, \mathrm{T} 14$

$275 \mathrm{NW}, \mathrm{J} 19$

279 NE, N 3
$165 \mathrm{NW}, \mathrm{L} 1 \mathrm{~S}$
Bench marks-Continued.

285 NW, H 21374 SW, A 11

289 SW, B $17 \quad 399$ SW, F 3

300 NW, Q $18 \quad 403$ SW, N 3

318 SW, B $10 \quad 414$ NE, L 1

323 SW, A $17 \quad 421$ SW, C 4

333 NW, F $22 \quad 429$ SW, E 2

$335 \mathrm{SW}, \mathrm{B} 9 \quad 450 \mathrm{SW}, \mathrm{D} 1$

$362 \mathrm{SW}, \mathrm{C} 6 \quad 459 \mathrm{NE}, \mathrm{B} 6$

$364 \mathrm{SW}, \mathrm{O} 3 \quad 476 \mathrm{SW}, \mathrm{C} 2$

366 NW, F 22483 NW, B 23

Benning, SE, MN 3

Benning Race Course, SE, LM 2.

Berry's Woods, NE, G 22a.

Berwyn, NE, O 12, 13.

Berwyn Heights, NE, PQ 13.

Bethesda, NW, Q 14.

Bladensburg, NE, N 20.

Blithewood P. O., NE, R 21.

Bluemont Junction, SW, M 7.

Bolivar, SW, P 5c.

Bon Air, SW, M 7.

Bosford Camp, SW, L 11a.

Boulevard Heights, SE, N 7.

Boundary-Florida Avenue.

Boundary Line, Alexandria and Fairfax Counties, Virginia. NW, N 21 to L 23.

SW, L 1 to I 4 to $\mathrm{T} 14$.

Boundary Line, District of Columbia and Maryland.

NW, T 15 to L 23.

$\mathrm{NE}, \mathrm{C} 13$ to $\mathrm{A} 15$ and $\mathrm{N} 23$.

$\mathrm{SE}, \mathrm{N} 1$ to $\mathrm{Q} 4$ and $\mathrm{C} 18$.

Boundary Line, District of Columbia and Virginia.

$\mathrm{NW}, \mathrm{N} 21$ to $\mathrm{P} 23$.

$\mathrm{SW}, \mathrm{P} 1$ to $\mathrm{T} 5$.

SE, A 5 to C 18.

Boundary Line, Maryland and Virginia.

$\mathrm{NW}, \mathrm{A} 8$ to $\mathrm{N} 21$.

SE, C 18 to B 23 .

Boundary Line, Montgomery and Prince Georges Counties, Md. $\mathrm{NE}, \mathrm{O} 1$ to $\mathrm{F} 16$.

Bradbury Heights.

SE, N 7.

Braddock.

SE, A 14.

SW, T 14.

Braddock Heights-Braddock.

Braddock Rock, SE, B 4.

Bradley Hills Park, NW, A 12.

Boundary Stones.

Northwest Side of District.

$1 \mathrm{SW}, \mathrm{J} 2$.

2 SW, L 1. 
3 NW, M 22.

4 NIV, O 21.

$5 \mathrm{NW}, \mathrm{P} 20$

$6 \mathrm{NW}, \mathrm{Q} 18$.

$7 \mathrm{NW}, \mathrm{S} 17$.

$8 \mathrm{NW}, \mathrm{T} 15$.

9 NE, A 14.

North corner, NE, C 13.

Northeast Side of District.

$1 \mathrm{NE}, \mathrm{D} 14$.

2 NE, F 15.

$3 \mathrm{NE}, \mathrm{G} 17$.

4 NE, H 18.

5 NE, J 20.

$6 \mathrm{NE}, \mathrm{K} 21$.

7 NE, M 22.

8 SE, N 1.

9 SE $O 2$.

East Corner, SE, Q 4

Southeast Side of District.

$1 \mathrm{SE}, 0$ 5.

2 SE, N 7.

3 SE, M 8.

4 SE, K 10.

$5 \mathrm{SE}, \mathrm{J} 11$.

6 SE, H 12.

7 SE, G 14.

8 SE, F 15.

9 SE, D 16.

South Corner, SE, C 18.

Southwest Side of District.

3 SW, S 14.

$6 \mathrm{SW}, \mathrm{N} 9$.

7 SW, M 8.

$9 \mathrm{SW}, \mathrm{J} 5$.

West Corner, SW, I 4.

Branch, see under Water.

Branchville, NE, P 12.

Brentwood, NE, MI 20.

Brick Haven, SE, A Sa.

Bridge, Anacostia, SE, H 7 .

Bridge, Aqueduct, SW, T 2, 3.

Bridge, Arch or Union ArchCabin John Bridge.

Bridge, Benning, SE, K 3.

Bridge, Boulder, NE, B 19d.

Bridge, Cabin John, NW, K 16.

Bridge, Chain, NW, O 22.

Bridge, Connecticut Avenue, NE, B 23.

Bridge, Free-Aqueduct Bridge.

Bridge, High - Calvert Street Bridge, NE, B 23a.

Brige, Highway, SE, BC 6, 7.

Bridge, Long, SE, C 6,7 .

Bridge, Low - Woodley Park Bridge.

Bridge, Massachusetts Avenue, NW, A 23.
Bridge, Navy Yard-Anacostia Bridge.

Bridge, Owl, NE, K 18c.

Bridge, Paper Mill, old name for P St. Bridge, SE, B 1, 2.

Bridge, Pennsylvania Avenue, SE, IJ 6.

Bridge, Pierces Mill, NE, B 20c.

Bridge, Thompson's, NE, A 23d.

Bridge, Woodley Park, NE, B $23 \mathrm{a}$.

Bridgepoint--south end of Long Bridge.

Bridgeport-south end of Long Bridge.

Brightwood, NE, D 17.

Brightwood Park, NE, DE 18.

Brightwood Sta. was at NE, E $15 \mathrm{~d}$.

Brills-River View.

Broad Creek, SE, H 22.

Brook, see under Water.

Brookland, NE, HI 21, 22.

Blookmont, NW, O 20.

Brookside, NW, M 12d.

Brooks Sta.-Brookland.

BUILDING.

Armory, Columbia, was at 6 th and B Sts. S.W., SE, E 5-6.

Arsenal, was on site of Washington Barracks.

Asylum, German Orphan, SE, J 8.

Asylum, St. Vincent's Orphan, NE, G 23.

Barracks, Marine, SE, H $6 \mathrm{a}$.

Barracks, Washington, SE, E $7,8$.

Building, House of Representatives Office, SE, F 5b.

Building, Municipal, SE, D $4 a$.

Building, Pan American, SE, C $4 \mathrm{a}$.

Building, Red Cross, SE, C 4a.

Building, Senate Office, SE, F $4 \mathrm{~b}$.

Building, State, War and Navy, SE, C 3c.

Bureau of Engraving and Printing, SE, D 5a.

Bureau of Fisheries, SE, E 5 a.

Bureau of Standards, NW, T 20.

Cabin, Joaquin Miller, NE, B 17.

Capitol, SE, F 4d.

Chapel, Emory, NE, D 17b.

Chapel, Mt. Olivet, SW, H 19d.

Chapel, St. Cecilias, NE, J 16. 


\section{Building-Continued.}

Chapel, Stewart, NE, I 5.

Chapel, Walkers, NW, M 23.

Church, Annandale, SW, G 12.

Church, Bethesda, NW, Q 11.

Church, Broad Creek, SE, G 23.

Church, Evergreen, NW, J 6 .

Church, Gibson Grove, NW, J 14.

Church, Grace, NE, C 11a.

Church, Herman, NW, I 14.

Church, Howardsville, SW, P $13 \mathrm{~b}$.

Church, Mt. Olivet, SW, K 19c.

Church, Mt. Olivet, SW, N 4.

Church, Mt. Pisgah, NE, J 10.

Church, Oxon Hill, SE, H 16d.

Church, Pleasant Grove, NW, A 20 .

Church, Pohick, SW, B 23a.

Church, St. Barnabas, SE, K $14 \mathrm{~d}$.

Church, St. Gabriels, NW, C 11.

Church, St. Ignatius, SE, K 16.

Church, St. Johns, NW, J 22.

Church, St. Johns (1694)Broad Creek Church.

Church, St. Marks, NE, K 3.

Church, Shiloh, NW, B 21.

Church, Sitka, NE, J 9.

Church, Wakefield, SW, B 13a.

Coast and Geodetic Survey, $\mathrm{SE}, \mathrm{F} 5 \mathrm{~b}$.

Department of Agriculture, $\mathrm{SE}, \mathrm{D} 4,5$.

Department, Interior, SE, E 3c.

Department, Post Office, SE, D 4 b.

Department, Treasury, SE, C $3 d$.

Factory, Soap, SE, E 11c.

Filtration Plant, NE, F 22.

Foundry, Foxall, SW, R 2a.

Gallery, Corcoran Art, SE, C $3 c$.

Glass House, Old, s.e., cor. Water and 22d Sts. SE, B 4 d.

Government Printing Office, SE, F 3.

Guard House, Central, was at La. Ave. betw. 9th and 10th Sts. S.W., SE, D 4 b.

Hall, City, SE, E 3, 4.

Hall, Continental, SE, C 4a.

Home for the Aged and Infirm, $\mathrm{SE}, \mathrm{E} 14,15$.

\section{Building--Continued.}

Home, Lutheran, NE, I 23.

Home, Masonic and Eastern Star, NE, G 17.

Home, U. S. Soldiers, NE, F 21.

Hospital, Freedmens, NE, E 23.

Hospital, Garfield, NE, D 23b.

Hospital for the Insane, Government, SE, GH 9, 10.

Hospital, Marine, formerly on site of Workhouse, SE, J 5.

Hospital, Naval, SE, H 5c.

Hospital, St. El i za be th sGovernment Hospital for the Insane.

Hospital, Tuberculosis, NE, D 20.

Hospital, Walter Reed, NE, D 15.

Hotel, Ferry (Old), SE, D 16d.

House, Alms, SE, J 5a.

House, White, SE, C 3.

Houses, Work, SE, J 5c.

Institute for Deaf Mutes, Columbia, SE, H 2.

Institution, Smithsonian, SE, D $4 \mathrm{~d}$.

Jail, SE, J 5a.

Laboratory, Carnegie Geophysical, NE, A 20.

Laboratory, Carnegie Terrestrial Magnetism, NW, T 18.

Library of Congress, SE, G 4c.

Library, Public, SE, E 2, 3.

Lincoln Memorial, SE, B 4c.

Magazines, Army and Navy Powder, were at SE, J 5c.

Magazine, Belleview, SE, D 13.

Magazine, U. S. Powder, SE, D 13.

Manor, Holmead, was at 14th St. and Spring Road, NE, D 21a.

Mansion, Executive, SE, C 3d.

Mill, Adams, NE, B 22c.

Mills, Arlington, SW, O 9b.

Mill, Balls, NW, B $15 \mathrm{c}$.

Mill, Barcrofts, SW, L 11a.

Mill, Barton Grist, NW, P 19d.

Mill, Bells, NW, J 9.

Mill, Blagdens, NE, B 19d.

Mill, Bone, SW, E 20d.

Mills, Burnt, NE, G 8.

Mills, Clouds-Eads Mill.

Mill, Clouds-Triadelphia Mill.

Mill, Columbian, another name for Foxall Foundry. 


\section{Building-Continued.}

Mill, Custis-Arlington Mills.

Mill, Dodges, SW, T 2c.

Mill, Dominion Grist, SW, Q $16 \mathrm{~b}$.

Mill, Eads or Edes, NW, P 23d.

Mill, Hunt and Roberts Flour, SW, T $16 \mathrm{c}$.

Mill, Larges Saw, SW, G 13b.

Mill, Loughborough, NW, P $17 \mathrm{~d}$.

Mill, Lyons, SE, A $1 \mathrm{~b}$.

Mill, Nelsons, NW, K 21d.

Mill, Old, SW, L 21a; NW, B $15 \mathrm{c}$.

Mills, Old Northwest, NE, D 3.

Mill, Old Sligo, NE, H 15.

Miil, Orndorffs, old name for Bells Mill.

Mill, Patterson Paper, SE, B 1c.

Mill, Peters or Whites and old Mill, at NE, B 19d.

Mill, Pierce; another name, Shoemakers Mill, NE, B 20.

Mill, Riggs, NE, J 13.

Mill, Roachs, SW, T 11b.

Mill, Swinks, NW, E 18.

Mill, Triadelphia, SW, N 15.

Mill, Viers, NW, Q 4.

Monument, Washington, SE, C $4 \mathrm{~d}$.

Museum, U. S. Army Medical, SE, E 5a.

Museum, U. S. National.

New, SE, D 4 d.

Old, SE, DE 4, 5 .

Museum of Hygiene, U. S. Naval, SE, B $4 \mathrm{a}$.

Navy Yard, SE, GH 6, 7.

Observatory, National, was formerly at SE, AB 3, 4.

Observatory, Naval (U. S.), NW, T 23.

Observatory, Old (Steele), SE, $\mathrm{AB} 3,4$.

Office, Land, SE, E 3c.

Office, Pension, SE, E 3d.

Public Health \& Marine Hospital Service, SE, B 3 a.

Public Market, SE, DE 4.

Sanatarium, Takoma Park, NE, G 14.

Sewage Pumping Station, SE, G 6,7 .

Slave market was at 13 th and F Sts. N.W.

Slave pen was at 8 th and $B$ Sts. S.W.
Building-Continued.

Steel Plant, SE, E 10, 11.

Tavern, Dowells, SW, M 14c.

Tavern, Drove, SW, T $16 a$.

Tavern, Drovers Rest, SW, Q $1 b$.

Tavern, Old Stone, NW, Q 14d.

Tavern, Orquarts, SW, M 14c.

Tavern, Padgetts or Pagets, SW, H I, 13.

Tavern, Taylors, SW, J 7b.

Water Tower, Takoma Park, NE, G 15c.

War College, SE, E 8.

Bunker Hill, NE, H 21.

Bureau, see under Building.

Burgundy Farm, SW, Q 17c.

Burnt Mills, NE, G 8.

Burnt Mills, a name on old maps for Old Sligo Mill.

Burrville-Burtville on map.

Burtville, SE, O 3.

Bush Hill, SW, N 17.

C.

Cabin John Bridge, NW, K 16.

Cabin John P. O., NW, J 15.

Calvert Station, NE, N 17.

Cameron Ford, SW, S 17a.

Camp Springs, SE, Q 16.

Canal, see under.Water.

Capitol Heights, SE, PQ 4 to 6 .

Capitol View, NW, T 9.

Carberry Meadows (Ward), NW, $\mathrm{N} 18$ to $\mathrm{P} 23$; SW, PQ 1,2 .

Carlin Spring Pavilion-Glencarlyn.

Carlins or Carlin Springs-Glencarlyn.

Carrol Estate (Ward)-Northern corner of District of Columbia.

Carrollsburg, an old settlement on Greenleafs Point.

Carroll Springs, NE, B 10.

Causeway to Analostan Id., SW, T 3.

Cavalry Depot, Old, was on Giesboro Point.

Cedar Heights, SE, Q 3.

Cedar Lane, NW, O 12.

Cemetery, SW, S 14.

Cemetery, SE, N 5.

Cemetery, NW, T 23.

Cemetery, Arlington National, SW, ST 5, 6.

Cemetery, Battle, NW, D 17b.

Cemetery, Congressional, SE, J 5.

Cemetery, Glenwood, NE, FG 23.

Cemetery, Graceland, SE, IJ 2, 3. 
Cemetery, Harmony, NE, H 23.

Cemetery, Holmead, was bounded by $19,20, \mathrm{~S}$ and $\mathrm{U}$ Sts., NE, C 23; SE, C 1.

Cemetery, Jewish, SE, I 10.

Cemetery, Mt. Olivet, SE, I 12.

Cemetery, National, SE, A 16.

Cemetery, U. S. National Military, NE, F 20.

Cemetery, Oak Hill, SE, A 1.

Cemetery, Oakwood, SW, K 6.

Cemetery, Prospect Hill, NE, F $23 d$.

Cemetery, Rock Creek, NE, F 19.

Cemetery, St. Elizabeths, SE, HI 10.

Cemetery, St. Marks, NW, M 1.

Cemetery, St. Marys, NE, G 23.

Cemetery, U. S. Military-Arlington Cemetery.

Channel, see under Water.

Chapel, see under Building.

Charlton Hei g h t s-B e r w y n Heights.

Chautauqua-Glen Echo.

Checkerberry Bluff (Ward), NE, B 22a.

Cherrydale, SW, oP 3, 4.

Chesapeake Junction, SE, Q 4.

Chesterbrook, NW, K 23.

Chestnut Ridge, NE, D 7.

Chevy Chase, NW, S 16.

Chevy Chase, North, NW, S 12.

Chillum, NE, H 17.

Church, see under Building.

Circle, see under Park.

Claggett Estate, NE, CD 14.

Claremont, NW, G 11.

Clarendon, SW, PQ 5.

Clarenford, SW, O 5.

Clark, SW, T 7 .

Cleveland Heights-Clev e 1 a n d Park.

Cleveland Park, NW, T 21; NE. A 21.

Cliffbourne, NE, B 23.

Clinton, SE, R 21, 22.

CLUBS.

Club, Anglers, NW, C 14c.

Club, Bannockburn Golf, NW, L 16.

Club, Chevy Chase, NW, S 15.

Club, Columbia Country, NW, S 13.

Club, Lock Tavern, NW, A 12.

Club, Montgomery Country, NW, K 10.

Club, Washington Country, SW, M 2.
Clubs-Continued.

Club, Washington Suburban, NE, E 19.

Cohasset, NW, K 13d.

Colesville, NE, G 1.

College, see under School.

College Hill-Meridian Hill.

College Lawn P. O.-College Park.

College Park, NE, NO 15.

Colonial, SW, S 3b.

Colonial Heights, SW, R 3 .

Columbia Heights, NE, CD 22.

Columbia Springs, SE, A 6d.

Columbia Park, NE, S 23.

Columbia Sta., SW, R 8 .

Concord, NW, L 14.

Congress Heights, SE, GH 10, 11.

Conopholis Ridge, NE, A 23c.

Convalescent Camp, SW, R 10b, S 10a.

Cooke Park, SE, A 1c.

Corbett, SW, R 8c.

Corcorans Woods, NE, EF 22.

Cottage City, NE, M 21.

Cottage Hill, SE, IJ 2.

County Courthouse (Alexandria Co., Va.), SW, R 4.

Courthouse Sta., SW, R 5.

Courtlands-Courthouse Sta.

Cowden, SW, R 10, 11.

Cowdons Station-Cowden.

Creek, see under Water.

Cropley, NW, C 14.

Curtin, NW, O 20.

D.

Daingerfield, SW, H 18bd.

Dam, Feeder, or No. 1 of C. \& O. Canal, NW, MN 19.

Dam, Great Falls, NW, A 11, 12.

Dam, Lyons, SE, A $1 b$.

Dangerfields Fishery, SE, D 23b.

Daniels Park, NE, O 11.

Davis Quarry, probably at the site of the Bear Pit, Zoological Park, NE, B 22b.

Deaf and Dumb Institute-Columbia Institute for Deaf Mutes.

Deanewood, SE, N 2.

Decatur Heights, NE, O 20.

Del Ray or Rey, SW, T 13.

Department, see under Building.

Devils Den, NE, IJ 5 .

Ditch, see under Water.

Ditchley, SW, E 18a.

Dixie Landing, NW, 0 22a.

Dodge Park, NE, T 22.

Dominion Heights, SW, P 3, 4. 
Douglas, SW, P 4.

Drive, see under Road.

Drummond, NW, Q 16.

Dumping Grounds (Steele), was between Washington Monument and Tidal Basin.

Dunn-Loring (Station on Bluemont Line), SW, CD 4; (Station on Fairfax Line), SW, C 3.

Dupont Heights, SE, O 8.

Dyke, SE, B 22.

Eagle Rock, NW, H 16c.

Easbys Wharf, SE, A 4.

East Arlington, SW, T 7.

East Falls Church, SW, J 4.

East Lane, NE, P 18.

East Washington Heights, SE, K 8.

Eckington, NE, FG 23; SE, FG 1.

Edgemoor, NW, P 14.

Edgewood, NE, G 23; NE, P 10.

Edsall, SW, J 17.

Elkins, NW, A 14.

El Nido, NW, J 22.

Enola, SW, C 3.

Emery Corners, NW, J 13.

English Village, NW, O 14. F.

Fairfax Seminary P. O. (Ward), SW, R 14.

Fairhill, NE, 122.

Fairland, NE, L 1.

Fairmont Heights, SE, P 3.

Fairview, NW, A 15.

Fairview Heights, NW, S 21d.

Falls, see under Water.

Falls Church, SW, I 5, 6.

Farlee, SW, P 5c, d.

Farm, U. S. Experimental (Arlington), $\mathrm{SW}, \mathrm{T} 5,6$; $\mathrm{SE}$, A 6.

Farm, U. S. Experimental (Beltsville), NE, R 8 .

Faulkner Forge, NW, K 20a.

Fenwick, NE, C 12.

Ferndale, NW, I 11.

Fernwood, NE, A 20c.

Ferry Landings, SW, $\mathrm{T} 2 \mathrm{c}$ and $\mathrm{T} 3 \mathrm{a}$.

Fishing Landing, SW, S 3b.

Fishtown - northern part of Alexandria.

Flow, see under Water.

Forest Glen, NE, A 10.

Forestville, SE, T 10.

FORT.

Battery, SE, M 4.
Fort-Continued.

Battery Alexander, NW, N 19b.

Battery Bailey, NW, Q 18d.

Battery Benson, NW, P 17, 18.

Battery Cameron, SW, R 1 a.

Battery Gaines, NW, R 21a.

Battery Jameson, NE, L 22.

Battery Kingsbury, NE, B 17c.

Battery Mansfield, NW, P 18d.

Battery Martin Scott, NW, P 21c.

Battery Meade, NE, A 17d.

Battery Parrott, NW, Q 23.

Battery Reno, NW, S 18c.

Battery Ricketts, also called Fort, SE, I 9.

Battery Rodgers (site in S. E. Alexandria), SE, C 17c.

Battery Russel, NW, T 18c.

Battery Sill, NE, C 17c.

Battery Terrill, NE, A 18a.

Battery Vermont, NW, P 21.

Fort Albany, SW, T 8.

Fort Baker, SE, K 8.

Fort Barnard, SW, Q 10.

Fort Bayard, NW, R 18.

Fort Bennett, SW, S 3.

Fort Berry, SW, R 9.

Fort Buffalo, SW, J 7 .

Fort Bunker Hill, NE, H 21.

Fort Carroll, SE, F 11.

Fort Cass, SW, R 5d.

Fort Chaplin, SE, M 4.

Fort Columbia, was on Jones Point, SE, C 18.

Fort Corcoran, SW, S 3d.

Fort Craig, SW, s 7a.

Fort Davis, SE, L 7 .

Fort DeRussey, NE, B 17.

Fort Dupont, SE, M 7 .

Fort Ellsworth, SW, T 15, 16.

Fort Ethan Allen, NW, N 22.

Fort Farnsworth, SW, S 18.

Fort Foote, SE, D 21.

Fort Gaines, NW, R 20.

Fort Garesche, SW, Q 12a.

Fort Greble, SE, EF 13.

Fort Haggerty, SW, T 3c.

Fort Jackson was at south end of Long Bridge, SE, C 7a.

Fort Kearney, NE, A 18c.

Fort Kemble, NW, Q 22.

Fort Lincoln, NE, K 22.

Fort Lyons, SW, S 17, 18.

Fort McPherson, SW, T 7 .

Fort McPherson-Fort Ellsworth, SW, T 15, 16.

Fort Mahan, SE, M 3, 4.

Fort Mansfield, NW, P 18d. 
Fort-Continued.

Fort Marcy, NW, N 21.

Fort Massachusetts, an early name for Ft. Stevens.

Fort Meigs, SE, O 6.

Fort Morton, SW, R 4a.

Fort Myer (the original), SW, S $5 a$.

Fort Myer, SW, RS 5, 6.

Fort O'Rourke, SW, S 18, 19.

Fort Ramsay, SW, KL 7 .

Fort Reno, NW, S 18c.

Fort Reynolds, SW, Q 11.

Fort Richardson, SW, S 9.

Fort Runyon, SE, A 8.

Fort Runyon Sta.-Alexandria Jet.

Fort Saratoga, NE, I 22b.

Fort Scott, SE, A 10.

Fort Sedgwick, SE, N 5.

Fort Shaplin or Shiplin-Ft. Chaplin.

Fort Simmons, NW, Q 19a.

Fort Slemmer, NE, G 20.

Fort Slocum, NE, F 17.

Fort C. F. Smith, SW, Q 3.

Fort Snyder, SE, I 10.

Fort Stanton, SE, I 9.

Fort Stevens NE, D 17.

Fort Strong, SW, R 3.

Fort Sumner, NW, MN 18.

Fort Thayer, NE, J 22.

Fort Tillinghast, SW, R $6 \mathrm{~b}$.

Fort Totten, NE, G 19.

Fort Wagner, SE, J 8.

Fort Ward, SW, P 12.

Fort Weed, SW, S 18.

Fort Whipple, SW, S 5b.

Fort Willard, SW, T 19.

Fort Williams, SW, QR 15.

Fort Woodbury, SW, T 4d.

Fort Worth, SW, Q 14.

Fortifications, in 1800 , existed on Greenleaf's Point, and at site of present U. S. Naval Museum of Hygiene, SE, AB 3,4 .

Redoubt Cross, NW, N 18a.

Redoubt Kirby, NW, N 18a.

Tete Du Pont-fortifications about east end of Benning Bridge.

Fort Berry Sta., SW, R 9c.

Fort Myer Heights, SE, ST 4, 5.

Fort Myer Junction, SW, T 4a.

Fort (Myer) Steps, SW, S 5.

Fostoria, SW, L 5.

Four Corners, NE, F 9.

Four-mile Run (Sta.), SE, A 11.
Fox, SW, R 9.

Fox Ferry, SE, D 16.

Franconia, SW, J 19.

Franklin. SW, B 3.

Franklin Park, SW, K 1.

Freedmans Village, SW, T 7a.

Friendly, SE, I 23.

Friendship Heights, NW, R 17. G.

Gales Woods, SE, HI 2.

Gallery, see under Building.

Galliher, NW, N 13.

Gambrill, SW, B 23a.

Garden, see under Park.

Garfield, SE, J 9.

Garfield, SW, H 20b.

Garrett Park, NW, Q 7.

Garrison, SW, N 6.

Georgetown, SW, T 1, 2; SE, A $1,2$.

Gilman Corner, SE, H 16.

Glencarlyn, SW, MN 8.

Glendale, NW, A 16.

Glendale-Glenville on map.

Glenellan Park. NW, S 21.

Glen Echo, NW, L 17.

Glen Echo Heights, NW, M 17.

Glen Echo Junction, NW, M $18 b$.

Glen Echo P. O., NW, L 16.

Glenmont, NE, B 4.

Glen Sligo, NE, G 15.

Glenville, SE, N 4.

Good Hope, SE, JK 8.

Grasslands, NW, S 20a.

Great Falls, Md., NW, A 12.

Great Falls, Va., NW, A 13.

Green Spring Scheutzen Park, $\mathrm{SW}, \mathrm{S} 2 \mathrm{~b}$.

Green Valley, SW, R 10.

Greenwood, SW, O 3.

Grimes-Phelps Corners.

Grimesville, SE, I 17.

Ground Pine Woods, NE, B 14.

Gulf Landing, NW, O 22d.

Gut, see under Water.

$\mathrm{H}$.

Hall, see under Building.

Halls Hill, SW, N 3, 4.

Halpine, NW, N 3.

Hamburgh, an old settlement at $\mathrm{SE}, \mathrm{AB} 3,4$.

Harewood, NE, F 22a.

Harlem, SW, R 1, 2.

Harrison, SW, O 3 .

Hatfield, SW, S 6.

Havemeyer Park, SE, K 9.

Hawes Woods, site of Garfield Hospital east to 7th Street, NE, D 23-24. 
Hayes, SIV, P 4.

Hells Bottom, SE, B 7.

Hemlock Bluff, NW, E $16 \mathrm{~cd}$.

Herberts Crossroads, SW, A 17.

Heronry (Black-crowned Night) NTV, OP 20.

Highland Park-Upton.

Highlands, NE, KL 21.

Highlands (Va.)-Fostoria.

Highway, see under Road.

HILL.

Hill, Bald Eagle, SE, F 14.

Hill, Balls, NW, F 20.

Hill, Barretts, SW, F 3c.

Hill, Blagdens, NE, BC 20, 21

Hill, Braddock, SE, B 4 a.

Hill, Bunker, NE, H 21.

Hill, Camp, old name, SE, B 4 a.

Hill, Cottage, another name for Mt. Hamilton.

Hill, Freedom, NW, A 23.

Hill, Gantt, NW, B 22.

Hill, Gerardia, NE, B 22cd.

Hills, Greyet, SW, F 12.

Hill, Halls, SW, N 3, 4.

Hill, Hickey, SE, K 1.

Hill, High, SW, D 1, 2.

Hill, Johnsons, SW, ST 8 .

Hill, Linnaean, NE, B 21a.

Hill, Mackall, NW, H 21.

Hill, Mackeys, SW, S 3.

Hill, Masons, SW, K 11d.

Hill, Miner, should be Minors, SW, J 2.

Hill, Monkshood, NE, B 22c.

Hill, Mulligan or Mungers Hill-Mt. Hamilton.

Hill, Munson, SW, L 8.

Hill, Oak, SE, A 1.

Hill, Oxon, SE, I, 16 to K 14 .

Hill, Peach Grove-Gantt Hill, NW, B 22.

Hill, Perkins, SW, K 8a.

Hill, Prospect, NW, B 16.

Hill, Prospect, NW, F 17, 18.

Hill, Rock, former name for

Kalorama, SE, A 1, 2.

Hill, Rose, SW, J 12.

Hill, Rose-Soapstone Hill.

Hill, Round, SW, L 23.

Hill, Soapstone, NW, T 19d.

Hill, Shoemaker, NE, A 20.

Hill, Shuters, SW, T 15, 16.

Hill, Swallow, SE, A 10d.

Hill, Upton, SW, L 7.

Mount Eagle, SW, S 17, 18.

Mt. Erin, SW, PQ 19.

Mt. Hamilton, SE, J 1, 2.

Mt. Miller, SE, A 1.
Hilldale, NW, N 13.

Hillsdale-part of Anacostia.

Hitaffer, NW, E 19.

Hollywood, NE, O 11.

Hollywood, NW, M 12 b.

Holtzman's Landing, SW, R 2d.

Home, see under Building.

Hospital, see under Building.

Howard Park-grounds of How. ard University.

Howardtown-vicinity of Howard University.

Hume, SW, T 12, 13.

Hunter, SW, R 7b.

Huntington Terrace, NW, O 12.

Huntsville, SE, S 2.

Hyattsville, NE, MN 19, 20.

Hyson, SW, K 5 .

\section{I.}

Idylwood, SW, DE 3, 4.

Ilda, SW, A 11.

Independent Ice House, SW, S $2 c$.

Indian soapstone quarries, NW, T 19d; SW, L 6b.

Indian villages, NE, M 21c; NE, $\mathrm{N} 20 \mathrm{a}$.

NW, N 22c, O 21, 22, P 22, Q 23.

$\mathrm{SW}, \mathrm{J} 4 \mathrm{c}, 5 \mathrm{a}, \mathrm{T} 3 \mathrm{~d}, \mathrm{~T} 4, \mathrm{BC} 7$, $\mathrm{B} 10, \mathrm{E} 16 \mathrm{c}, \mathrm{D} 13$ to $\mathrm{E} 10$, G $6 \mathrm{a}, \mathrm{G} 7, \mathrm{H} 7$ to $\mathrm{N} 1$.

Indian workshops, NE, B 20abc; SE, A 1a.

Ingleside, NW, H 21.

Inlet, see under Water.

Institute, Institution, see under Building.

Island, Alexander, SE, A 6 to C 8 .

Island, Anacostian, name on old maps to include Analostan and Alexander Ids.

Island, Analostan, SW, T 3, 4; SE, A 3 to 5 .

Barbadoes-an old name for Analostan Id.

Island, Bear, NW, AB 14.

Island, Box Elder-Sycamore Id., NW, M 18.

Island, Conn, NW, A 11.

Island, Cupids Bower, NW, B $14,15$.

Island, Feeder Dam, NE, M 19.

Island, Herzog, NW, A 8. See also Turkey Id.

Island, High, NW, N 20.

Island, Holmes-A 1 e $\mathrm{x}$ a $\mathrm{n}$ d e $\mathrm{r}$ Island.

Island, Jacksons. See Scott Id. 
Island, Larkspur, NW, LM 17, 18.

Island, Lock, NW, A 8.

Island, Low, NW, N 19c.

Island, Masons-Analostan Id.

Island, Midriver, NW, A 8, 9.

Island, Minnies, NW, JK 16.

Island, My Lord's-Analostan Id.

Island, Perrys, NW, D $16 \mathrm{a}$.

Island, Plummers, NW, H 16.

Island, Powhatan, NW, A 9.

Island, Ripps. An island in the mouth of Tiber Creek, at about SE, C 4c.

Island, Scott, also called Jacksons, NW, E 16.

Island, Sycamore, NW, M 18.

Island, Sugar Maple, NW, L 17.

Islands, The Three Sisters, SW, RS 2.

Island, Trammel, NW, AB 9.

Island, Turkey or Hergozs, NW, D $15,16$.

Island, Woodchuck, probably the same as High Island.

Ivy City, SE, I 1.

Ivy City Sta. (Ward), SE, I 2. J.

Jackson, NW, D 19.

Jackson City Sta., SE, B $7 \mathrm{~b}$.

Jefferson Pier, was at SE, C 4c.

Jewel, or Jewells, SW, M 2.

Jones Corners, NW, D 20. $\mathrm{K}$.

Kalorama, SE, A 1b-2a.

Kalorama Heights, NE, AB 2, 3.

Kearney, SW, L 6.

Kendall Green, SE, GH 2.

Kengla's Woods, NW, R 23, along Foundry Branch.

Kenilworth, SE, N 1, 2.

Kensington, NW, S 8, 9.

Key of Keys or Quay of Quays old wharf at SE, B 4.

Kidwell Meadows, old name for northern part of Potomac Park.

Kirk Gold Mine, NW, B 9.

Klingle Ford, NE, B 21c.

Knowles Sta. and P. O.-Kensington, NW, S 8,9 .

L.

Laboratory, see under Building.

Lacey, SW, O 5c.

Lake, see under Water.

Lakeland, NE, O 14.

Lamond, NE, F 16.

Landover, NE, R 21, 22.

Lane, see under Road.
Langdon, NE, J 22, 23.

Langley, NW, J 19.

Lanier Heights, NE, B 22, 23.

Le Droit Park, NE, EF 23.

Leeland, NW, J 10.

Leesboro, NE, B 4a.

Lewinsville, NW, F 22.

Lewiston, NE, K 8 .

Libby Park, NE, F 20a.

Library, see under Building.

Licking Banks, SE, L 1.

Lincoln Banks (properly called Licking Banks).

Lincoln, SW, O 4 a.

Lincolnia, SW, LM 14.

Lincolnia Sta., SW, M 16.

Lincolnsville, NW, M 22a.

Linden, NE, B 11.

Linwood, SE, O 4.

Little Italy, SW, P 1d.

Livingston Heights, SW, N 3.

Lloyd, SW, T 13.

Lock, 5, 6, NW, N 20; 7, NW, L $17 ; 8$ NW, J $16 ; 9,10,11$, NW, I $16 ; 12,13,14, \mathrm{NW}$, H $16 ; 15,16$, NW. A $13 ; 17$, $18,19,20, \mathrm{NW}, \mathrm{A} 12$.

Lock, First (Ward)-Lock No. 5. Lock, Oak Spring, NW, A 8.

Lock, Outlet (Ward), SW, S 2.

Lock, Second (Ward et al.)Lock 6.

Lock, Stop, NW, A 13a.

Long Branch Sta., SW, I 21 .

Long Meadơws, SE, K 2.

Luna Park, SE, A 10.

Lunt, SW, M 17.

Lyonhurst, SW, N 2.

Lyttonsville, NE, A 12.

$$
\text { M. }
$$

Mackey, SW, S 3a.

McClellan Gate (Arlington National Cemetery), SW, T 6.

McLean, NW, H 21.

Madeley, NW, B 17c.

Magazine, see under Building.

Magruder-Tuxedo.

Mahoneyville, SW, R 16a.

Marsh, see under Water.

Marshall, SE, O 5.

Maryland Park, SE, Q 4, 5.

Masons Ferry, was at SE, A 4.

Massachusetts Avenue Terrace, NW, R 21.

Matildaville, old narne for rreat Falls village (Va.).

Mayhew's Meadows, SE, J 4.

Maywood, SW, P 3d.

Meridian Hill, NE, ડ̃D 22, 23. 
Merrifield, SW, C 6 .

Metropolis View, NE, GH 22.

Milburn, NW, F 11.

Milkhouse Ford, NE, B 17.

Mill, see under Building.

Millbrook-Lower part of Alex. andria Reservoir.

Mills Crossroads--Merrifield.

Mintwood Bank, Ni, B 23a.

Mintwood Place, NE, $3323 \mathrm{~b}$.

Mistletoe Valley (Ward), along Quarry Road NE, CB 22.

Mitchells Crossroads-Wheaton.

Monastery, NE, I 21.

Monteith, NE, T 6.

Montello, NE, I 23.

Montrose, NW, O 5a.

Monument, see undir Building.

Morningside, NW, $\mathrm{H}$ 11c.

Moor P. O., SW, H 20b.

Morven Heights, SW, R 11b.

Mount (elevation), see under Hill.

Mt. Ida, SW, T 13; SE, A 13.

Mt. Pleasant, SW, J 12.

Mt. Pleasant (Ward), NE, EF 22.

Mt. Pleasant proper was between the Old Piney Branch Road, the Fourteenth St. Road and Park Road, NE, CD 21.

Mt. Pleasant Village (Hopkins)-Piney Branch Park.

Mt. Pleasant Village (Ward), NE, CD 21.

Mt. Ranier, NE, KL 20.

Mt. Vernon Junction, SE, A 7.

Muirkirk, NE, S 3 to 4 .

Mulhall, SW, N 6 a.

Museum, see under Building. N.

Nacochtanke, the Indian village, occupied eastern shore of Eastern Branch from Bladensburg to mouth.

Namaraughquena, Indian village was at south end of Long Bridge, SW, B 7.

National Fair Grounds, NE, GH 23 ; SE, HI 1.

Nauck, or Nauck Springs, SW, R 10.

National Guard Rifle Range, SE, I 11.

New Alexandria, SE, A 19.

New Glatz, SE, FG 20.

Niles Crossroads, SW, JK 7.

Nork-misspelling of Nauck.

Normans Stone, NE, A 22c, 23a.
North Braddock, SW, T 14b.

North Rosemont, SE, A 15a.

North Takoma, NE, E 14, 15.

Notley Hall, SE, E 20.

No. 10, NW, J 15.

0 .

Oakland, SE, Q 8.

Oak Lane, NW, L 11d.

Oaks, SE, B 22.

Oak View-West Cleveland Park.

Observatory, see under Building.

Office, see under Building.

Offutts Crossroads-P o t o m a c, NW, E 9.

Orchard View, NE, P 8.

Overbrook, NW, E 11a.

Oxon, SE, I 17a.

Oxen Hill P. O. (Ward), SE, I 17.

$P$.

Pagetts Corners, SE, O 18.

Palisades of the Potomac-the rocky Virginia bluff above Georgetown.

Palisades of the Potomac (real estate subdivision), NW, $\mathbf{Q}$ 23.

\section{PARK.}

Circle, Dahlgren, NE, H 23b.

Circle, Dupont, SE, B 1, 2.

Circle, Grant, NE, E 20.

Circle, Iowa, SE, D 1, 2.

Circle, Scott, SE, C 2b.

Circle, Thomas, SE, D 2c.

Circle, Washington, SE, B 2, 3.

Garden, Botanic, SE, F 4c.

Lot, White, Circle, Ellipse or Oval, SE, C $4 \mathrm{~b}$.

Mall, The, SE, F to A 4.

Monument Grounds, SE, C 4.

Park, Bethesda, NW, Q 15b.

Park, Brightwood Driving, NE, CD 18.

Park, Folger, SE, G 5a.

Park, Garfield, SE, FG 5.

Park, George Washington, sw, T $16 \mathrm{a}$.

Park, Judiciary, SE, E 3d.

Park, Lincoln, SE, H 4d.

Park, McMillan, NE, EF 22, 23.

Park, Marion, SE, G 5d

Park, Montrose, SE, A 1

Park, National-Rock Creek Park

Park, Potomac, SE, A 4 to E 9.

Park, Mount Vernon, SE, E 2, 3.

Park, National Zoological, NE, B 22 . 


\section{Park-Continued.}

Park, President's-G r o u n d s surrounding Executive Mansion plus the White House Circle.

Park, Rawlins, SE, BC 3.

Park, Rock Creek, NE, BC 13 to 22 .

Park, Seaton, SE, E 4d.

Park, Smithsonian, SE, DE 4.

Park, Stanton, SE, G 4 b.

Park, Washington-g r o u n d s surrounding Wash ing to n Monument.

Park, Washington Driving, SE, LM 2, 3 .

Park, Zoological, NE, AB 21, 22.

Place, Seward, SE, G 5b.

Square, Farragut, SE, C 3a.

Square, Franklin, SE, C 3a.

Square, Lafayette, SE, C 3b.

Square, McPherson, SE, C 3b.

Park Lane, SW, R 3.

Park Woods, NE, E 23.

Pattersons Woods, SE, H 1c, d.

Peacock, NW, A 16.

Pennsylvania \&ivenue Heights, SE, KL 7, 8.

Penrose, SW, R 7.

Petersburg, SE, C 14, 15.

Petworth, NE, E 20.

Peyton, SW, R 9c.

Phelps Corner, SE, J 16.

Pierce, SW, R 3c.

Pinehurst, NW, T $16 \mathrm{~d}$.

Piney Branch Park, NE, D 19.

Pinnatifida Bluff-Eagle Rocl, $\mathrm{NW}, \mathrm{H}$ 16c.

Place, see under Park.

Pleasant Grove (Ward)-Glenville.

Pleasant Plains (Hopkins), NE, D 22.

Point, Arsenal-G r e e n l e a f's Point.

Point, Berry, SE, D 18b.

Point, Buzzard, or Turkey Buzzard, SE, F 8 .

Point, Easbys, SE, A 4. In earlier times called Cedar, Windmill and Peters Point.

Point, Giesboro, SE, E 10.

Point, Gravelly, SE, C 7 .

Point, Greenleafs, SE. E 8.

Point, Hunters, SE, C 10.

Point, Indian Queen, SE, DE 23.

Point, Jones, SE, C 18.
Point, Lumley, SE, B 17a.

Point, Marbury, SE, D 14, 15.

Point, Poplar, SE, G 8.

Point, Shepherd, SE, D 15.

Point, Sycamore, SE, A 6.

Point, Youngs-Greenleafs Point.

Point, West, SE, B 15c.

Pond, see under Water.

Pool, see under Water.

Poplar Bottom (Ward), NE, B $20,21$.

Potomac, NW, F 9.

Potomac Boat Club Landing, SW, R 2d.

Potomac City, SE, G 8.

Potomac Flats, SE, AB 4 to E 9 , also used for territory known as Alexanders Island on Virginia side of Potomac.

Potomac Yard, SE, B 11 to 13.

Promontory (Holm), probably equals Wintergreen Ridge, NE, B 19d.

Prospect Hill, NE, G 23b.

Prospect Hill, Electric Railway Station, NW, B 18.

Prospect Rock, NW, D 16a.

Pulpit Rock (Coues), probably at NE, B $20 \mathrm{~b}$, possibly NE, B 19d.

Q.

Queens Chapel, NE, T 4.

Queenstown (Ward), SE, G 20.

Queenstown Sta. was at NE, H $21 a$.

R.

Race, see under Water.

Radio, SW, S 7.

Radnor Heights, SW, S 4.

Railroad, Alexandria and Fredericksburg-Richmond, Fredericksburg and $\mathrm{Pot}$ om a c Railroad.

Railroad, Baltimore and Ohio, Freight, NW, T 12 to Q 23; SW, Q 1 to T 2 .

Railroad, Baltimore and OhioAlexandria or Shepherd's Landing Branch-NE, N 18 to $O 23$; SE. O 1 to D 15 .

Railroad, Baltimore and OhioMetropolitan Branch-NW, $\mathrm{L} 1$ to $\mathrm{T} 9$; NE, A 9 to $\mathrm{G} 23$; $\mathrm{SE}, \mathrm{G} 1$ to $\mathrm{F} 3$.

Railroad, Baltimore and OhioNew York Branch-NE, T 2 to I $23 ; \mathrm{SE}$, I 1 to $\mathrm{F} 3$. 
Railroad, Baltimore and Potomac-Baltimore and Ohio R. R., Shepherds Landing Branch in part, and Pennsylvania Railroad in part.

Railroad, Chesapeake Beach, SE, $\mathrm{M} 3$ to $\mathrm{T} 5$.

Railroad, Chesapeake and Ohio, $\mathrm{SE}, \mathrm{D} 5$ to $\mathrm{A} 16$; SW, T 16 to $\mathrm{A} 17$.

Railroad, Loudoun and Hampshire-Washington and Old Dominion Electric Railway, Bluemont Division.

Railroad, Orange and Alexandria-Washington Southern.

Railroad, Pennsylvania, NE, I 23 to $\mathrm{T} 19 ; \mathrm{SE}, \mathrm{N}$ to $\mathrm{P} 1, \mathrm{I} 1$ to $\mathrm{F} 3$.

Railroad, Pennsylvania (Rosslyn Branch), SW, T 3 to 5 ; SE, A 5 to $B$.

Railroad, Pennsylvania (through Freight Line) NE, T 19 to $\mathrm{P} 23$; SE, $\mathrm{P} 1$ to $\mathrm{D} 5$.

Railroad Station, Baltimore and Ohio was at SE, F 3, 4, Cor. N. J. Ave. and C St.

Railroad Station, Pennsylvania, was at SE, E $4 \mathrm{c}$.

Railroad, Virginia MidlandWashington Southern.

Railroad, W a s h ing to $\mathrm{n}$ and Ohio-Alexandria and Bluemont Electric Railway.

Railroad, Washington and Round Hill, Branch of SouthernWashington and Old Dominion Electric Railway, Alexandria and Bluemont Branch.

Railroad, Washington City, Virginia Midland and Great Western - W a s h ing t o n Southern R. R.

Railroad, Washington Southern, SW, A 17 to T 16 ; SE, A 16 to $\mathrm{D} 5$.

Station, Union (Alexandria), SW, T 16.

Station, Union (Washington), SE, FG 3.

Washington and Ohio Junctionsouthern part of Potomar Yard.

Railway, Arlington Electric, SW, T 3 to $\mathrm{R} 10$.

Railway, Bladensburg Electric, $\mathrm{SE}, \mathrm{I} 3$ to $\mathrm{J} 1$; NE, J 23 to P 13.
Railway, Cabin John Electric, NW, K 16 to Q 23.

Railway, Chevy Chase Electric, was from NW, $\mathbf{Q} 18 \mathrm{c}$ to $\mathbf{M}$ $18 \mathrm{~b}$.

Railway, City and Suburban Electric (Laurel Line), NE, T 2 to $\mathrm{G} 23$.

Railway, Georgetown and Rockville, NW, L 1 to $\mathrm{S} 23$.

Railway, Glen Echo Electric, formerly ran from Chevy Chase Circle to Glen Echo Heights.

Railway, Kensington Electric, NW, S 7 to 13 .

Railway, Washington, Alexandria and Mt. Vernon Electric - Washington - Virginia (Mt. Vernon Branch).

Railway, Washington and Great Falls Electric, NW, A 12 to T 23.

Railway, Washington and old Dominion Electric-Alexandria Branch Branch, SW, M 7 to $\mathrm{T} 12$; SE, A 12 to C 15 ; Bluemont Line, SW, A 3 to T 2.

Railway, Washington and Old Dominion ( $\mathrm{Gr}$ e at $\mathrm{F}$ alls Route), NW, A 13 to K 23; $\mathrm{SW}, \mathrm{K} 1$ to $\mathrm{T} 2$.

Railway, Washington, Arlington and Fairfax Courthouse Electric-Arlington Electric Railway.

Railway, Washington, Arlington and Falls Church ElectricWashington, Virginia, Falls Church Line.

Railway, Washington, Baltimore and Annapolis Electric, NE, $\mathrm{T} 22,23$; SE, $\mathrm{T} 1$ to $\mathrm{D} 3$.

Railway, Washington-Virginia Electric-Arlington Junction to Clarendon-SE, A 8 to 7; SW, T 7 to $\mathbf{Q} 5$.

Railway, Washington - Virginia Electric-Arlington Branch -SW, T 3 to 7 ; SE, A 7, 8.

Railway, Washington-Virginia Electric-Falls Church Line -SW, A 3 to T 7.

Railway, Washington-Virginia Electric-Hatfield-Green Valley Branch-SW, T 3 to $\mathbf{R}$ 10. 
Railway, Washington - Virginia -Mt. Vernon Branch-SE, D 5 to A 13, A 14 to B 23; SW, T 13, 14 .

Randle Highlands, SE, J 7.

Randolph, NW, 05.

Ravensworth, SW, B 17.

Redoubt, see under Fort.

Relee, SE, A 7c.

Reno, NW, S 18, 19.

Reservoir, see under Water.

Rester Bluff, SE, D 21.

Richmond Park, NW, T 21.

Riley, NW, M 17.

River, see under Water.

Riverdale, NE, No 17.

River Road (Settlement), NW, GH 11, 12.

River View, NW, N 19.

Rives, NE, L 21c.

Rixey, SW, M 2.

ROAD.

Avenue, Alabama, new name for Bowen Road.

Avenue, Blagden, NE, B 20 to C 19 .

Avenue, Central, SE, $\mathrm{N}$ to $\mathrm{T} 4$.

Avenue, Connecticut, NW, S 16 to $\mathrm{T} 19$; NE, A 20 to B 23 ; SE, A 1 to I 5 .

Avenue, Florida, NE, DE 23; $\mathrm{SW}, \mathrm{E} 1$ to I 3.

Avenue, Georgia, NE, D 14 to E 23.

Avenue, Kenesaw, NE, C 22.

A venue, Lincoln-L i n c o l n Road.

Avenue, Magnolia-Shepherd Road.

Avenue, Massachusetts, NW, $\mathrm{R} 21$ to $\mathrm{T} 23$; NE, A 23 .

Avenue, Michigan, NE, E 22 to $\mathrm{H} 21$.

Avenue, Minnesota, new name for Anacostia Road.

Avenue, Nebraska, NW, R 21 to $\mathrm{S} 19$.

Avenue, New York, SE, B 4 to $\mathrm{G} 1$.

Avenue, Nichols, SE, H 7 to G 12 .

Avenue, Oregon, new name for northern Military Road, NE, A to D 17.

Avenue, Pennsylvania, SE, A 2 to $\mathrm{L} 8$

Avenue, Sheridan, SE, H 8, 9.

Avenue, Sligo (wrongly named Blair Road), D 13 to $\mathrm{H} 12$.
Road-Continued.

Avenue, Stanton, SE, H 8 to I 10.

Avenue, Virginia, SE, A 3 to $\mathrm{H} 6$.

Avenue, Washington, SW, Q to S 7.

Drive, Beach, NE, B 14 to 20.

Drive, Ross, NE, B 17 to 19 .

Highway, Kings, SW, S 16 to R 23 .

Lane, Carters, NE, O to Q 18.

Lane, Cedar, NW, Q 12 to T 10.

Lane, Bradley, NW, 0 1.t to S 15.

Lane, Fern Spring, SW, P 1.

Lane, Leonards, SW, F 3 to G 1 .

Lane, Lovers, SE, A 1.

Lane, Magnolia, NE, B 22.

Lane, Magnolia-S h e p h e r d Road.

Lane, Woodley equals Woodley Road.

Road, Accotink, SW, T 19, 20; SE, A 23 to 18 .

Road, Adams Mill, NE, B 22.

Road, Anacostia, SE, 17 to $\mathrm{N}$ 1 ; NE, N 23 to $\mathrm{O} 21$.

Road, Annapolis, NE, N 20 to T 18.

Road, Annapolis (Ward), NE, G 2 to $\mathrm{T} 6$.

Road, Old Annapolis, NE, B 4 to $\mathrm{L} 1$.

Road, Aqueduct $-\mathrm{C}$ on d u it Road.

Road, Back Lick, SW, F 12 to G 23.

Road, Ballston, SW, T 3 to $\mathrm{K} 7$.

Road, Bates (Ward), F 19 to H 20 .

Road, Belt, NW, S 17 to 19.

Road, Benning, SE, I 3 to 07.

Road, Bladensburg, NE, M 20 to $\mathrm{J} 23$; SE, J 1 to I 3 .

Road, Bladensburg, NE, F 9 to I 14.

Road, Blagden Mill, NE, BC 19.

Road, Blair, NE, D 13 to F 18.

Road, Bowen, SE, L 8 to 07 .

Road, Braddock, SW, A 15 to F 12.

Road, Brandywine, SE, M 12 to $\mathbf{R} 23$.

Road, Brentwood ( W a r d ). mostly obliterated, NE, K 21 to $\mathrm{H} 23 ; \mathrm{SE}, \mathrm{H} 1$. 


\section{Road-Continued.}

Road, Brightwood (Ward), a bridle path, NE, D to A 17.

Road, Broad Branch, NW, T 16,17 ; NE, A 18 to $\mathrm{B} 20$.

Road, Brookville, NW, S 1 to T 2; NE, A 2 to D 17.

Road, Brookville (Ward), NW, $\mathrm{S} 16$ to $\mathrm{T} 7 ; \mathrm{NE}, \mathrm{A} 11$ and A 7 to $\mathrm{B} 6$.

Road, Bunker Hill, NE, F 22 to $\mathrm{L} 20$.

Road, Canal, NW, 022 to $\mathrm{Q}$ 23; SW, Q 1 to T 2.

Road, Carmody, SE, S 3 to P 4.

Road, Carroll, NE, EF 15.

Road, Chain Bridge, NW, Q 21 to 23 .

Road, Chappell, NW, T 18.

Road, Colesville, NE, G 2 to N 17.

Road, Columbia, NE, B 23 to E 22.

Road, Columbia, NE, L 1 to $\mathrm{H} 6$.

Road, Columbia, an old name for Bladensburg Road.

Road, Columpla, SW, I 13 to $\mathrm{T} 7$; SE, A 7, 8 .

Road, Conduit, NW, A 12 to Q $23 ; \mathrm{SW}, \mathrm{Q} 1$ to $\mathrm{S} 2$.

Road, Contee, NE, P to R 1 .

Road, Cool Spring, SE, J 3, 4.

Road, Daniel, NE, B 15 to A 17.

Road, Dickeys, NW, A 13.

Road, Eastern Branch-Anacostia Road.

Road, Edsall, SW, G 16 to $\mathrm{N}$ 15.

Road, Fairfax, SW, A 20 to S 16.

Road, Fairfax, SW, A 7 to I 6.

Road, Falls, NW, J 1 to A 12.

Road, Falls Church, SW, T 3 to I 5 .

Road, Falls Church and Fairfax, SW, A 7 to I 5 .

Road, Ferry. Old name for road from site of Anacostia Bridge through Bowen Road to Marlboro Road.

Road, Foxall or Foxhall, SW, $\mathrm{R} 1$ to $\mathrm{S} 2$.

Road, Foxhall (Ward)-Foxhall Road plus Ridge Road.

Road, Furnace, NE, S 1 to 3.

Road, Gallows, SW, D 1 to G 12.
Road-Continued.

Road, Georgetown-Columbia Road (in city).

Road, Georgetown and Rockville, NW, K 1 to $\mathrm{T} 23 ; \mathrm{SW}$, T $1,2$.

Road, Georgetown and Rockville (old), NW, N 5 to Q 14 .

Road, Giesboro, SE, G 22 to F 12.

Road, Good Hope, SE, H 7 to T 14.

Road, Good Luck, NE, P 16 to $\mathrm{T} 15$.

Road, Grant, NW, R 19.

Road, Gravel, SW, N 21 to T 18.

Road, Great Falls, SW, I 5 to G 1; NW, G 23 to C 17.

Road, Guinea, SW, B 12 to 15

Road, Hamilton, SE, I 8 to E 15.

Road, Harewood, NE, F 20 to G 21 .

Road, Hickey, NE, K 23.

Road, Highland, NW, $\mathbf{Q}$ to $T$ 12; NE, A 12 to C 10.

Road, Hunter, SW, D 1 to A 6.

Road, Kirby, NW, J 23 to $\mathrm{M}$ 20 ; SW, H 2 to J 1.

Road, Klingle, NE, A 22 to B 21.

Road, Leesburg, NW, A 14 to 022.

Road, Leesburg-L e e s b u r g Turnpike.

Road, Lincoln, NE, G 22, 23.

Road, Linnaean Hill, formerly connected Park Road with Pierce Mill Road, NE, B 20, 21.

Road, Little Falls, NW, O to R 21.

Road, Little River, SW, A 11 to $\mathrm{T} 16$.

Road, Livingston, SE, F 12 to $\mathrm{H} 16$.

Road, Lock, NW, A 7.

Road, Loughboro (Ward), NW, $\mathrm{S} 20$ to $\mathrm{P} 22$, in part $\mathrm{Ne}-$ braska Avenue, in part Little Falls Road.

Road, Magazine, SE, EF 13.

Road, Marlboro, SE, O 7 to $\mathrm{T}$ 10.

Road, Marlboro ( W a r d ) Walker Road.

Road, Merrifield, SW, C 4 to 6 . 


\section{Road-Continued.}

Road, Metzrott, NE, J 11 to 13. Road, Military, NW, T 19, NE, A 18, 19.

Road, Military, NE, A to D 17.

Road, Moreland-Rock Creek Ford Road.

Road, Morris, SE, H 8 to I 9.

Road, Murdock Mill, NW, QR 19.

Road, Naylor, SE, J 7, 8.

Road, New Cut, NW, D 1 to B 8 .

Road, New Cut, NW, L 11 to $\mathrm{K} 13$.

Road, New Cut, NW, Q 23; SW, Q 1 to $\mathrm{T} 1$.

Road, New Cut, NE, K 18 to L 17.

Road, Nourse, NW, ST 21; NE, A 21.

Road, Orndorff Mill (Ward), $\mathrm{NW}, \mathrm{J}$ to $\mathrm{N} 9$.

Road, Park, NE, B to D 21.

Road, Pierce Mill, NW, RST 20 ; NE, A 20 to B 21.

Road, Piney Branch, NE, E 15 to $\mathrm{C} 20$.

Road, Piney Meeting House, NW, AB 1.

Road, Piscataway, SE, I 23 to Q 16.

Road, Piscataway, SE, O 23 to T 21.

Road, Potomac, NW, E 10 to I 16.

Road, Powder Mill, NE, N 5 to $\mathrm{J} 9$.

Road, Quarry, NE, CB 22.

Road, Queens Chapel, NE, I 16 to $\mathrm{J} 23$.

Road, Rappley, NE, D 16 to H 12.

Road, Reno, NW, S 17, 18, formerly extended through $\mathrm{T}$ 19, 21, and NE, A 21.

Road, Ridge, an old name for Bowen Road.

Road, Ridge, NE, A 17 to B 19.

Road, Ridge, NW, Q 21 to $R$ 23 ; SW, R 1.

Road, Ridge, SE, L 4 to $\mathrm{N} 7$.

Road, Riggs, NE, F 18 to J 13.

Road, River, NW, A 6 to S 19 .

Road, River, SW, T 3 to 11; SE, A 11 to 15 .

Road, Rock Creek Church, NE, E 21 to F 19.
Road-Continued.

Road, Rock Creek Ford, NW, T 16; NE, A 16 to 18 .

Road, Rock Creek Ford (G. M. Hopkins), NE, B to D 18.

Road, Rockville-Georgetown and Rockville Road.

Road, Rockville (Ward), NW, $\mathrm{L} 1$ to $\mathrm{T} 6$; NE, A 6 to $\mathrm{B} 7$.

Road, Rolling, SW, A 17 to D 23.

Road, Sandy Spring (Ward), NE, F 16 to J 11.

Road, Sargent, NE, I 16 to $\mathrm{H}$ 20.

Road, Seven Locks, NW, J 2 to 15 .

Road, Seventh Street (Ward) -Georgia Avenue.

Road, Seventh Street (old name in Georgetown), SW, $\mathrm{R}$ to $\mathrm{T} 1$.

Road, Shepherd, NE, D 17 to F 18.

Road, Sheriff, SE, M 2 to $\mathrm{T} 1$.

Road, Sligo Mill, NE, H 15 to F 17.

Road, Spring, NE, CD 21.

Road, Suitland (Ward), SE, $\mathrm{K} 8$ to $\mathrm{O} 10$.

Road, Swart-Rock Creek Ford Road.

Road, Telegraph, SW, L 23 to S 16.

Road, Temple, SE, M 13 to $\mathrm{P}$ 23.

Road, Tunlaw, NW, R 21 to S 23 ; SW, S 1.

Road, Upper Marlboro, SE, Q 16 to $\mathrm{T} 14$.

Road, Walker, SE, J 8 to M 13.

Road, Wheeler, SE, G 10 to K 14.

Road, Windy Gap, SW, S 3ab.

Road, Woodley, NW, S 21 to T $22 ; \mathrm{NE}, \mathrm{A} 22$ to $\mathrm{B} 23$.

Street, Boundary, or Boundary-Florida Avenue, NE, DE 23; SW, E 1 to I 3.

Street, First s.e., Foot of, SE, F $7 \mathrm{~b}$.

Street, M Extended, SE, I to $\mathrm{K} 2$.

Street, Sixteenth, NE, C 18 to 23.

Street, Spring, NE, CD 21.

Turnpike, Alexandria \& Washington, SE, B 15 to 7 . 


\section{Road-Continued.}

Turnpike, Ashton and Colesville, NE, G 1 to $\mathrm{N} 14$.

Turnpike, Baltimore or Boulevard, NE, T 2 to $\mathrm{K} 21$.

Turnpike, Colesville, NE, D 13 to $\mathbf{G} 1$.

Turnpike, Georgetown-Leesburg Road.

Turnpike, Leesburg, NW, A 21 to $\mathrm{C} 23$; SW, C 1 to $\mathrm{T} 16$; SE, A to C 16.

Turnpike, Leesburg and Alexandria-Leesburg Turnpike.

Turnpike, Washington and Baltimore-Baltimore Boulevard.

Turnpike, Washington and Brookville-Brookville Road.

Turnpike, Washington and Marlborough - M a r l b o ro Road.

Robey, SW, F 4c.

Rock Creek P. O., was at NE, F $18 \mathrm{~d}$.

Rock Springs, NW, M 18.

Rockville, NW, JKL 1.

Rockwell, NW, K 23.

Rosedale, SE, I 4d.

Rosemont, SW, T 15; SE, A 15.

Rosiers Bluff-Indian $Q$ u e e $\mathbf{n}$ Point.

Rosslyn, SW, S 3.

Run, see under Water.

Rupperts Copse, SE, L 1a.

S.

St. Asaph-territory to east of present Mt. Ida station.

St. Elmo, SE, A 12.

Salona, old name for Langley.

Sandy Landing (on map), NW, B 9; (Wards) NW, A 14; (local name) NW, H 16.

Saul's Nursery, NE, D 19.

Sawpit Landing, SW, A 3a.

Scheutzen Park, NE, E 21, 22.

Scheutzen Park, SE, G 2a.

Scheutzen Park, Green Spring, SW, S $2 b$.

\section{SCHOOL.}

Academy, Holy Cross, NE, A 20.

Academy, LaSalle, NE, Q 5 .

College, Christian Brothers, NE, Q 5 .
School-Continued.

College, Columbia, old site of predecessor of George Washington University, Chapin St. to Columbia Road, 14th St. to University Place, NE, CD 22.

College, Gallaudet, SE, H 2.

College of Agriculture, Maryland State, NE, M 14.

College, Trinity, NE, G 22.

College, War, SE, E 8.

School, A, SW, P 13.

School, Blair, NE, G 11.

School, Bliss Electric, NE, E $14 \mathrm{c}$.

School, Camp Springs, SE, P 16.

School, Casper (misspelled

Carper), NW, C 17.

School, Dwyer, NW, S 1.

School, Edgewood, NE, P 3.

School, Episcopal High, SW, Q 13.

School, Forestville, SE, S 10.

School, Girls' Reform, NW, P 21.

School, Glen Echo, NW, L 15.

School, Groveton; SW, Q 21.

School, Hume, SW, T 8.

School, Jefferson, SW, T 8.

School, Kemper, SW, S 10.

School, Laurel Grove, SW, K 21.

School, Locust Grove, SE, N 18.

School, Montrose, NW, o 5.

School, National Training, for Boys, NE, KL 22.

School No. 2, SE, F 22.

School No. 8, SW, P 13.

School, Oak Grove, SE, S 1.

School, Odrick, NW, B 21.

School, Oxon Hill, SE, I 17.

School, Paint Branch, NE, N 9.

School, Pine Grove, SE, S 7.

School, Piney Grove, NE, Q 14.

School, Pohick, SW, B 23.

School, Racetrack, SW, G 11b.

School, Reform-N a t i o n a l

Training School for Boys.

School, Riggs, NE, I 15.

School, Scotland, NW, J 6.

School, Saegmuller, NW, N 22.

School, St. Barnabas, SE, K 14.

School, Suitland, SE, O 10.

School, Valley, SW, R 18. 


\section{School-Continued.}

School, Wakefield, SW, B 13.

School, Wayside, NW, G 5.

Seminary, Chevy Chase, NW, S 15.

Seminary, Episcopal Theological, SW, Q 14b.

Seminary, Fairfax-Theological Seminary.

Seminary, National Park, NE, A 10.

Seminary, Theological, SW, Q 14.

University, American, NW, R 21.

University, Catholic, NE, G 21.

University, Georgetown, SW, S 2.

University, Howard, NE, E 22.

Scotland, NW, J 6d.

Seat Pleasant, SE, T 4.

Seat Pleasant P. O., SE, Q 3.

Selva, NW, I 22.

Seminary, see under School.

Seminary Sta., SW, R 16.

Seven Locks, NW, H to J 16.

Sewage Farm (Takoma Park), a septic tank only, no farm, NE, H 15.

Shadyside, NW, K 11.

Shepherds Ferry, SE, D 14d.

Shepherd Landing, SE, D 15.

Shepherd Sta. (Ward), SE, E 11.

Sheridan Gate (Arlington National Cemetery), SW, T 5.

Silver Hill, SE, M 11.

Silver Spring, NE, DE 13.

Slashes (Coues), north of N St. between 14th and 21st, SE, BC 1, 2.

Sligo, NE, D 12.

Smithfield, NE, H 2.

Soapstone Quarry (Ward) is that at head of Soapstone Creek, NW, T 19d.

Soapstone Quarry and ruins of soapstone sawmill, NW, K $17 \mathrm{~b}$.

Somerset, formerly S. Heights, NW, Q 16.

Sonoma, NW, o 12.

South Arlington, used loosely for settlements south of Arlington P. O., to and including Cowden.

South End, SE, B 7b.

South Washington, SE, A 8.
South Washington (Steele)vicinity of James Creek Canal.

Spring, see under Water.

Springfield, SW, G 17.

Spring Hill, NW, C 18.

Spring Park-Union Station Sta., Alex., SE, A 16a; SW, T $15,16$.

Springvale, not on map, about one mile west of Elkins.

Square, see under Park.

Station, see under Railroad.

Stott, NE, G 18.

Street, see under Road.

Suitland, SE, O 10.

Summit, SW, N 2c.

Sunnyside, NE, Q 9 (R. R. Sta.); NE, P 8c (Electric Ry. Sta.).

Surrattsville-Clinton, SE, R 21. Swamp, see under Water.

Swimming Landing, NW, P 23a.

Syfax, SW, S 7d.

\section{T.}

Table Mountain Pine Woods (Ward), NE, A 19.

Talioma Park, NE, E to G 15.

Tavern, see under Building.

Tenallytown P. O.-Tenleytown.

Tenley or Tenley Town, NW, S 19.

Tenleytown Junction, NW, Q 18c.

Terra Cotta, NE, G 19.

Terrett Crossroads, SW, R 13.

The Triangle, NE, C 11.

Thrifton, SW, Q 3.

Tollgate, SW, G 4.

Torreyson (Torrison), SW, M 6.

Trinidad, SE, H 12.

Truxtun, NW, B 12.

Tunlaw Heights, NW, s 21d.

Turnpike, see under Road.

Tuxedo, NE, P 23.

Twining, SE, J 6, 7.

Tysons Crossroads (county seat Fairfax County, 1742-54), NW, BC 23.

U.

Ulles Crossing, NE, P 7.

Uniontown (Ward)-northeast. ern part of Anacostia.

University, see under School.

Upton, SW, L 5.

University Heights, NW, Q 20.

University Station (Catholic), NE, H 21. 
$\mathrm{V}$.

Valerian Bluff. Ward's name for a ridge on the north side of Rock Creek near the upper end of the Zoological Park. Polemonium reptans once abundant.

Vanderwerken, SW, M 1.

Vansville, NE, R 6 .

Veitch, SW, MN 6.

Vinson, SW, R 5 .

Viulet Ridge, NE, C 22c.

Violet Rock, SW, R 2d.

Viresco, NW, I 22.

Virginia Highlands, SE, A y

Virginia Manor, NE, S 3.

Vis-a-vis Landing, SE, S 2c. IV.

Waggaman Estate, NE, A 22, 23.

Walbridge Estate or Place, NE, BC 20, 21.

Walnut, SW, Q 4d, R 4a.

Warwick, SE, B 23.

Wasena Park, NE, O 19.

Washington Heights, SE, B 1, $\mathrm{NE}, \mathrm{B} 23$.

WATER.

Basin, Inner, SE, C 4c.

Basin, Lydecker-M c M i l l a n Park Reservoir.

Basin, Tidal, SE, BC 5.

Bay, Broad, SE, E 23.

Bog. This name should really be used for most of those here called "Swamps."

Bog, Suitland, SE, QR 11.

Branch, Barnaby, one of the small streams in the Soldiers' Home grounds.

Branch, Bear-Long Branch, SW, C 3 to A 9 .

Branch, Beaverdam, NE, T 20 to $\mathrm{P} 23$ and MN 23; SE, N to $\mathbf{Q} 1$.

Branch, Bogleys, NW, I 3 to K 5 .

Branch, Bowies (Ward), on map as Booze (probably a corruption) Creek, NW, O 13 to J 14.

Branch, Broad, NW, S 16 to T 18; NE, A 18 to B 20.

Branch, Bryan, NW, J 23 to 21.

Branch, Cabin, SE, QR 8 to P 1.

Branch, Carey, SE, I 17 to $\mathrm{H}$ 20.

Branch, Carroll, NW, C 12 to A 12 .
Water-Continued.

Branch, Cattail, NE, T 23 to R 22 .

Branch, Cool Spring, NW, C 11 to A 10.

Branch, Deep Cut, SW, G 19 to E 20 .

Branch, Eastern of the Potomac, NE, M 20 to 23 ; SE, $\mathrm{M} 1$ to $\mathrm{E} 9$. On older maps it includes Anacostia River plus Indian Creek.

Branch, Fenwick, NE, B 12 to C 14 .

Branch, Field Lark, SW, G 21 to 23 .

Branch, Foundry, NW, S 20 to $\mathrm{R} 23$; SW, R 1 to $\mathrm{S} 2$.

Branch, Greenbrier, NW, B 2 to A 4 .

Branch, Gulf, NW, M 23 to O 22.

Branch, Hunters Mill, SE, L 21 to $\mathrm{G} 22$.

Branch, Kilgour, NW, E 8 to D 6.

Branch, Laudanum, SW, F 17 to E 18.

Branch, Limekiln, NW, B to A 11.

Branch, Little Falls, NW, S 16 to 019.

Branch, Lockes, probably the same as Blagdens Run.

Branch, Long (Tributary to Accotink Creek, SW, B 4 to A 9.

Branch, Long (Tributary to Accotink Creek), SW, A 14 to $\mathrm{B} 15$.

Branch, Long (Tributary to Accotink (reek), SW, H 19 to 23 .

Branch, Long (Tributary to Fourmile Run), SW, $\mathbf{Q} 6$ to $\mathrm{T} 10$.

Branch, Long (Tributary to Sligo Branch), NE, F 10 to H 15.

Branch, Maddox, NW, Q 21 to P 23.

Branch, Naylors ( W a r d ), equals Minnehaha Creek, NW, O 14 to L 17.

Branch, North of Little Hunting Creek-Paul Spring Branch.

Branch, Northwest, NE, E 1 to $\mathrm{M} 20$. 
Water-Continued.

Branch, Northwestern of the Potomac, see North wes t Branch.

Branch, Paint. Some old maps apply this name to Indian Creek, leaving Little Paint Branch for what is now called Big Paint Branch.

Branch, Paint (Big), NE, G and $\mathrm{K} 2$ to $\mathrm{M} 20$.

Branch, Little Paint, NE, 01 to $\mathrm{N} 11$.

Branch, Paul Spring, or Pauls, tributary of Little Hunting Creek, SW, R 21 to $\mathrm{T} 22$; SE, A 22, 23.

Branch, Payne, SE, S 15 to Q 18 .

Branch, Pike, SW, 0 :0 to $\mathrm{S}$ 17.

Branch, Piney (Tributary to Rock (reek), NE, E 16 to B 21.

Branch, Piney (Tributary to

Watts Branch), NW, E 1 to C 6.

Branch, Reedy-Tiber Creek.

Branch, Sandy (Tributary of the Potomac River), NW, B 1 to A 2.

Branch, Sandy (Tributary of Watts Branch), NW, B 5 to A 6 .

Branch, Silver Spring, NE, D 13 to C 14.

Branch, Sligo, NE, B 6 to J 18.

Branch, Snakeden, NW, I 4 to J 7.

Branch, Soapstone-Soapstone Creek.

Branch, Southwest, SE, S 9 to $T 7$.

Branch, Spring, formerly ran from $\mathrm{SE}$, I $3 \mathrm{c}$ to $\mathrm{J} 4 \mathrm{c}$.

Branch, Stickfoot, SE, J 9 to G 8 .

Branch, Thomas, NW, M 9 to J 13.

Branch, Ubers, SW, I 7.

Branch, Watts, NW, H 1 to A 6 .

Branch, Watts (Ward), SE, Q 7 to L 2.

Branch, West, a name for Northwest Branch.

Branch, Willett, NW, Q 14 to $P 17$.

Brook, Lanier Heights, NE, B $22 \mathrm{~d}$.
Water-Continued.

Brook, Little Falls-Lit t le

Falls Branch.

Brook, Mintwood, NE, B 23a.

Brook, Mt. Pleasant, NE, C 21.

Brook, Pierces Mill, NE, AB 20.

Brook, Waterloo, SE, A 9 to B 10.

Canal, Chesapeake and Ohio, NW, A 7 to Q 23; SW, A 1 to $\mathrm{T} 2$.

Canal, C. \& O. (Old course through city) was from SE, A 3 (mouth of Rock Creek which fed canal) along river and $\mathrm{B}$ st. s.w., which it paralleled to E $4(61 / 2$ and B Sts. s.w.), turned south to position of West Capitol St., followed that to 3d St., turned south to E 4d (3d St. and Maryland Ave.), southeast along Canal St. to F 5d (E and South Capitol), thence by a southwesterly course still traceable by form of city blocks through James Creek to its mouth, SE, EF 8. A branch ran from $F$ 5d along Virginia Ave. to $2 d$ St. s.e., and down that to the river, SE, G $7 \mathrm{a}$.

Canal, C. \& O. In 1793 ended at Outlet Lock, mouth of Maddox Branch, NW, P 23.

Canal, James Creek, SE, F 6 to $\mathrm{E} 8$.

Canal, Potomac. The old course on Virginia side was from Aqueauct Bridge, SW, $\mathrm{S} 2$, through what is now A rlington Experimental Farm, west of Arlington Junction (SE, A 8) east of Addison, across Four-mile Run near mouth to about middle of present Alexandria river front.

Cascade, The (Ward) - fall at mouth of Gulf Branch.

Channel, Georgetown, SE, A 4 to $\mathrm{D} 9$.

Channel, Washington, SE, D 5 to $\mathrm{E} 9$.

Creek, Accotink, SW, A 9 to F 23 . 


\section{Water-Continued.}

Creek, Beaver Dam, NE, T 9 to $\mathrm{R} 10$.

Creek, Big or Great HuntingHunting Creek.

Creek, Booze (Bowies), NW, O 13 to J 14.

Creek, Broad, SE, FG 22, 23.

Creek, Cabin John, NW, K 1 to $\mathrm{L} 16$.

Creek, Dalecarlia-Little Falls or Falls Branch.

Creek, Dogue, SW, M 19 to N 23.

Creek, Goose-Tiber Creek.

Creek, Henson, SE, T 14 to G 23.

Creek, Hunting, SE, AB 17, 18, 19.

Creek, Indian, NE, S 2 to P 15.

Creek, James, originally St. James. Began where Li

- brary of Congress now is and ran to juncture of $\mathbf{S}$. Capitol and Canal Sts. (SE, FS 6), thence to what is named on our map James Creek Canal.

Creek, Little Hunting, see Paul Spring Branch.

Creek, Minnehaha, NW, O 14 to $\mathrm{L} 17$.

Creek, Piney (Ward), SE, P 2 to $M 1$.

Creek, Piscataway. Tributaries at SE, Q 22, 23, S 22 to $\mathrm{Q} 23$ and $\mathrm{T} 22,23$.

Creek, Pohick, SW, A 20 to C 23.

Creek, Rock, NW, $P 1$ to $T$ 10 ; NE, A $11,12, \mathrm{~A} 14$ to 23 ; $\mathrm{SE}, \mathrm{A} 1$ to 3 .

Creek, Soapstone, tributary to Broad Branch, NE, A 19 to B 20 .

Creek, Tiber or Tyber. Crossed Florida Ave. at 7 th St. N.E., E 23 (this part called Reedy Branch) to SE, F 2 (N. Y. Ave. and N. Capitol St.) to F 4 (Botanic Garden) where it entered the canal. The mouth was at $C 4$ (Tidal Basin). It received branches which crossed Florida Ave. at about $\mathrm{R}$ St., SE, F 1, New York Ave. (S. E. G 2), and at New Jersey Ave. and
Water-Continued.

D St. n.w. (F 3), a tributary arising at about $\mathrm{H}$ 3d. The Tiber, large near the mouth, as are all of the Coastal Plain Streams, once occupied a large part of what is now The Mall, from Botanic Garden to northern edge of Tidal Basin.

Creek, Tinkers, SE, S 17 to L 23.

Ditch, Brier, NE, T to P 16 .

Ditch, Funkstown, was in the old settlement Hamburgh.

Falls, Bullneck, NW, C 17ac.

Falls, Great, NW, A 12.

Falls, Little, NW, N 21.

Falls, Lower-Little Falls.

Falls, Matilda or Upper-Great Falls.

Falls, Scotts Run, NW, F 16 c.

Falls, Stubblefield, NW, F 16.

Falls, Triple, at mouth of Foundry Run.

Flow, Buttermilk-Dead Run.

Gut, Galway-Roaches Run.

Gut, Piney Run (Coues)course of Piney Run.

Gut, Succabels, SE, L 2, 3.

Gut, Turtle (Coues), SE, J 4.

Inlet, Roaches, mouth of Roaches Run.

Hole, Cat, NW, G 16c.

Lake, Chevy Chase, NW, S 13.

Marshes, Eastern Branch, NE, MN 20 to 23; SE, LM 1, 2.

Marsh, McCormicks (Coues), NE, N 23.

Pond, Black, NW, A 8, 9. The Pond at NW, BC 15, is better known by this name.

Pond, Brasenia, C a r b e r r y Meadows below Eads' Mill.

Ponds, $F^{*}$ sh, in part filled, in part now used as bathing pools, SW, C 4c.

Ponds, Shaws Lily, SE, M 1.

Pool, Nymphaea, NW, B 15b.

Race, SW, Q to T 16 ; for Hunt and Roberts Flour Mill, T $16 \mathrm{c}$.

Reservoir, SW, T 16.

Reservoir, Alexandria, SW, K 9 , J to L 10 , LM 11.

Reservoir, Dalecarlia, NW, OP 20. 


\section{Water-Continued.}

Reservoir, Distributing, SW, QR 1.

Reservoir, High St., SW, T $1 b$.

Reservoir, Howard Hill-McMillan Park Reservoir.

Reservoir, McMillan Park, NE, EF 22, 23.

Reservoir, New-M c Milla n Park Reservoir.

Reservoir, Receiving (Ward)Dalecarlia Reservoir.

Reservoir, Reno, NW, S 18c.

Reservoir, Sixteenth St., NE, C 18 .

River, Anacostia (Eastern Branch of the Potomac), NE, M 20 to 23 ; SE, M 1 to $\mathrm{E} 9$.

River, Little, SW, T 3 to 5 ; SE, A 4, 5 .

River, Potomac, NW, A 7 to $\mathrm{P} 23 ; \mathrm{SW}, \mathrm{P} 1$ to $\mathrm{T} 4$; $\mathrm{SE}$, A 3 to $\mathrm{B}$ to E 23 . Old names were: Indian, Cohonguroton: Spanish, Espiritu Santo; English, Pembrook, Patowomek, Patowmel.

Run, SW, O to Q 16. Seems to be race of Dominion Grist Mill at Q $16 \mathrm{~b}$.

Run, Aralia, NE, A 22, 23.

Run, Asarum, NE, A 20cd, B $20 \mathrm{c}$.

Run, Asplenium, is one of the small runs on the Virginia shore above Chain Bridge, so named for Asplenium angustifolium.

Run, Back Lick, SW, F 13 to O 16.

Run, Berry, NE, G 22.

Run, Blagden, NE, C 18 to $\mathrm{B}$ 20.

Run, Bullneck, NW, C 19 to D 16.

Run, Bulls, NW, N 9 to M 12 .

Run, Cameron, SW, O 16 to $\mathrm{T} 17$.

Run, Cascade (Ward), NE, AB 21.

Run, Cow-Lubber Run.

Run, Cystopteris, one of the small runs on Virginia shore below Chain Bridge.

Run, Dead, NW, G 21 to I 16.

Run, Dead Mans-Gulf Branch.

Run, Deep-Turkey Run.

Run, Deep-Foundry Run.

\section{Water-Continued.}

Run, Delaney, probably SW, G 6 to I 7.

Run, Difficult, NW, A 15 to B 15.

Run, Doctors, SW, P 6 to 10 .

Run, Donaldson, SW, $\mathrm{N} 2$ to O 1 ; NW, OP 23.

Run, Donaldsons, also applied to stream from SW, 02 to $P 1$.

Run, Flag, SW, E 15 to D 17.

Run, Found ry-F o u d r y Branch.

Run, Glen Echo-Minnehaha Creek.

Run, Gold-Bullneck Run.

Run, Goldianum (Ward), SW, PQ 2.

Run, Goldie, NW, J 17.

Run, Gravelly, upper channel Roaches Run, SE, A 6.

Run, Green Spring, SW, S 1, 2.

Run, Hickey, NE, I 22 to J 23 ; SE, J 1 to $\mathrm{K} 2$.

Run, Holmes, SW, D 3 to O 16.

Run, Hooff's, SW, A 14-17.

Run, Hydrophyllum (Knowlton), SW, O 2 to $\mathbf{Q} 1$.

Run, Indian, SW, G 13 to $\mathrm{K}$ 17.

Run, Little Pimmit, NW, L 23 to 21 ; SW, M 3 to $\mathrm{L} 1$.

Run, Lobelia, NE, A 22, 23.

Run, Lovers, a mistake for Lubber Run.

Run, Lubber, SW, N 4 to 8, so called on 1793 map.

Run, Lucky, SW, P 13 to Q 10.

Run, Magnolia, NE, C 22a.

Run, Middle, SW, A 23.

Run, Mill-Foundry Run.

Run, Mitella (Ward), NE, A $22,23$.

Run, Observatory, NW, T 22, 23 ; NE, A 23.

Fiun, old C. H. (Ward)-part of Wolftrap Run, NW, B 23 to A 22.

Run, Oxon, SE, Q 8 to E 15.

Run, Pawpaw, NW, C 16, 17.

Run, Pimmit, NW, $\mathrm{H} 23$ to $\mathrm{O}$ 22 ; SW, D 2 to $\mathrm{H} 1$.

Run, Piney, SE, Q 6 to L 3.

Run, Piney (Tributary to Dogue Creek), SW, M 21 to N 23.

Run, Prospect-Bullneck Run. 


\section{Water-Continued.}

Run, Rhododendron-Gulf $\mathrm{Br}$.

Run, Roaches (Ward), a tide channel formerly cutting off Alexander Id., SE, A 6 to B 8.

Run, Rock, NW, E 8 to I 16.

Run, Rock, name on old maps for Donaldsons Run.

Run, Rocket (Ward), NW, T 23 ; NE, A 1.

Run, Rocky, NW, B 22 to A 15.

Run, Scotts, NW, C 23 to F 16.

Run, Spout, SW, P 5 to R 3 .

Run, Talapaumin, NE, A 22, 23.

Run, Taylor, SW, R 13 to S 17 .

Run, Tipularia, SW, B 3a.

Run, Tripps, SW, F 4 to K 10.

Run, T u n law-Found ry Branch.

Run, Turkey, NW, J 20 to 17.

Run, Turkey Buzzard. Name on old map for upper Potomac, supposed to be a tributary of Anacostia River.

Run, Turkeycock, SW, I 12 to L 16.

Run, Waterloo, SE, T 20 to M 22.

Run, YYindy, SW, 03 to Q 2.

Run, Wolftrap, SW, C 2 to A 2 ; NW, B 23 to A 22.

Spring, Arlington, SE, A 6c.

Spring, Bladensburg, NE, N $20 \mathrm{~d}$.

Springs, Carlin, SW, N 8b.

Spring, Cold, NE, M 8 a.

Spring, Crystal, NE, C 18c.

Spring, Custis, SE, A 6a.

Spring, Fern, SW, P 1.

Spring, Gibsons (old name), SE, I 3c.

Spring, Hume, SE, A 11.

Spring, Indian, NE, F $9 \mathrm{~b}$.

Spring, Indian, NW, D 23c.

Spring, Miller Cabin, NE, B $17 \mathrm{~b}$.

Spring, Silver, NE, D 13d.

Spring, Table Mountain Pine, probably-Crystal Spring.

Spring, Takoma Park, NE, G $16 a$.

Spring, Wilson, SW, S 11b.

Spring, Woodley Bridge, NE, B 22c.
Water-Continued.

Spring (continued), NW, A 11a; A 12a; A 13 (between 2 houses shown outside boundary line); A 13d; A 14c; A 15c; B 15c; B 16a; C $15 \mathrm{c}$; D 16c; D 17b; D 23b, c; $E$ 16c, d; E 18b; F 16a, b; G $17 \mathrm{a}, \mathrm{b} ; \mathrm{H} 16 \mathrm{a}, \mathrm{b}, \mathrm{c}, \mathrm{d}$; I 16b; I 17a; I 21d; J 13d; $\mathrm{J} 16 \mathrm{a} ; \mathrm{J} 21 \mathrm{c} ; \mathrm{K}$ 11b; $\mathrm{K} 16 \mathrm{~b}$; L 18d; N 17a; N 20c; $\mathrm{N} 21 \mathrm{c} ; \mathrm{N} \mathrm{22b,d;} \mathrm{N} \mathrm{23d;O}$ $21 \mathrm{~b}$; O 22a, b; O 23a; P 14c; P 19d; P 22b; Q 21c; R 23d; T 19b; T 20d. NE, A 19b; A 20d; A 21b, c; A 23b; B 19a; B 20a; B 23c; C 14c; C 21a; G 14c, d; L 7c; M 7c; M 23c; N 16c; O 11b; O 19a; P 12d; P 18a. SW, G 6a; $\mathrm{H}$ 7c; H 8a; J 13d; L 6a; L 11a; M 1d; M 17a; N 6c; P 2c; Q 2c, d; S 3a, c. SE, A 1a; A 10b, c; A 17a, d; A $22 \mathrm{~b} ;$ B $17 \mathrm{c}$; B 22a, c; B 23c; F 11d; L 1a; N 7d.

Swamp, Bladensburg. This and the Hyattsville swamp are continuous.

Swamp, Brightwood Park, NE, E 18c; another at D 8c.

Swamp, Deanwood, SE, O 2.

Swamp, Fort Totten, NE, H 19.

Swamp, Gerardia, NE, M 20.

Swamp, Holmead, NE, C 21a.

Swamp, Hyattsville, NE, O 18, 19.

Swamp, Lygodium, or Riverdale, NE, R 18c.

Swamp, Magnolia, or Magnolia Run, NE, C 22a.

Swamps, Paint Branch, or Powder Mill, NE, M 7c (No. 1) ; M 8 a (No. 2 or Cold Spring); L 7d (No. 3), L 7c (No. 4).

Swamp, Phlox, NE, G 18d.

Swamp, Sarracenia, SE, M 1.

Swamp, Walbridge-Magnolia Run Swamp.

Swamp, Woodwardia-Hyattsville Swamp.

Water, Broad-Widewater.

Water, Wide, NW, B 14.

Waterloo Sta., SE, B 9c. 
Waycroft, SW, N 5 .

Wedderburn, SW, B 3.

Wesley Heights-vi c i n it y of American University.

West Chevy Chase, NW, R 16c.

West Falls Church, SW, GH 4.

West Highlands, NW, S 21b.

West View, NW, L 11.

West Washington-Georgetown.

Wheaton, NE, B 6.

Whitehouse, NE, P 9.

Whiteoak, NE, H 6.

Whites, NE, T 23.

Wildwood, NE, H 15 a.

Wildwood, NW, HI 11.

Wilen Heights, NE, K 21 b.

Wilson Sta.-Landover.
Windermere, NW, D 11.

Windham, NW, P 5 .

Windy Gap, SW, S 3b.

Wintergreen Ridge, NE, B 19d.

Winthrop Heights, NE, J 23.

Wiscasset, NW, M 17.

Woodford, SW, A 3.

Woodley (Ward), NE, A 22, 23; SE, A 1.

Woodley Park, NE, A 22.

Woodmont, SW, P 3d.

Woodmont, NW, Q 13.

Woodridge, NE, IJ 22.

Woodside, NE, CD 12.

Woodside Station, NE, C 12. Y.

Yarrow, NW, P 9. 


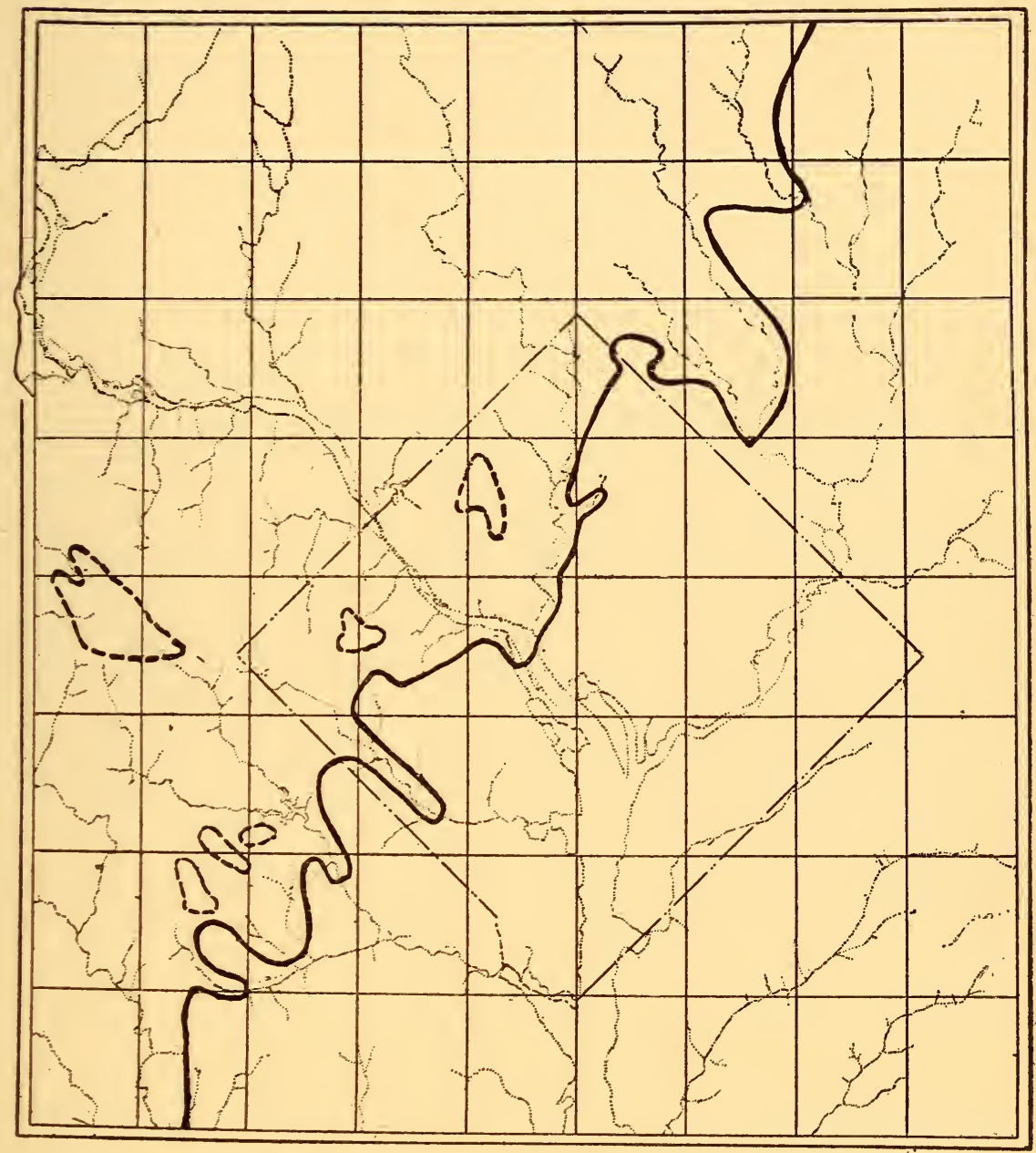

The Piedmont Plateau and the Coastal Plain in the vicinity of the District of Columbia. Solid heavy line indicates easternmost outcrops of the metamorphic rocks. Broken heavy lines show the positions of important isolated bodies of Coastal Plain Deposits. Stream courses are dotted. 



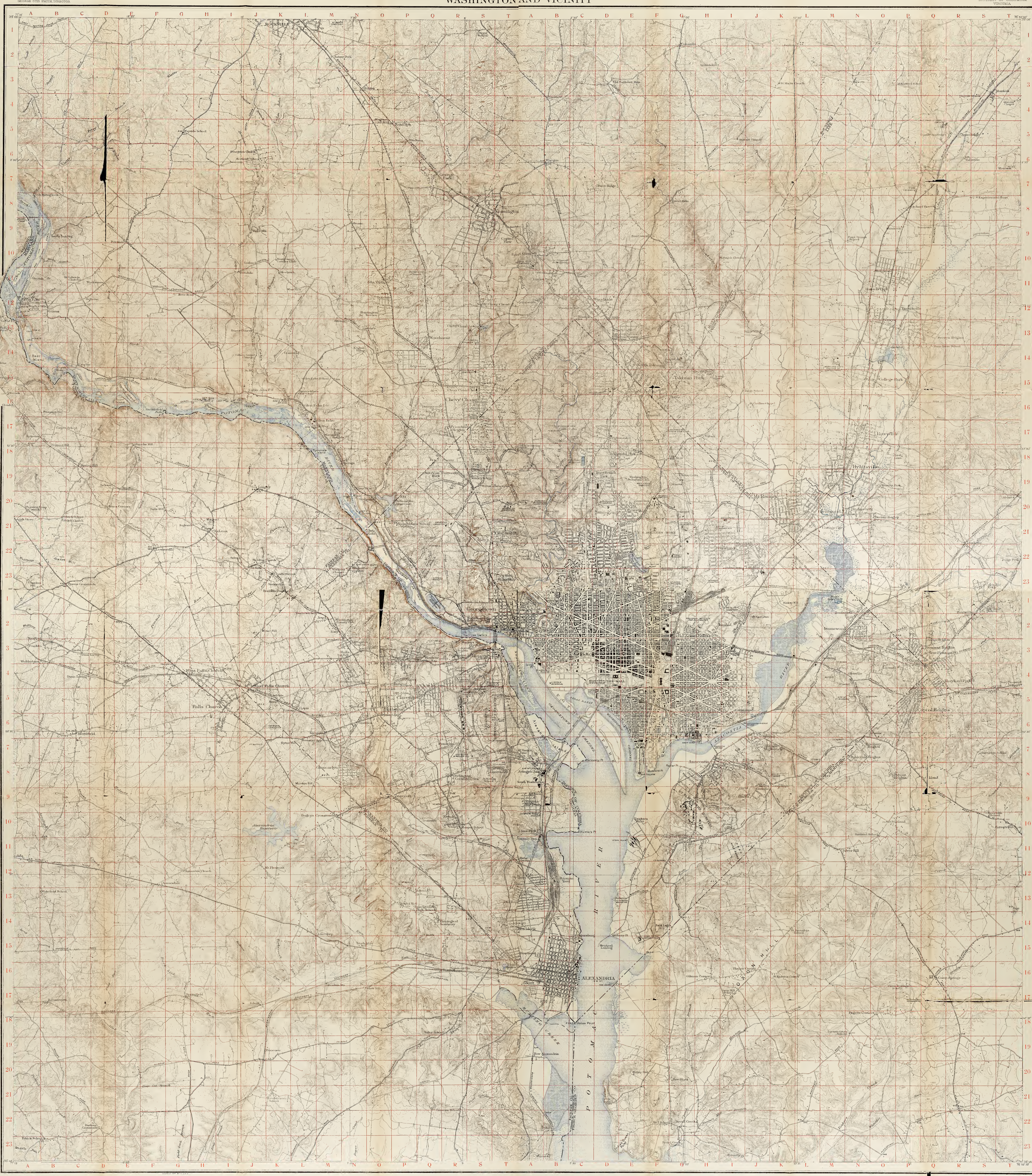




